\title{
FLUXOS DE PRODUÇÃO E CONSUMO DE MILHO NO SUL E SUDESTE DO BRASIL
}

\author{
VIVIANE VUOLO RISSETO
}

Dissertação apresentada à Escola
Superior de Agricultura "Luiz de
Queiroz", Universidade de São
Paulo, para obtenção do título de
Mestre em Ciências, Área de
Concentração: Economia Aplicada.

PIRACICABA

Estado de São Paulo - Brasil

Julho -2001 


\title{
FLUXOS DE PRODUÇÃO E CONSUMO DE MILHO NO SUL E SUDESTE DO BRASIL
}

\author{
VIVIANE VUOLO RISSETO
}

Engenheiro Agrônomo

\section{Orientador: Prof. Dr. PAULO FERNANDO CIDADE DE ARAÚJO}

Dissertação apresentada à Escola
Superior de Agricultura "Luiz de
Queiroz", Universidade de São
Paulo, para obtenção do título de
Mestre em Ciências, Área de
Concentração: Economia Aplicada.

PIRACICABA

Estado de São Paulo - Brasil

Julho - 2001 


\section{Dados Internacionais de Catalogação na Publicação (CIP)} DIVISÃO DE BIBLIOTECA E DOCUMENTAÇÃO - ESALQ/USP

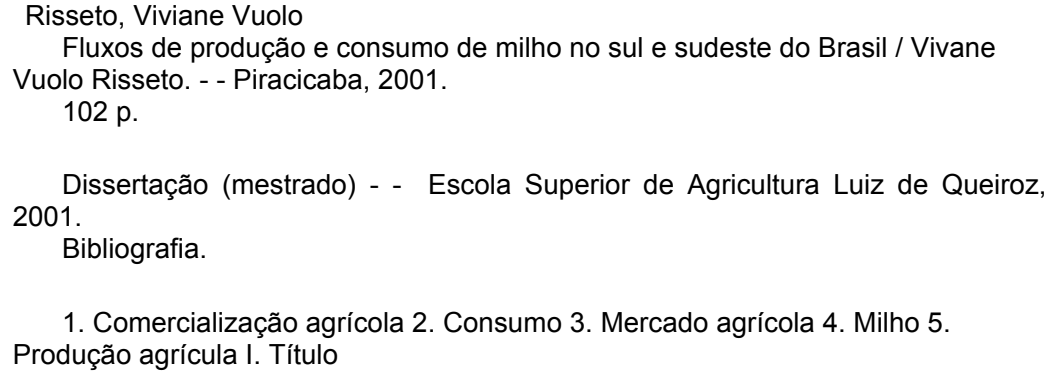

CDD 338.17315

\section{"Permitida a cópia total ou parcial deste documento, desde que citada a fonte - O autor"}




\section{DEDICO}

Aos meus pais, Pedro Henrique e Maria José, que certamente são os grandes responsáveis por essa vitória. 


\section{AGRADECIMENTOS}

Ao professor Paulo Cidade, pela orientação dedicada e paciência, por acreditar no meu trabalho e principalmente pelo amigo que se mostrou nos momentos mais difíceis.

Em especial agradeço ao grande amigo Era, pela amizade e por sempre estar ao meu lado, me incentivando e apoiando.

Ao amigo e professor Alexandre Mendonça de Barros, pelas oportunidades acadêmicas oferecidas desde a graduação, pelo imensurável apoio e, acima de tudo, pela motivação.

Ao Celso Toledo, que se tornou uma pessoa muito especial e única na minha vida.

Às amigas Trá e Arrá, pela amizade e carinho que recebi, com que pude transformar essa batalha em inesquecíveis momentos agradáveis.

Às amigas Fabi e Bia pela amizade demostrada nos momentos de dificuldade.

Aos funcionários do Departamento de Economia, Sociologia e Administração da ESALQ: Maeli, Ligiane, Elenice, Luciane e Pedro, pela atenção e simpatia com que sempre me atenderam.

À FEALQ e FAPESP pelas bolsas concedidas, que viabilizaram a realização do curso.

À Cargill Agrícola S.A. pelo apoio para realização do mestrado, em especial o Engenheiro Agrônomo Marcello Moreira, que possibilitou a compatibilização do trabalho profissional com a atividade acadêmica.

À Deus, pela vida. 


\section{SUMÁRIO}

Página

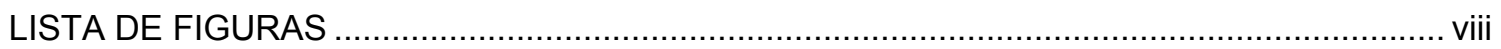

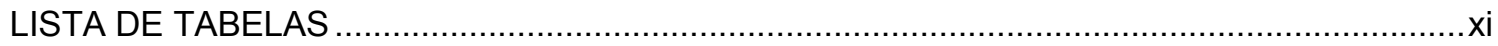

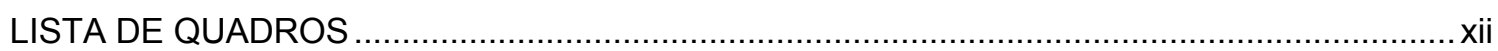

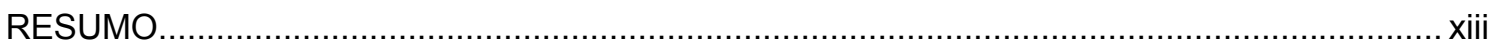

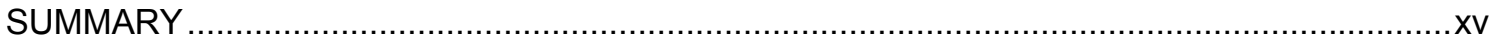

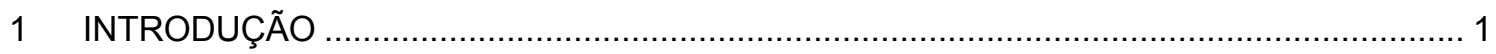

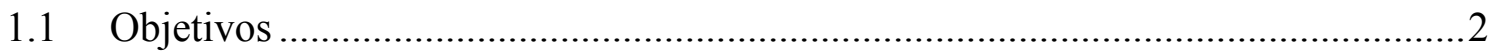

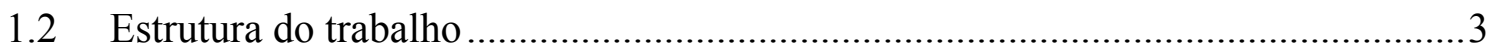

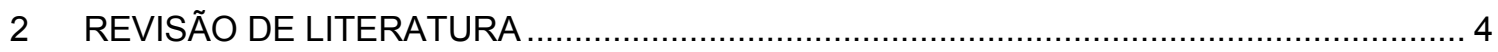

2.1 Relações de mercado e modernização da agricultura ..........................................4

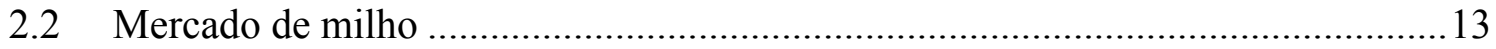

3 METODOLOGIA

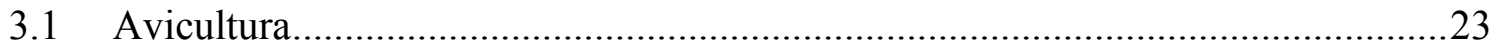

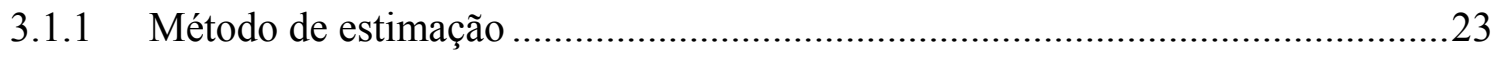

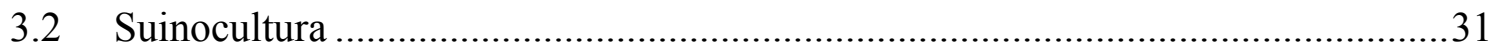

3.2.1 Método de estimação ….............................................................................

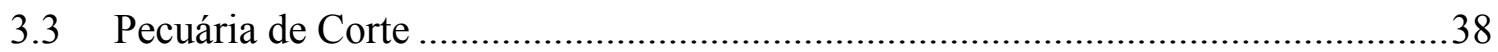

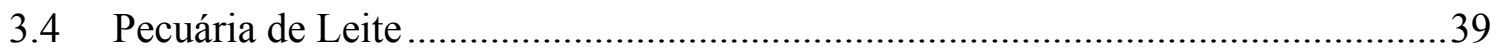




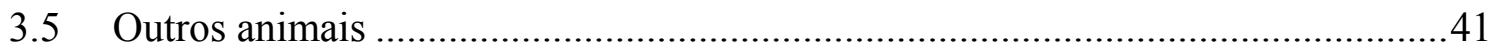

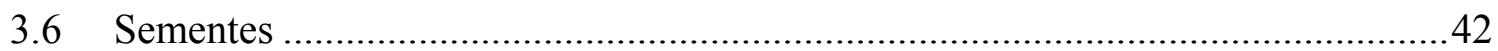

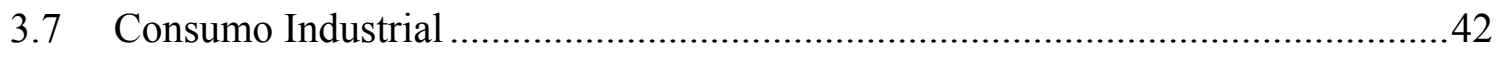

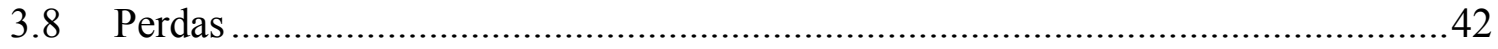

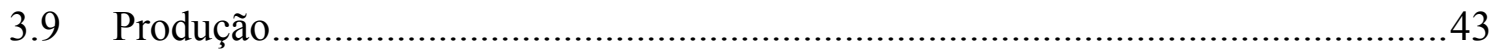

3.10 Comportamento dos Preços: Variação Estacional .............................................43

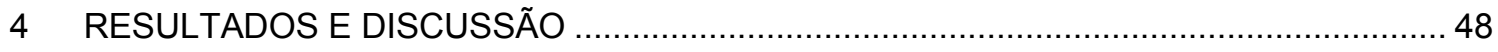

4.1 Resultados das Pesquisas de Campo .......................................................... 48

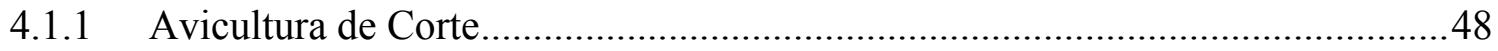

4.1.2 Avicultura de Postura .................................................................................49

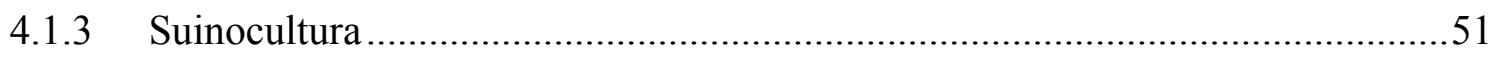

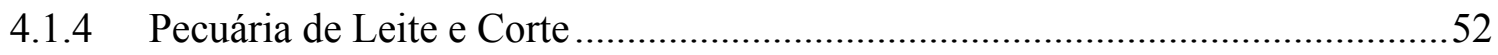

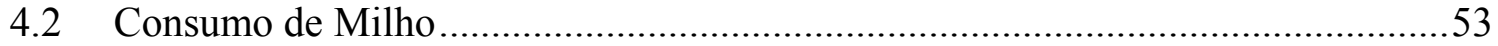

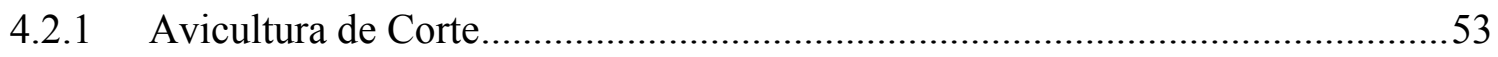

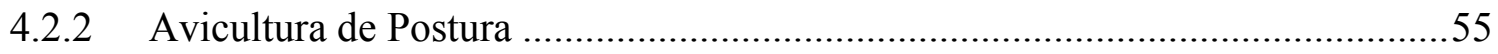

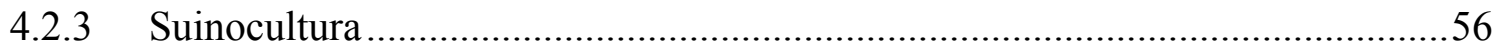

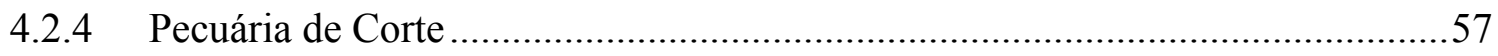

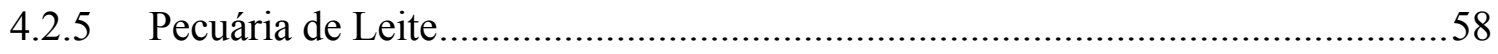

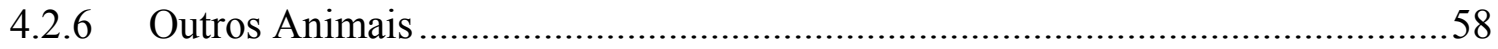

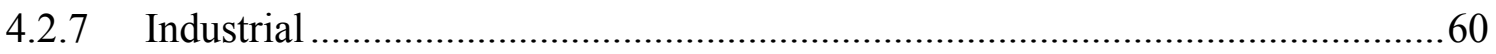

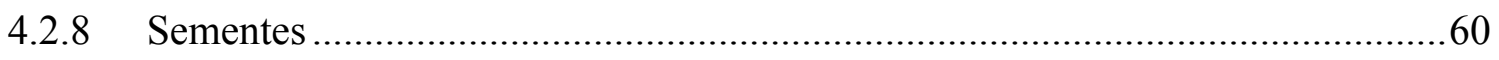

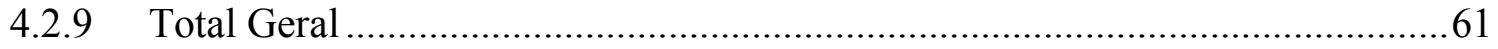

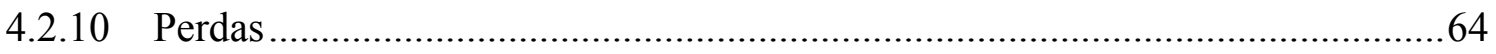

4.3 Análise dos Déficits e Excedentes ao Longo do Ano .........................................65

4.4 Variação Estacional do Preço do Milho.....................................................................69

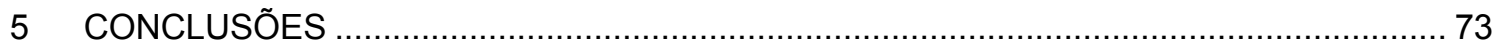

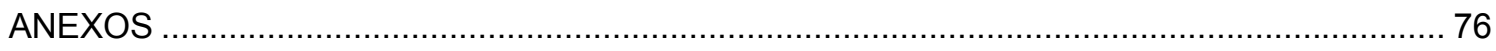

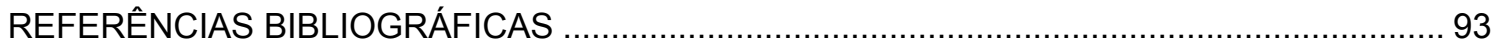


APÊNDICES 


\section{LISTA DE FIGURAS}

Página

1 Produção mundial de milho, trigo e arroz, 1990 a 1999 (em milhões de toneladas) ................ 5

2 Produção brasileira de milho e soja, 1990 a 1999 (em mil toneladas) ................................... 5

3 Colheita do milho e da soja segundo os grupos de área total (em hectares) ........................ 6

4 Participação dos EUA, China, Brasil, México, Argentina e outros países na produção mundial

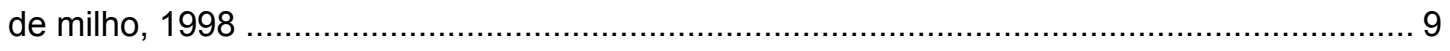

5 Produtividade em toneladas por hectare, Mundial, EUA, China, Argentina e Brasil .............. 10

6 Quantidade colhida de milho, segundo a tecnologia aplicada, Brasil ................................. 11

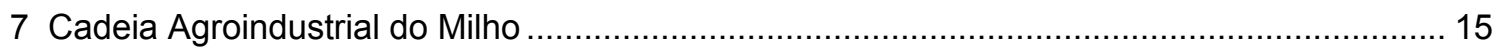

8 Principais Países Exportadores de Carne de Frango - 1998 ......................................... 18

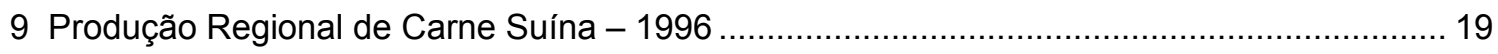

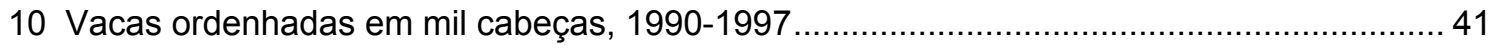

11 Consumo de milho na avicultura de corte do Rio Grande do Sul, Paraná e Santa Catarina,

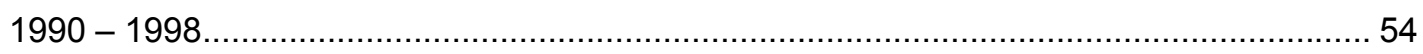

12 Consumo de milho na avicultura de corte de São Paulo, Minas Gerais, Rio de Janeiro e Espirito do Santo, 1990 - 1998

13 Consumo de milho na avicultura de postura nas regiões Sul e Sudeste do Brasil, 1990 1998 
14 Participação dos estados das regiões Sul e Sudeste do Brasil na avicultura de postura, 1998

15 Consumo de milho na suinocultura do Rio Grande do Sul, Paraná e Santa Catarina, 1990 1998 57

16 Consumo de milho na suinocultura de São Paulo, Minas Gerais, Rio de Janeiro e Espirito do Santo, 1990 - 1998 57

17 Consumo de milho na pecuária de corte nas regiões Sul e Sudeste do Brasil, 1990 - 199858

18 Consumo de milho dos outros animais nas regiões Sul e Sudeste do Brasil, 1990 - 1998 . 59

19 Participação dos estados das regiões Sul e Sudeste do Brasil em outros animais, 1998 .... 59

20 Participação do consumo de milho na indústria no Brasil, 1998 60

21 Participação dos segmentos que consomem milho nas regiões Sul e Sudeste, 1990 . 62

22 Participação dos segmentos que consomem milho nas regiões Sul e Sudeste, 1998 62

23 Consumo de milho nas regiões Sul e Sudeste, 1990-1998. 63

24 Participação no consumo de milho dos estados das regiões Sul e Sudeste, 1990 63

25 Participação no consumo de milho dos estados das regiões Sul e Sudeste, 1998 64

26 Participação das perdas em armazenagem e transporte na produção de milho nos estados das regiões Sul e Sudeste 64

27 Produção e consumo de milho: média de 1990/98, Sul e Sudeste..... 65

28 Balanço de suprimento do milho no estado do Rio Grande do Sul, 1997 67

29 Balanço de suprimento do milho no estado de Santa Catarina, 1997 67

30 Balanço de suprimento do milho no estado do Paraná, 1997 68

31 Balanço de suprimento do milho no estado de São Paulo, 1997 68 
32 Balanço de suprimento do milho no estado de Minas Gerais, 1997

33 Índices sazonais e seus limites Superior e Inferior, obtidos a partir do método de média geométrica para o estado do Rio Grande do Sul, 1990 - 1998. 70

34 Índices sazonais e seus limites Superior e Inferior, obtidos a partir do método de média geométrica para o estado do Santa Catarina, 1990 - 1998

35 Índices sazonais e seus limites Superior e Inferior, obtidos a partir do método de média geométrica para o estado do Paraná, 1990 - 1998.

36 Índices sazonais e seus limites Superior e Inferior, obtidos a partir do método de média geométrica para o estado de São Paulo, 1990 - 1998

37 Índices sazonais e seus limites Superior e Inferior, obtidos a partir do método de média geométrica para o estado de Minas Gerais, 1990 - 1998 


\section{LISTA DE TABELAS}

Página

1 Participação percentual dos grupos de produtores rurais, em salário mínimo anual................ 8

2 Produtividade do milho, segundo a tecnologia aplicada, Brasil (em Kg/ha) ....................... 10

3 Produção Regional de Milho, Brasil, 1990 -1999 (em mil toneladas) ….............................. 16

4 Importação de Milho pelo Brasil, 1992-1998 (em mil toneladas) ......................................... 17

5 Exportação de Milho pelo Brasil, 1992-1998 (em mil toneladas) …................................... 21

6 Perdas (\%) de grãos na armazenagem e transporte................................................... 43

7 Consumo de sementes em mil toneladas nos estados das regiões Sul e Sudeste do Brasil, $1990-1998$

8 Percentual do consumo menos o percentual da produção dos estados da região Sul e Sudeste do Brasil, 1990 a 1998 66 


\section{LISTA DE QUADROS}

Página

1 Resultado da pesquisa de campo, avicultura de corte, 1999/2000 .................................. 49

2 Resultado da pesquisa de campo, avicultura de postura, 1999/2000 ................................ 50

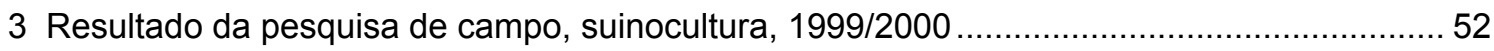




\title{
FLUXOS DE PRODUÇÃO E CONSUMO DE MILHO NO SUL E SUDESTE DO BRASIL
}

\author{
Autora: VIVIANE VUOLO RISSETO \\ Orientador: Prof. Dr. PAULO FERNANDO CIDADE DE ARAÚJO
}

\section{RESUMO}

Este estudo objetiva analisar os fluxos de produção e consumo de milho nas regiões Sul e Sudeste do Brasil, no período 1990 - 1998. Foi quantificado o consumo mensal do milho por segmento, identificando os estados que apresentam escassez ou excedente do produto. Estimaram-se os padrões de variação estacional de preço. O consumo de milho na avicultura de corte e postura, suinocultura, pecuária de corte e leite e sementes foi obtido a partir da elaboração de métodos de estimação que exigiram a aplicação de índices zootécnicos. Para testar esses índices, foram realizadas entrevistas com 71 técnicos e produtores rurais. Do lado da produção, os dados mensais foram trabalhados a partir das estatísticas do IBGE, ponderadas pela sazonalidade de colheita estimada pela CONAB. A obtenção dos índices de variação estacional de preço foi realizada a partir do procedimento proposto por Hoffmann (1969), utilizando a média geométrica móvel. Os resultados mostraram que o consumo de milho na avicultura de corte cresceu $76 \%$ no Sul e $51 \%$ no Sudeste nos anos 90 . Por outro lado, o consumo na avicultura de postura ficou praticamente estagnado nesse período. No caso da suinocultura, o consumo cresceu $72 \%$ no Sul e $63 \%$ no Sudeste. O acréscimo na pecuária de corte foi de $69 \%$ e $73 \%$, nas regiões Sul e Sudeste, respectivamente. Na região Sul, o consumo de milho aumentou $63 \%$ no período e no Sudeste, $42 \%$. Os maiores responsáveis por esses aumentos foram o Rio Grande do Sul e Minas Gerais, respectivamente. Os demais estados não apresentaram mudanças significativas. As perdas no transporte e armazenagem foram de 1,97 milhão de toneladas, $8,84 \%$ da produção. O Paraná apresentou maior excedente, seguido de Rio Grande do Sul e Minas Gerais. Por outro lado, São Paulo é o maior deficitário. Não foi possível quantificar o consumo nas propriedades rurais. Os resultados mostram que os déficits 
estimados são "proxies" das quantidades mínimas importadas de outros estados. Por outro lado, os excedentes podem ser, na realidade, menores. Como esperado, o índice sazonal do preço do milho atinge os menores valores na safra. Minas Gerais foi o estado que apresentou o menor índice sazonal, possivelmente por não haver escassez de milho ao longo do ano. 


\title{
PRODUCTION AND CONSUMPTION FLOWS OF CORN IN THE SOUTH AND SOUTHEAST OF BRAZIL
}

\author{
Author: VIVIANE VUOLO RISSETO \\ Adviser: Prof. Dr. PAULO FERNANDO CIDADE DE ARAÚJO
}

\section{SUMMARY:}

This dissertation analyses the production and consumption flows of corn in the South and Southeast regions of Brazil, during the 1990-1998 period. The monthly corn consumption was estimated in each segment, identifying the states that have deficits and surpluses of the product. The patterns of seasonal price variations were also estimated. The corn consumption in the chicken meat, eggs, pork meat, cattle meat, cattle dairy and seeds segments was obtained with estimation procedures that required the application of technical coefficients. In order to evaluate those indices, 71 specialists and producers were surveyed. The monthly production data was obtained employing the CONAB estimated harvest seasonal patterns to the yearly IBGE production data. The seasonal price variations were estimated using a method proposed by Hoffman (1969), based on geometric moving averages. The results show that the chicken meat segment corn consumption grew $76 \%$ in the South and $51 \%$ in the Southeast, during the 90 's. On the other hand, in the eggs segment the corn consumption practically didn't change during this period. For the pork meat segment, the consumption increase was $72 \%$ in the South and $63 \%$ in the Southeast. The increment for the cattle meat segment was $69 \%$ and $73 \%$, respectively, for the South and Southeast regions. In the Brazilian South region as a whole, the corn consumption increased $63 \%$ in the period. In the Southeast, the growth was $42 \%$. Respectively, the states of Rio Grande do Sul and Minas Gerais were the main drivers of this performance. The consumption for the other states didn't change very much. The transportation and storage losses were 1,97 million of tons, $8,84 \%$ of total production. The highest surpluses were registered in Paraná, followed by Rio Grande do Sul and Minas Gerais. On the other side, the state of São Paulo displayed the largest production deficit. It wasn't possible to estimate the corn consumption in the small and subsistence farms of the regions. The results suggest that the 
estimated deficits are proxies for the least amount of corn imported from other states. On the other hand, the real surpluses may be, in fact, smaller than the findings of this research. As expected, the corn price seasonal variations reach their lowest values during the harvest period. Minas Gerais was the state with smaller seasonal variation, probably due to the fact that there is no corn deficit during the year. 


\section{INTRODUÇÃO}

O abastecimento do mercado de milho no Brasil é feito por produtores tradicionais e modernos. As características agronômicas do milho e a estrutura de mercado influenciam a existência desta dualidade tecnológica que caracteriza o desenvolvimento desta lavoura.

Nos anos recentes, transformações vêm ocorrendo tanto na organização produtiva como na comercialização do milho. O crescimento no número de agricultores que adotam técnicas mais modernas de produção, novos instrumentos de comercialização, crescente influência do mercado internacional na formação do preço interno, contrato futuro negociado na BM\&F e diminuição da intervenção estatal são alguns exemplos da rápida mudança que vem ocorrendo no setor.

Entender a estrutura atual e as transformações que vêm ocorrendo necessariamente exige conhecer e compreender os mecanismos de interação do mercado consumidor com a produção. O progresso tecnológico da lavoura e os fatores que o condicionam parece ser aspecto relevante na busca desta compreensão.

Diversos estudos têm procurado explicar os fatores que condicionam as mudanças tecnológicas e o padrão de adoção das inovações técnicas. No entanto, poucos têm utilizado instrumental teórico, que faça referência ao setor agrícola como um todo, para entender o funcionamento e as mudanças na dinâmica do mercado de produtos específicos.

Em face das recentes alterações e da importância da lavoura de milho na economia agrícola brasileira, torna-se necessária análise detalhada do mercado, bem como das relações

entre mercado e desenvolvimento tecnológico da lavoura. $\mathrm{O}$ alicerce deste estudo é, portanto, o mapeamento do consumo de milho. No entanto, não há na literatura trabalhos que meçam precisamente quando, onde e por qual setor a produção de milho é consumida. 
As empresas que utilizam milho como matéria-prima, os agricultores e, devido ao possível aumento das transações envolvendo contratos futuros; corretoras, bancos e empresas que operam no mercado internacional, certamente demandam estudos que indiquem quais as possibilidades de expansão e desenvolvimento técnico da lavoura, bem como a análise do possível impacto destes eventos na dinâmica do mercado. Esta questão, por sua vez, só poderá ser abordada quando existir um mapeamento detalhado de como é consumida a produção de milho. Medir detalhadamente o consumo de milho é o objetivo central deste estudo.

\subsection{Objetivos}

O presente trabalho tem como objetivo principal analisar os fluxos de produção e consumo de milho ao longo do ano nos principais estados das regiões Sudeste e Sul do Brasil, no período 1990 - 1998. A partir desta análise, poder-se-á conhecer melhor o funcionamento do mercado de milho nas principais regiões produtoras/ consumidoras. Para isto serão analisados o papel dos agentes que participam do mercado e sua logística operacional.

Os objetivos específicos são:

- quantificar o consumo mensal do milho por segmento para os principais estados consumidores nas regiões Sul e Sudeste do Brasil;

- identificar os estados que apresentam escassez ou excedente de milho em determinadas épocas do ano;

- estabelecer os padrões de variação estacional de preço do milho no período 1990-1998 nos principais estados produtores de milho das regiões Sul e Sudeste do Brasil, determinando a média geométrica móvel centralizada, o índice estacional, o índice de irregularidade e o índice estacional puro ("índice sazonal”) dos preços. 


\subsection{Estrutura do trabalho}

O capítulo 2 apresentará a revisão bibliográfica. O capítulo 3 descreverá qualitativamente o mercado de milho no Brasil e suas relações com o resto do mundo. No capítulo 4 será apresentado a metodologia. O capítulo 5 conterá uma discussão detalhada dos resultados obtidos nas estimativas dos diversos segmentos de mercado vis-à-vis a produção doméstica. Esse capítulo será dividido em 4 itens: (i) resultados das pesquisas de campo; (ii) consumo de milho; (iii) análise dos déficits e excedentes ao longo do ano; e, (vi) variação estacional do preço do milho. No capítulo 6 serão apresentadas as principais conclusões da pesquisa. 


\section{REVISÃO DE LITERATURA}

\subsection{Relações de mercado e modernização da agricultura}

Uma questão instigante quando se estuda o mercado de produtos agrícolas, que nem sempre recebe a devida atenção, refere-se ao processo de geração e difusão de inovações tecnológicas e suas relações com o mercado. O caso do milho, em particular no Brasil, apresenta um amplo campo de estudo.

O milho compete com o trigo e arroz pelo título de grão mais produzido no mundo (figura 1). Esse fato, relativamente recente, deve-se ao aumento da demanda mundial por milho. No entanto, no Brasil, o milho, que por muito tempo foi o grão mais produzido no país, perdeu a liderança para a soja (figura 2). Os fatores que influenciaram o menor aumento na produção total de milho, quando comparados aos da produção da soja, estão intimamente relacionados com as características distintas de produção e mercado desses produtos. 


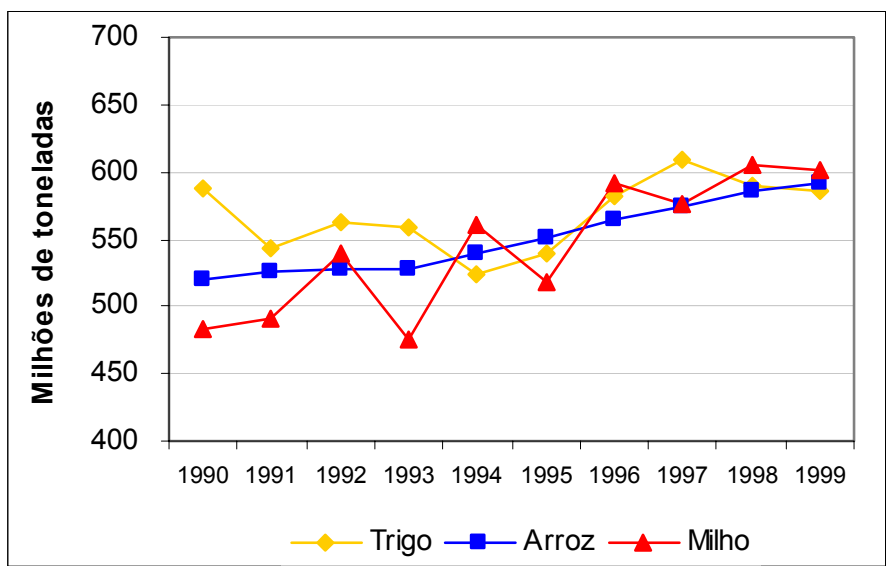

Figura 1 - Produção mundial de milho, trigo e arroz, 1990 a 1999 (em milhões de toneladas)

Fonte: USDA, 1999.

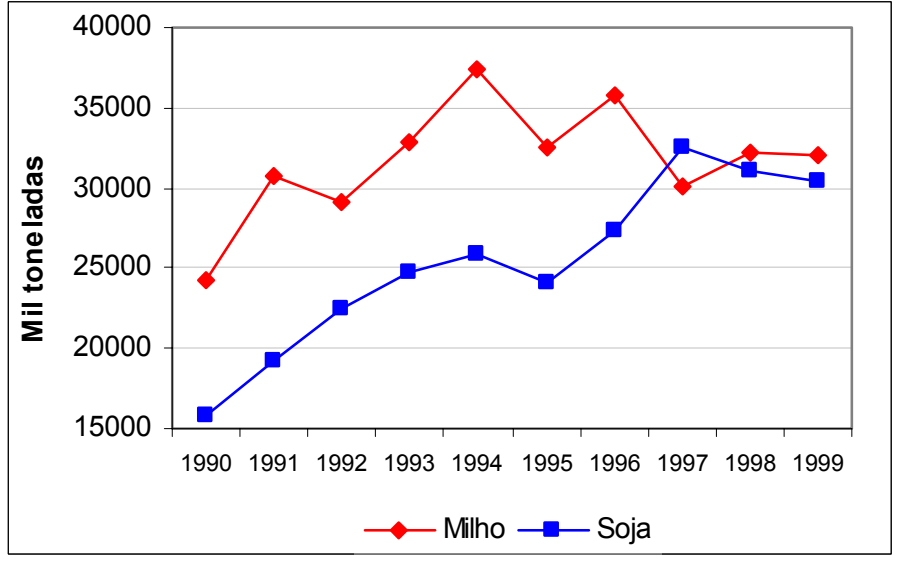

Figura 2 - Produção brasileira de milho e soja, 1990 a 1999 (em mil toneladas)

Fonte: USDA, 1999.

Ao analisar o mercado de milho brasileiro, o primeiro ponto de destaque é a questão do tamanho das propriedades. Como ilustra a figura 3, do total do milho colhido no Brasil, $44 \%$ tem origem em propriedades com menos de 100 hectares. Tomando a soja como base para comparação, apenas $25 \%$ da colheita da oleaginosa provêm de propriedades menores de 100 hectares. 

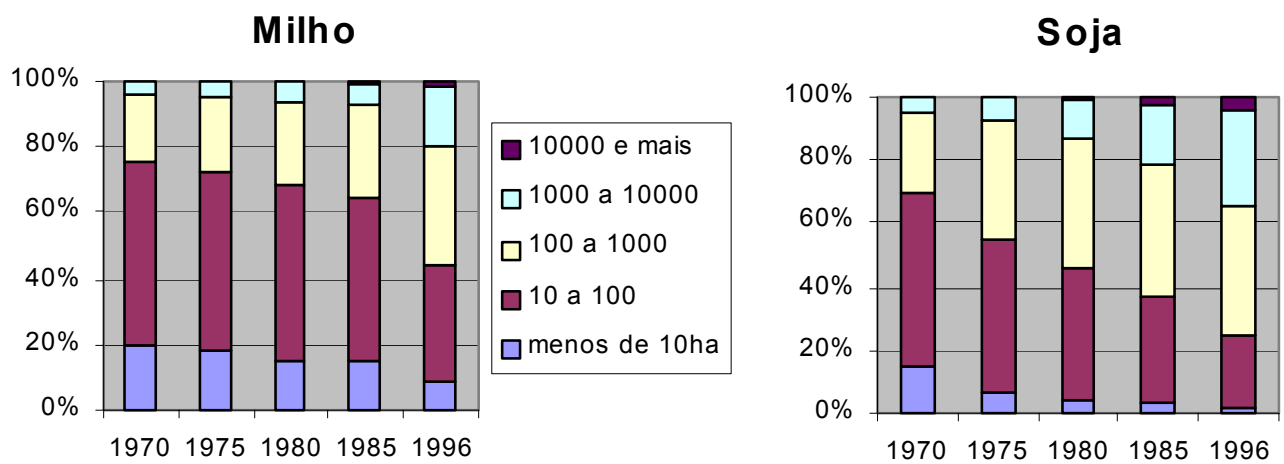

Figura 3 - Colheita do milho e da soja segundo os grupos de área total (em hectares)

Fonte: IBGE - Censos Agropecuários, 1970, 1975, 1980, 1985 e 1995/96

$\mathrm{Na}$ agricultura, sistemas de produção em larga escala não demonstram ter a mesma superioridade quando comparados à indústria. Owen (1975) argumenta que a eficiência produtiva da típica propriedade familiar dos Estados Unidos é insuperável quando comparada a qualquer indústria agrícola do resto do mundo.

No entanto, é inegável que propriedades maiores apresentam vantagens que não devem ser desprezadas. Cohen (1956) divide as vantagens das grandes propriedades em duas categorias: economias de mercado e economias técnicas. O aumento da área proporciona ao produtor maior poder de barganha podendo baratear a compra de insumos e elevar o preço do produto, ou seja, o produtor com maior área pode obter maior competitividade.

As economias técnicas são numerosas. O aumento da área permite ao agricultor utilizar máquinas caras e especializadas de maneira contínua, explorando melhor todo o potencial que o equipamento proporciona. Os custos com construções também diminuem quando a escala aumenta. Os trabalhadores das grandes propriedades podem se dedicar àquelas atividades em que possuem maiores aptidões naturais. A especialização do trabalho aumenta e, consequentemente, aumenta também a produtividade dos trabalhadores.

Cohen (1956) aponta, por outro lado, algumas vantagens das pequenas propriedades. O aumento da escala, a partir de determinado ponto, dificulta a supervisão do trabalho, reduzindo a eficiência das grandes propriedades. Owen (1975), destaca esse ponto mostrando que "o aumento do tamanho da propriedade resultará na necessidade de mandar o trabalhador "para a colina", isto é, além do controle e supervisão do operador". 
Quanto à possibilidade de especialização do trabalho, citada anteriormente, Owen (1975) destaca que o trabalho agrícola não é tão susceptível à divisão quanto o trabalho industrial. Desta forma, as vantagens da grande propriedade e os ganhos de escala não são evidentes na agricultura como na indústria.

Rezende (1985), estudando a produção de milho, mostra que esta é realizada por pequenos produtores em moldes tradicionais. Voll (1984) destaca que grande parte das propriedades que cultivam o milho o fazem em conjunto com diversos produtos que abrangem quase a totalidade da dieta familiar. Nestes casos, o milho é plantado para alimentar os animais que serão consumidos na própria propriedade.

Esta ilustração da propriedade que cultiva milho serve para enfatizar a sua importância como lavoura das unidades produtivas que praticam agricultura de subsistência. $O$ fato de 0 milho ser utilizado para subsistência e produzido para atender o mercado interno, teve forte influência no desenvolvimento desta cultura

Recentemente, a distinção entre produtos domésticos e exportáveis perdeu sentido. No entanto, durante muito tempo, diversos autores faziam tal distinção entre os produtos agrícolas, e utilizavam as diferenças dos mercados desses dois grupos de produtos para explicar o desenvolvimento de determinadas lavouras.

Barros et al. (1977) classificam os produtos agrícolas em 3 grupos: alimentos (milho, feijão, arroz, mandioca, etc.); produtos utilizados como matéria-prima para indústria (algodão e cana); e produtos exportáveis (café, cacau, mamona). Melo (1979) utiliza uma classificação ligeiramente diferente, considerando o milho e o amendoim produtos intermediários; o primeiro tendendo a ser produto doméstico e o segundo exportável. Arroz, feijão e mandioca são classificados como produtos de mercado interno e soja e café como exportáveis.

Outros autores podem utilizar classificações diferentes, no entanto a lógica permanece a mesma. O mercado externo proporciona demanda mais estável para os produtos exportáveis, o que normalmente se traduz por demanda relativamente mais elástica ao preço e à renda. $\mathrm{O}$ produtor percebe essa característica na estabilidade da taxa de rentabilidade. Por outro lado, quando a demanda interna tem forte influência sobre o preço do produto, as flutuações de renda e outros fatores podem gerar movimentos mais bruscos nos preços. A rentabilidade desses produtores é mais instável, acarretando ao mercado maior insegurança (Luque e Chahad, 1990). 
Para o produtor que cultiva milho visando apenas a subsistência de sua família as flutuações de preço tem impacto restrito. No entanto, agricultores que produzem para o mercado são fortemente afetados pelas flutuações de preço. Não é difícil entender, dentro desta argumentação, que o produtor orientado pelo mercado, geralmente é mais tecnificado e capitalizado e, por procurar produtos com mercados menos voláteis, prefere cultivar os produtos exportáveis.

Rezende (1985), estudando a distribuição do valor da produção, em salários mínimos, de diversas atividades agrícolas do país, mostra claramente que no caso da soja, produto com forte influência do mercado externo na formação de preços, os produtores são mais capitalizados que no caso do milho. Os resultados, apresentados na tabela 1, mostram que, no caso do milho, $55 \%$ da produção total estão no grupo de tamanho da produção inferior a 2 salários mínimos. Para a soja, $54 \%$ encontra-se no grupo superior a 18 salários mínimos. Somente feijão e mandioca têm resultados inferiores ao do milho.

Tabela 1. Participação percentual dos grupos de produtores rurais, em salário mínimo anual

\begin{tabular}{lccccccc}
\hline \multicolumn{1}{c}{ PRODUTO } & \multicolumn{7}{c}{ GRUPOS } \\
& $<1$ & $1-2$ & $2-9$ & $9-18$ & $18-37$ & $37-100$ & $>100$ \\
\hline Algodão arbóreo & 39,2 & 16,4 & 27,1 & 7,6 & 5,2 & 3,0 & 1,5 \\
Algodão herbáceo & 10,5 & 6,8 & 26,3 & 13,6 & 11,6 & 13,3 & 17,9 \\
Arroz & 20,6 & 10,9 & 20,2 & 7,1 & 7,4 & 11,0 & 22,8 \\
Batata inglesa & 11,8 & 5,0 & 19,3 & 9,5 & 10,3 & 15,2 & 28,8 \\
Cacau & 1,7 & 2,0 & 12,7 & 12,4 & 18,4 & 28,0 & 24,9 \\
Café & 2,1 & 2,5 & 16,7 & 14,9 & 17,0 & 19,1 & 27,7 \\
Cana-de-açucar & 3,2 & 1,7 & 5,9 & 4,0 & 5,7 & 12,9 & 66,6 \\
Feijão em grão & 61,0 & 15,6 & 16,8 & 3,1 & 1,8 & 1,1 & 0,6 \\
Fumo em folha & 13,0 & 16,4 & 63,6 & 4,9 & 1,3 & 0,7 & 0,1 \\
Laranja & 22,2 & 6,5 & 17,4 & 9,9 & 9,9 & 12,5 & 21,6 \\
Mandioca & 47,7 & 20,6 & 24,1 & 3,8 & 2,3 & 1,0 & 0,5 \\
Milho & 36,0 & 19,0 & 27,7 & 6,3 & 4,9 & 4,1 & 2,1 \\
Soja & 5,5 & 7,0 & 21,3 & 12,2 & 13,7 & 20,0 & 20,3 \\
Tomate & 4,1 & 5,4 & 26,0 & 16,6 & 15,0 & 16,5 & 16,3 \\
Trigo & 8,4 & 5,9 & 23,8 & 19,9 & 16.7 & 20,9 & 10,4 \\
\hline
\end{tabular}

Fonte: Censo Agropecuário de 1975 (Tabulações Especiais). Elaborada por Rezende, 1985.

Com menor capital para investimentos, a utilização de técnicas modernas (uso de agrotóxicos e adubação) é pequena no caso do milho, principalmente em relação à soja. Em 1975, $75 \%$ das lavouras de soja utilizavam essas técnicas, enquanto apenas $12 \%$ das lavouras de milho as utilizavam. Entre 1975 e 1996 houve um expressivo aumento na utilização 
de técnicas modernas na lavoura de milho, saltando dos $12 \%$ para $60 \%$, mas ainda assim esse valor continua inferior ao caso da soja (Censos Agropecuários, 1975 e 1995/96).

A maior utilização de técnicas modernas fez a produtividade das lavouras de milho crescer acentuadamente nos últimos 20 anos, $88 \%$. No entanto, permanece bastante insatisfatória quando comparada à produtividade obtida em outros países. Estados Unidos e China, maiores produtores de milho do mundo (figura 4), alcançam níveis de produtividade de 8,44 ton./ ha e 5,11 ton./ ha, respectivamente, enquanto a produtividade média brasileira é de apenas 2,71 ton/ha (figura 5 ).

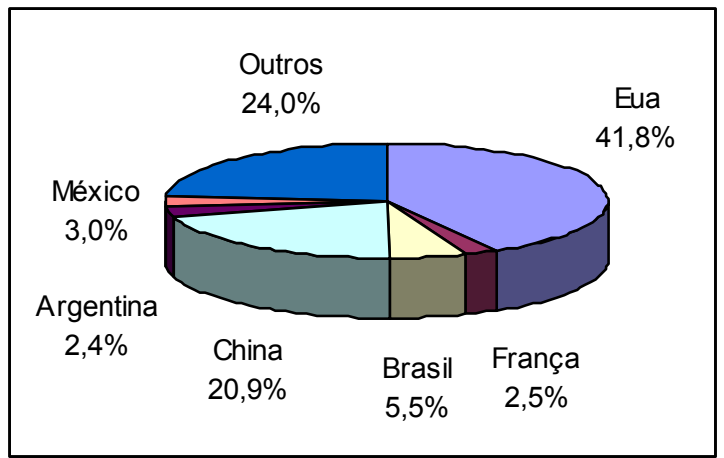

Figura 4 - Participação dos EUA, China, Brasil, México, Argentina e outros países na produção mundial de milho, 1998

Fonte: USDA, 1999 


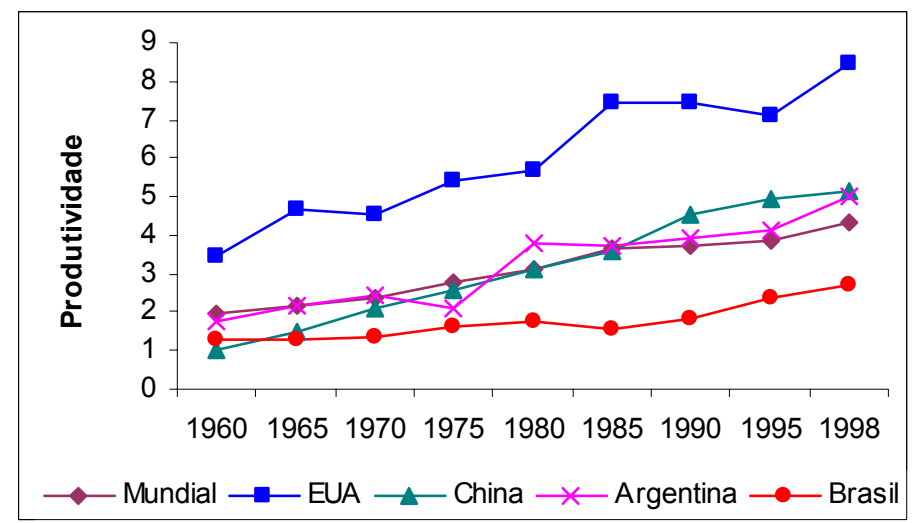

Figura 5 - Produtividade em toneladas por hectare, Mundial, EUA, China, Argentina e Brasil

Fonte: USDA, 1999

Mesmo a produtividade média de $4.257 \mathrm{Kg} / \mathrm{ha}$ alcançada pela parcela da produção advinda das lavouras que utilizam técnicas modernas (irrigação, agrotóxicos e adubação) não é menor do que a produtividade média obtida por Estados Unidos e China. Ver tabela 2. Além disso, como mostra a figura 6 , as lavouras que utilizam essa tecnologia representam apenas $5 \%$ do total da produção brasileira.

A maior produtividade média alcançada no Brasil por esse grupo de produtores, segundo o Censo Agropecuário 1995/96, foi observada no Distrito Federal (6.288 Kg/ ha) e na Bahia $(4.884 \mathrm{Kg} / \mathrm{ha})$.

Tabela 2. Produtividade do milho, segundo a tecnologia aplicada, Brasil (em Kg/ha)

\begin{tabular}{lc}
\hline Tecnologia aplicada & Produtividade \\
\hline Irrigação, agrotóxicos e adubação & 4.257 \\
Irrigação e agrotóxicos & 1.330 \\
Irrigação e adubação & 2.920 \\
Agrotóxicos e adubação & 3.406 \\
Irrigação & 1.351 \\
Agrotóxicos & 1.047 \\
Adubação & 2.333 \\
Não utiliza & 1.015 \\
Média do país & 2.406 \\
\hline
\end{tabular}

Fonte: Censo Agropecuário 1995/96 


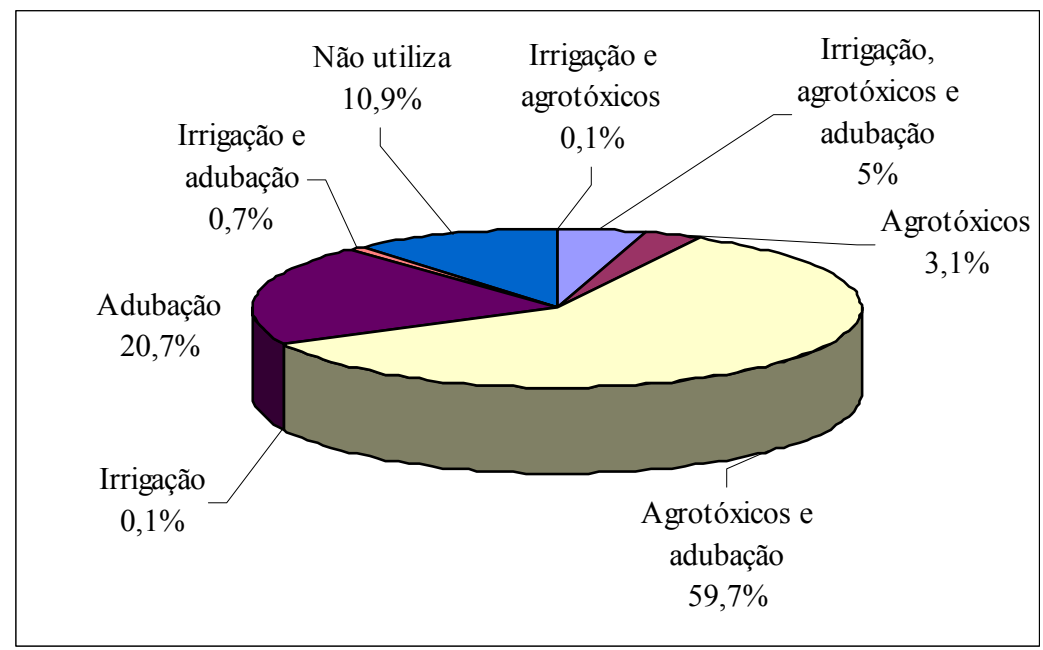

Figura 6 - Quantidade colhida de milho, segundo a tecnologia aplicada, Brasil

Fonte: Censo Agropecuário 1995/96.

A dificuldade dos agricultores investirem em inovações tecnológicas e a característica das curvas de demanda e custo do milho influenciam diretamente a geração e difusão de tecnologia para esta lavoura. No modelo de indução das inovações técnicas, Hayami \& Ruttan (1975) argumentam que a escassez relativa dos fatores influencia diretamente a direção das inovações tecnológicas. Para esses autores, países com maior escassez de terra tendem a desenvolver primeiramente técnicas que visem poupar este fator mais escasso, quais sejam, inovações biológicas e químicas. Em países com maior escassez relativa de mão-de-obra, a tendência é o desenvolvimento de inovações mecânicas, ou seja, poupadoras de mão-de-obra.

No Brasil, terra e mão-de-obra são recursos abundantes. Não havendo oferta inelástica desses fatores de produção, o incentivo a inovação foi por algum tempo reduzido. Schuh (1977) destaca que o cultivo de terras adicionais provocou variação muito pequena nos preços dos produtos. Mais recentemente, o aumento da distância dos centros consumidores foi em parte compensado pela melhoria do sistema de transporte, que barateou o custo do frete, e pelo processo de modernização da agricultura.

De Janvry (1978) enfatiza em seu modelo a importância dos grupos de pressão política na geração e difusão de novas técnicas. Grupos de pressão mais fortes tendem a influenciar a pesquisa e a extensão visando atender seus objetivos. Muitos pequenos produtores 
descapitalizados, retrato da maioria dos produtores de milho, certamente formam um grupo de menor poder político que o grupo dos grandes produtores capitalizados.

O estudo de Paiva (1975) ajuda a elucidar a questão do dualismo tecnológico como mecanismo de autocontrole. À medida que os agricultores adotam técnicas modernas, a produtividade das suas lavouras aumenta, aumentando a oferta de produto. Com o aumento da oferta o preço do produto irá diminuir. Esta redução no preço do produto será maior ou menor, de acordo com as características da curva de demanda pelo produto.

Conforme aponta Paiva (1975) e Griliches (1957), o incentivo para o agricultor adotar nova tecnologia provêm do ganho esperado com a sua utilização. Quanto maior o aumento de produtividade ou redução de custos que a nova técnica proporcionar, maior lucro o agricultor terá em adotá-la, e portanto maior seu incentivo.

Schultz (1964) destaca que o aumento relativo da produtividade não é o fator determinante do incentivo que o agricultor tem para adotar a tecnologia, e sim o aumento absoluto de produtividade. Em outras palavras, produtores que já alcançam elevada produtividade tendem a ter maior incentivo a inovação tecnológica que os produtores de baixa produtividade.

Com mais agricultores empregando a nova técnica, o preço do produto cai, reduzindo a lucratividade esperada devido ao emprego da inovação e, portanto, reduzindo o seu incentivo a adotar a nova tecnologia. Portanto, os agricultores retardatários no processo tendem a ter cada vez menos incentivo em adotar novas tecnologias.

Quando o aumento na oferta do produto pode ser colocado no mercado sem deprimir excessivamente o seu preço, a nova tecnologia será adotada por grande parcela dos produtores. Este é o caso de produtos com grande participação no mercado internacional. Por outro lado, quando o aumento da produção ocasionar grande redução no preço do produto, caso dos produtos comercializados basicamente no mercado interno, poucos agricultores terão incentivo para adotar a nova tecnologia.

O milho é um exemplo importante de produto que proporciona incentivo apenas a uma parcela dos agricultores, voltados para o mercado. E a soja é exemplo de produto em que a maior parte dos agricultores tem incentivo para adotar nova tecnologia.

Este mecanismo, denominado por Paiva de mecanismo de autocontrole, é essencial para entender a lógica do desenvolvimento das lavouras de milho. No entanto, ainda falta 
entender um ponto importante, qual seja, porque determinadas regiões se modernizam enquanto outras tendem a ficar estagnadas.

Griliches (1957) aponta um fator que parece ser essencial para compreender a relação entre mercado consumidor e desenvolvimento tecnológico das unidades de produção. A lucratividade proporcionada pela inovação tecnológica e, portanto, o incentivo do produtor a adotá-la está diretamente relacionado ao destino que o agricultor pretende dar ao produto.

Quando o milho é plantado para subsistência, "o agricultor está interessado em produzir uma certa quantidade de milho para atender suas poucas necessidades, não tendo utilidade o milho adicional que seria produzido" (Griliches, 1957). Neste caso o incentivo a mudança tecnológica praticamente não existe.

Quando o produtor utiliza o milho como insumo na produção comercial de animais, o incentivo para adotar inovações aumenta. Seguindo este raciocínio, mesmo agricultores que plantam milho para subsistência e, principalmente, agricultores comerciais, terão maior incentivo para expandir a produção utilizando novas técnicas nas regiões onde milho pode ser facilmente comercializado.

Por outro lado, a possibilidade dos produtores que cultivam para subsistência, vender excedentes do produto, aumenta a oferta e deprime o preço. Este milho, originalmente voltado para o autoconsumo, será comercializado ao preço médio vigente no mercado. Em regiões

onde a participação do autoconsumo no consumo total for alta, menor espaço deverá existir para grandes flutuações de preço.

Possivelmente, portanto, existem relações importantes entre organização produtiva e dinâmica do mercado.

\subsection{Mercado de milho}

A partir da cadeia agroindustrial do milho, esquematizada na figura 7 , pode-se saber quais são os setores e segmentos que a compõem. As categorias básicas dos insumos são: máquinas, implementos, equipamentos, fertilizantes, defensivos, sementes e terra.

A produção comercial do milho é distribuída entre armazéns gerais, traders e cooperativas, mas grande parte da produção é consumida no próprio estabelecimento. $\mathrm{O}$ 
autoconsumo nas propriedades dificulta sobremaneira os levantamentos sobre diferentes usos do grão. A estimativa apresentada no Censo Agropecuário de 1995/96 mostra que 25\% da produção total do país são consumidos nas fazendas. Existem na literatura outras estimativas nem sempre consistentes entre si.

O milho é utilizado na indústria e alimentação animal. As indústrias que o utilizam como insumo são a alimentícia e química, bebidas, fermentação, mecânica e rações ${ }^{1}$.

Sendo assim, pode-se dividir o consumo de milho em 8 segmentos de mercado: avicultura (corte e postura), suinocultura, pecuária de corte, pecuária de leite, sementes, consumo industrial e exportação.

\footnotetext{
${ }^{1}$ Para maiores detalhes ver Souza, 1996.
} 


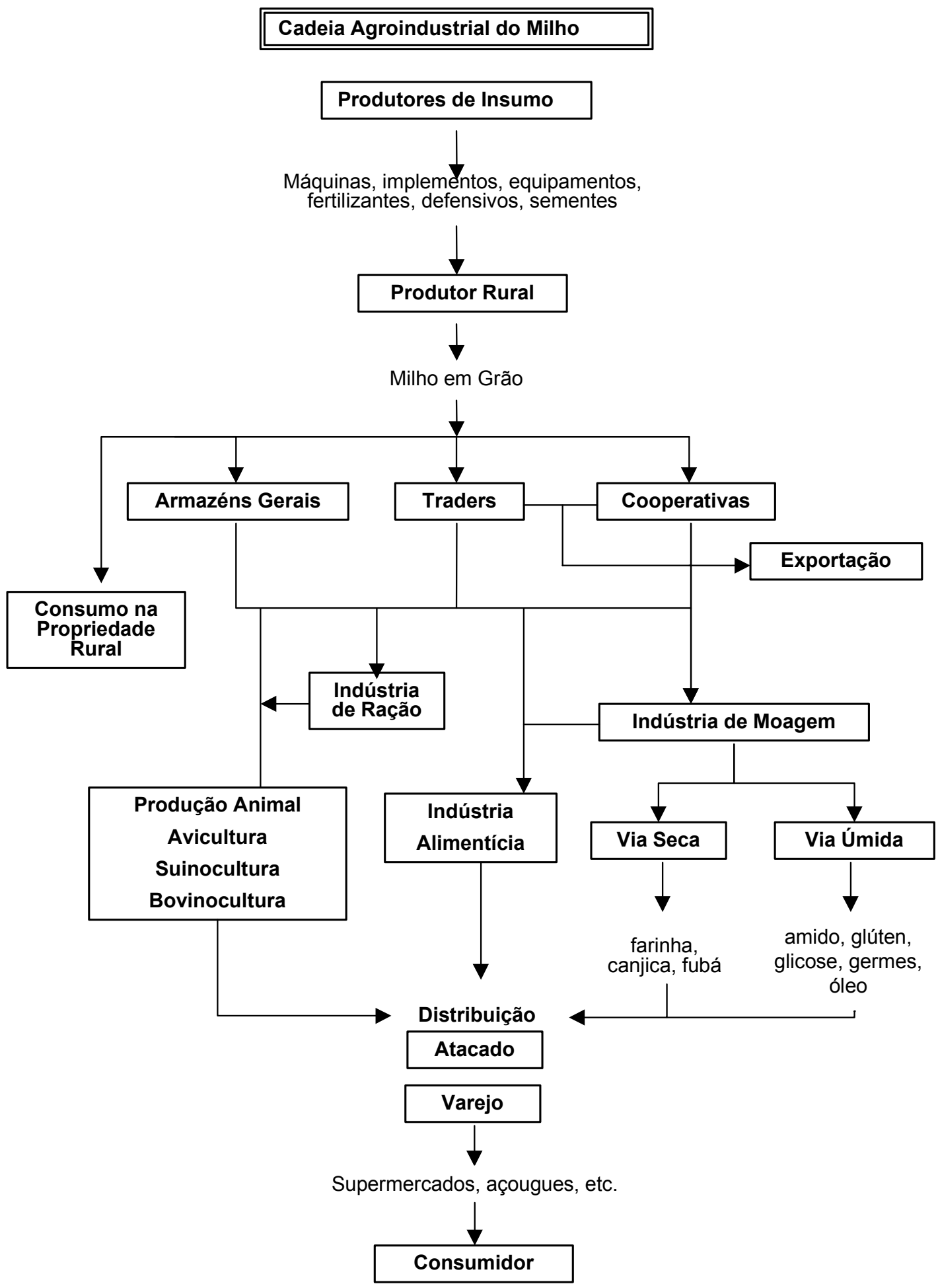

Figura 7 - Cadeia Agroindustrial do Milho

Fonte: Souza, 1996. 
Produção Doméstica - De 1990 a 1998, o aumento da produção de milho foi da ordem de $38 \%$. Nas safras $93 / 94$ e $94 / 95$ o crescimento foi de $8 \%$ e $12 \%$ respectivamente, enquanto na safra de $96 / 97$ houve queda de $18 \%$ na produção. Nos últimos cinco anos as regiões Sul e Sudeste apresentaram diminuição na produção do milho, ao contrário das demais regiões. No Centro-Oeste ocorreu incremento de 51\%; no Nordeste, de 150\%; e, no Norte, de $52 \%$.

A região Sul é a maior produtora de milho do Brasil com participação de $45 \%$ na produção total, com destaque para o Paraná ( $27 \%$ do total do país). O Sudeste tem participação de $25 \%$ e o Centro-Oeste de $21 \%$. (IBGE, 1999). A tabela 3 apresenta os dados de produção doméstica no período 1990 - 1999.

Tabela 3. Produção Regional de Milho, Brasil, 1990 -1999 (em mil toneladas)

\begin{tabular}{ccccccccccc}
\hline ANO & SP & MG & RS & PR & SC & GO & MT & MS & $\begin{array}{c}\text { Outros } \\
\text { Estados }\end{array}$ & Brasil \\
\hline 1990 & 2.766 & 2.273 & 3.957 & 5.161 & 2.674 & 1.848 & 619 & 596 & 1.453 & 21.348 \\
1991 & 4.071 & 3.712 & 2.047 & 4.827 & 1.524 & 2.886 & 670 & 933 & 2.954 & 23.624 \\
1992 & 4.075 & 3.763 & 5.534 & 7.280 & 3.261 & 2.777 & 764 & 855 & 2.198 & 30.506 \\
1993 & 3.685 & 3.801 & 4.605 & 8.175 & 3.235 & 2.598 & 908 & 921 & 2.128 & 30.056 \\
1994 & 3.199 & 3.683 & 4.751 & 8.162 & 3.331 & 3.176 & 1.164 & 1.093 & 3.928 & 32.488 \\
1995 & 4.175 & 3.745 & 5.936 & 8.988 & 3.651 & 3.477 & 1.226 & 1.435 & 3.634 & 36.267 \\
1996 & 3.544 & 3.329 & 2.965 & 7.933 & 2332 & 3.404 & 1.515 & 1.472 & 3.095 & 29.590 \\
1997 & 3.910 & 3.915 & 4.098 & 7.752 & 3.756 & 3.777 & 1.521 & 1.932 & 3.288 & 32.948 \\
1998 & 3.656 & 3.709 & 4.451 & 7.733 & 2.581 & 2.546 & 949 & 1.695 & 2.174 & 29.494 \\
1999 & 3.811 & 3.912 & 3.211 & 8.650 & 2.690 & 3.415 & 1.131 & 1.924 & 3.293 & 32.038 \\
\hline
\end{tabular}

Fonte: IBGE, 1999.

Importação - O volume de milho importado pelo Brasil atende, principalmente, à demanda de regiões específicas (Nordeste, por exemplo), que podem comprar milho no mercado externo a preços menores do que os praticados internamente, devido ao elevado custo do frete. Aproximadamente $90 \%$ das importações de milho do Brasil são provenientes da Argentina. A tabela 4 mostra as estatísticas de importação no período 1992 - 1998. 
Tabela 4. Importação de Milho pelo Brasil, 1992-1998 (em mil toneladas)

\begin{tabular}{crrrrrrr}
\hline Mês\Ano & 1992 & 1993 & 1994 & 1995 & 1996 & 1997 & 1998 \\
\hline Jan & 52,87 & 23,55 & 103,86 & 127,58 & 70,35 & 16,22 & 114,43 \\
Fev & 7,36 & 43,51 & 147,57 & 283,69 & 17,66 & 54,20 & 46,67 \\
Mar & 59,26 & 88,31 & 33,16 & 161,80 & 5,97 & 49,20 & 60,62 \\
Abr & 28,11 & 116,77 & 36,48 & 103,96 & 6,29 & 69,38 & 99,12 \\
Mai & 45,77 & 109,51 & 132,11 & 83,70 & 32,06 & 51,03 & 122,92 \\
Jun & 11,01 & 197,99 & 91,10 & 128,93 & 5,78 & 47,38 & 136,52 \\
Jul & 0,58 & 82,04 & 46,12 & 123,43 & 7,13 & 29,41 & 256,16 \\
Ago & 55,60 & 129,82 & 72,04 & 83,87 & 3,28 & 21,51 & 116,42 \\
Set & 26,35 & 132,87 & 103,88 & 94,02 & 3,24 & 56,37 & 181,61 \\
Out & 74,63 & 132,13 & 105,88 & 20,91 & 46,76 & 17,19 & 230,95 \\
Nov & 54,97 & 124,04 & 224,44 & 24,29 & 23,15 & 36,41 & 200,30 \\
Dez & 100,98 & 149,43 & 313,26 & 84,65 & 99,95 & 57,92 & 163,16 \\
TOTAL & 517,48 & $1.329,98$ & $1.409,90$ & $1.320,82$ & 321,61 & 506,23 & 1728,86 \\
\hline
\end{tabular}

Fonte: SECEX/DECEX (Ministério da Indústria, do Comércio e do Turismo), 1999

Avicultura - A avicultura mundial registrou elevados ganhos de produtividade nas últimas décadas. A enorme redução do tempo necessário para o abate do frango é um exemplo do progresso técnico deste setor. Diferentemente de outras atividades da nossa pecuária, atrasadas no uso de técnicas modernas, a avicultura conseguiu acompanhar o desenvolvimento tecnológico internacional, encontrando-se atualmente entre as mais desenvolvidas do mundo.

A segunda posição ocupada pelo Brasil no ranking dos exportadores de carne de frango mostra que o país, de fato, é competitivo no setor (figura 8). A alta produtividade alcançada na avicultura permitiu significativa redução de preços ao consumidor e o rápido crescimento do consumo interno, principalmente após o Plano Real. 


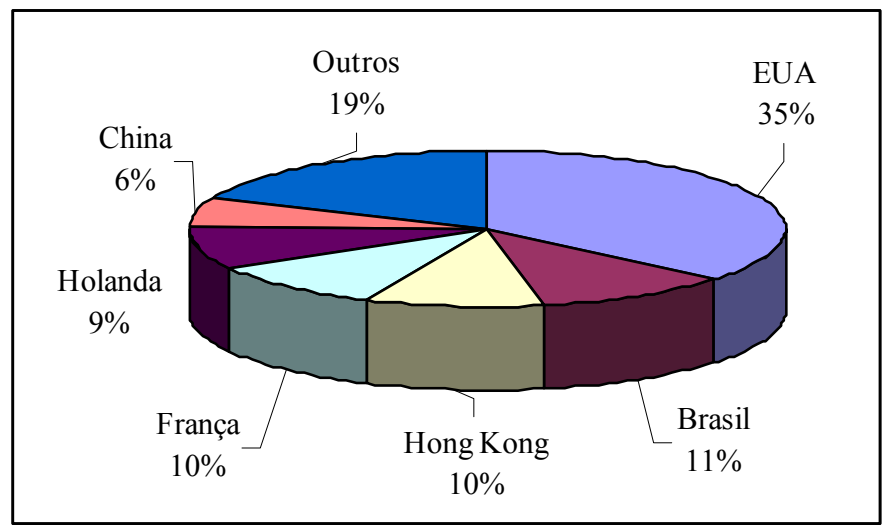

Figura 8 - Principais Países Exportadores de Carne de Frango - 1998

Fonte: USDA

Os níveis de concentração no mercado interno de aves são relativamente altos. O Estado de São Paulo e os da região Sul respondem aproximadamente por $83 \%$ da produção de aves (Associação Paulista de Avicultura - APA, 1998). O alto nível tecnológico e a concentração regional da produção determinam expressiva uniformidade nos índices de produtividade da avicultura. Ademais, essa uniformidade dos índices de produtividade e a melhor organização do setor avícola possibilitaram a obtenção de estatísticas relativamente precisas.

Suinocultura - A suinocultura tradicional é praticada por grande parte dos agricultores brasileiros. Por essa razão, a atividade apresenta índices de desempenho muito fracos, tanto no que diz respeito a indicadores zootécnicos como à taxa de mudança técnica.

Embora possuindo o terceiro maior rebanho do mundo $(4,1 \%$ do total), o Brasil responde por menos de $2,0 \%$ da produção mundial de carne suína (USDA, 1996). O rebanho nacional, que em 1996 era de 34,2 milhões de cabeças, está distribuído por todas as regiões do país. A região Sul responde por $68 \%$ da produção nacional, seguida do Sudeste (14\%). Ver figura 9. 


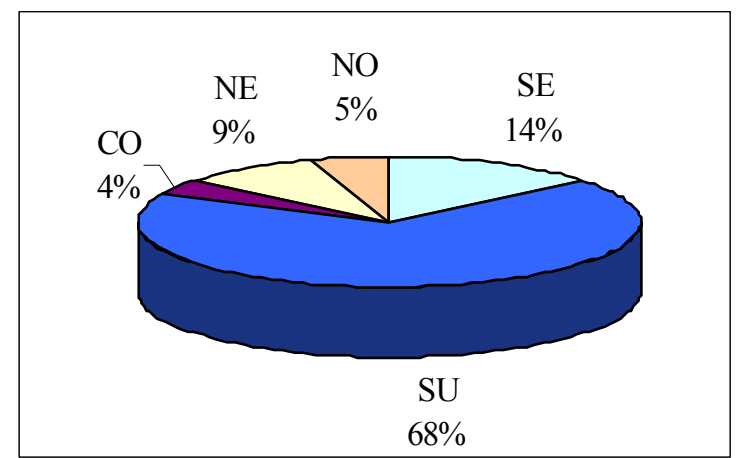

Figura 9 - Produção Regional de Carne Suína - 1996

Fonte: Associação Brasileira dos Criadores de Suínos - ABCS.

Nesse cenário, é fácil perceber a dificuldade em estimar a quantidade de milho consumido pela suinocultura. A inexistência de dados precisos sobre o número de produtores utilizando sistemas de alta tecnologia (modernos) e de baixa tecnologia (tradicionais) é a principal razão desse problema.

Apesar dessas restrições, o sistema moderno a ser considerado neste estudo é do tipo empresarial. Mantém os animais confinados em instalações especializadas que permitem controle ambiental adequado; possui animais de alto potencial genético, realiza intensa reposição de reprodutores; adota esquemas específicos de profilaxia para o controle das principais doenças e utiliza práticas nutricionais nas diferentes fases da vida do animal (EMBRAPA, 1992).

Para estimar o consumo de milho pela suinocultura, primeiramente será calculada a porcentagem de suínos criados em sistemas modernos e tradicionais nos diferentes estados das regiões Sul e Sudeste, através das respectivas estimativas de taxa de desfrute e do levantamento de dados primários.

Pecuária de corte - Neste segmento, a análise está voltada para os sistemas de criação em confinamento e semi-confinamento. Os sistemas tradicionais de criação praticamente não utilizam o milho como insumo (exceção feita, naturalmente, a situações excepcionais de mercado, quando o preço do milho não cobre os custos variáveis de produção). 
O rebanho bovino do Brasil concentra-se em regiões de fronteira ou em áreas que, por problemas de relevo, solo ou clima são de difícil uso agrícola. Assim, o rebanho está concentrado nos estados da região Centro-Oeste, no cerrado mineiro e nas áreas menos férteis dos pampas gaúchos. Na região Sudeste, os estados que mais produzem gado de corte são Minas Gerais e São Paulo, com participação de 13\% e 8\% respectivamente. (Dias et al., 1998).

Pecuária de leite - O Brasil apresenta índices medíocres de produtividade, rentabilidade e qualidade na média das propriedades rurais. Em período recente, a produtividade do rebanho leiteiro no Brasil é de apenas 1.057 litros/vaca/ano. Estados Unidos e Argentina registram níveis de produtividade iguais a 7.559 e 6.650, respectivamente. ( Jank et al, 1999).

As principais bacias leiteiras tradicionais do país estão localizadas nas regiões Sul e Sudeste do país. Segundo estatísticas de 1995/96, essas regiões concentram aproximadamente $70 \%$ da produção doméstica de leite. Entretanto, observa-se crescente migração da produção para a região dos cerrados do Centro-Oeste, com destaque para o crescimento da importância do estado de Goiás e do cerrado mineiro. A título de exemplo, Jank et al. (1999) relatam que o estado de Goiás apresentou crescimento na produção de leite de 64\% no período 1990 - 1996.

Sementes - Segundo informações da ABRASEM (1999), o volume de milho utilizado para consumo na forma de semente em relação ao consumo total do milho é muito pequeno, somando 108.795 toneladas em 1996.

A densidade de sementes híbridas, segundo essa mesma fonte, é de aproximadamente 16-18 Kg/ha. A área plantada de milho no Brasil é igual a 13.903 .726 ha em $1996^{2}$. A partir desses dados pode-se estimar que $43 \%$ a $49 \%$ do total da área plantada utilizam sementes híbridas. É provável que a pouca utilização desse tipo de tecnologia explique os baixos níveis de produtividade do milho no Brasil

Consumo Industrial - Segundo a Associação Brasileira das Indústrias de Moagem do Milho ABIMILHO, no período de 1992-1996 o consumo humano e industrial oscilou em torno de $15 \%$

\footnotetext{
${ }^{2}$ Em 1999, a área plantada foi de 12.275.354 ha.
} 
da demanda agregada do produto. Importante ainda é que, segundo essa mesma fonte, o consumo para esse fim é praticamente homogêneo ao longo do ano.

Exportações - Segmento pequeno em relação à produção de milho do país. Em 1996, por exemplo, a exportação de milho representou apenas $1 \%$ da produção total. $O$ ano recorde das exportações foi 1997. Nesse ano, 64\% das exportações brasileiras destinaram-se aos Países Baixos. Em 1998, a exportação de milho destinou-se principalmente ao Paraguai, 30\%; Estados Unidos, 28\%; Uruguai, 19\% e Bolívia, 12\%. Vale dizer ainda que em 1998 o volume exportado caiu dramaticamente, conforme indica a tabela 5.

Tabela 5. Exportação de Milho pelo Brasil, 1992-1998 (em mil toneladas)

\begin{tabular}{crrrrrrr}
\hline Mês/Ano & 1992 & 1993 & 1994 & 1995 & 1996 & 1997 & 1998 \\
\hline Jan & 0,007 & 0,018 & 0,018 & 0,137 & 0,312 & 170,409 & 0,197 \\
Fev & 0,038 & 0,164 & 0,060 & 0,054 & 0,004 & 96,870 & 1,241 \\
Mar & 0,070 & 0,034 & 0,014 & 0,038 & 0,257 & 48,453 & 0,899 \\
Abr & 0,023 & 0,000 & 2,528 & 0,000 & 4,490 & 30,822 & 0,024 \\
Mai & 0,022 & 0,000 & 0,084 & 0,015 & 52,069 & 1,868 & 0,033 \\
Jun & 0,067 & 0,481 & 0,413 & 0,093 & 0,355 & 0,873 & 0,363 \\
Jul & 0,027 & 0,548 & 0,506 & 1,224 & 116,676 & 6,461 & 1,413 \\
Ago & 0,036 & 0,865 & 0,294 & 0,612 & 102,834 & 1,008 & 0,713 \\
Set & 0,287 & 0,757 & 0,460 & 0,383 & 37,239 & 0,707 & 0,445 \\
Out & 0,186 & 0,325 & 0,089 & 3,099 & 35,773 & 0,393 & 0,770 \\
Nov & 0,084 & 0,040 & 0,015 & 4,462 & 0,074 & 0,192 & 0,437 \\
Dez & 0,017 & 0,044 & 0,162 & 0,255 & 0,083 & 0,147 & 0,637 \\
TOTAL & 0,865 & 3,275 & 4,642 & 10,372 & 350,165 & 358,204 & 7,171 \\
\hline
\end{tabular}

Fonte: SECEX/DECEX (Ministério da Indústria, do Comércio e do Turismo), 1999 


\section{METODOLOGIA}

No Brasil há reconhecida precariedade de dados estatísticos sobre o mercado de milho, o que exige o uso de alguns procedimentos metodológicos convencionais na pesquisa de problemas econômicos da agricultura, ou seja, métodos diretos e indiretos de medida (Jorgenson, 1975).

O aperfeiçoamento da metodologia e dos indicadores/ índices foi concretizado pelo levantamento de dados primários ${ }^{3}$. Para tanto, foram realizadas entrevistas com 71 técnicos e produtores. As informações de produtores e especialistas ligados aos setores em questão foram obtidas através de formulários previamente elaborados e testados.

O estudo foi dividido nos seguintes segmentos de mercado: avicultura de corte e postura, suinocultura, bovinocultura de corte e leite, sementes, consumo industrial e exportação. Do lado da produção, os dados mensais foram trabalhados a partir das estatísticas de safra do IBGE, ponderadas pela sazonalidade de colheita estimada pela CONAB.

Ademais, com a análise do comportamento dos preços internos, em período recente, espera-se captar algumas mudanças no mercado de milho.

Optou-se por pesquisar apenas as regiões Sul e Sudeste, ao invés de estudar todos os estados da federação. Segundo Risseto (1997), aproximadamente $80 \%$ do consumo de milho no Brasil ocorre nos estados das regiões Sul e Sudeste.

\footnotetext{
${ }^{3}$ Dados primários são aqueles que não foram antes coletados, e que são levantados com o propósito de atender necessidades específicas da pesquisa em andamento. As fontes básicas de dados primários são pessoas ligadas à produção de milho que tenham informações sobre o tema pesquisado e situações similares (Mattar, 1996).
} 


\subsection{Avicultura}

Para calcular o consumo de milho na avicultura foi necessário levantar junto a especialistas do setor e avicultores, alguns índices e dados como: mortalidade do nascimento ao abate; idade de abate; alojamento mensal por estado de pintos de 1 dia de corte, comerciais e matrizes; produção de ovos (estadual e mensal); e, consumo médio de ração e porcentagem de milho usada na mesma. ${ }^{4}$

A avicultura apresenta maior padronização de produção nas regiões Sul e Sudeste. Como destacado anteriormente, o estudo da avicultura não apresentou sérios problemas. Ademais, é uma atividade que se caracteriza pela concentração regional: o estado de São Paulo e os da região Sul respondem por aproximadamente $83 \%$ da produção nacional de aves.

\subsubsection{Método de estimação}

Avicultura de corte - A partir dos dados primários e secundários e dos índices técnicos foi possível estimar o consumo de milho para cada categoria da avicultura de corte.

Sete categorias de consumo foram consideradas, quais sejam: frangos; matrizes e galos em recria; matrizes e galos em produção e avós (fêmeas e machos). Em matrizes e galos em recria estão as aves que ainda não produzem pintos de 1 dia, enquanto as matrizes e galos em produção e avós incluem aves que já estão produzindo. Para cada uma dessas categorias foi levantado o consumo de ração e o percentual de milho utilizado na composição da ração.

Os índices utilizados no método de estimação foram calculados a partir da média aritmética dos dados obtidos nesta pesquisa. As médias e os respectivos desvios - padrões serão apresentados no Capítulo 5.

Os dados secundários utilizados no método de estimação como alojamento de pintos e matrizes e produção potencial de pintos foram coletados na Associação Brasileira de Pintos de Corte (APINCO).

\footnotetext{
${ }^{4}$ Os questionários da avicultura de corte e postura podem ser vistos no APÊNDICE 1.
} 


\section{Frangos}

Esta categoria é composta pelos animais criados e abatidos com a finalidade exclusiva de produzir carne.

Primeiro, estima-se o consumo mensal de ração por estado e, em seguida, o consumo de milho. Para tanto, foram utilizadas as expressões descritas a seguir.

1. Consumo mensal de ração/ estado/ mês $t=\left[\right.$ (número de pintos alojados/ estado/ mês $\mathrm{t}_{-1} \mathrm{x}$ quantidade de ração consumida/cabeça/dia $x$ dias do mês $t$ )] + [número de pintos alojados/ estado/ mês $\mathrm{t} x$ quantidade de ração consumida/cabeça/dia $\mathrm{x}$ (idade de abate do frango dias do mês $\left.\mathrm{t}_{1}\right)$;

Considerou-se nesse caso que o alojamento de pintos concentra-se próximo do $15^{\circ}$ dia, pois assim maior parcela do consumo de ração ocorre em $t+1$. Ou seja, o efeito sazonalidade é melhor captado.

2. Consumo mensal de milho/ estado/ mês $t=$ (consumo mensal de ração/ estado/ mês $\mathrm{t}$ ) $\mathrm{x}$ (\% de milho na ração) $\times$ (1- taxa de mortalidade).

\section{Matrizes em recria}

As matrizes que consomem ração no mês $t$ são aquelas que nasceram nos meses $t, t_{1}$, $t_{-2}, t_{3}, t_{-4} e t_{-5}$. Essas matrizes permanecem nessa categoria aproximadamente 168 dias, quando atingem a maturidade sexual e começam a produzir ovos comerciais. A partir dessa fase são consideradas matrizes em produção.

Nesse caso, as seguintes expressões foram utilizadas.

1. Número de matrizes alojadas/ estado/ mês $t=\left(\mathrm{n}^{\circ}\right.$ de matrizes alojadas $/$ estado/ mês $\left.\mathrm{t}\right) \mathrm{x}$ (1 - taxa de mortalidade);

2. Consumo mensal de ração/ estado/ mês $t=\left[\left(\mathrm{n}^{\circ}\right.\right.$ de matrizes alojadas nos meses $\left.\mathrm{t}_{-5}\right) \times(\mathrm{Kg}$ de ração/dia) $\times\left(n^{\circ}\right.$ de dias necessários para alcançar a maturidade sexual $-\mathrm{n}^{\circ}$ de dias dos meses $\left.\left.t_{-5}, t_{-4}, t_{-3}, t_{-2}, t_{-1}\right)\right]+\left[\left(n^{\circ}\right.\right.$ de matrizes alojadas nos meses $\left.t_{-4}, t_{-3}, t_{-2}, t_{-1}, t\right) x($ dias de consumo no mês t)]; 
3. Consumo mensal de milho/ estado/ mês $t=$ (consumo mensal de ração/ estado/ mês $\mathrm{t}$ ) $\mathrm{x}$ (\% de milho na ração).

\section{Galos em recria}

1. Número de galos alojados/ estado/ mês $t=\left(n^{\circ}\right.$ de matrizes alojadas/ estado/ mês $\left.t\right) \div\left(n^{\circ}\right.$ de fêmeas/ macho).

2. Consumo mensal de ração/ estado/ mês $t=\left[\left(\mathrm{n}^{\circ}\right.\right.$ de galos alojadas nos meses $\left.\mathrm{t}_{-5}\right) \times(\mathrm{Kg}$ de ração/dia) $x$ ( $n^{\circ}$ de dias necessários para alcançar a maturidade sexual $-n^{\circ}$ de dias dos

meses $\left.\left.t_{-5}, t_{-4}, t_{-3}, t_{-2}, t_{-1}\right)\right]+\left[\left(n^{\circ}\right.\right.$ de galos alojadas nos meses $\left.t_{-4}, t_{-3}, t_{-2}, t_{-1}, t\right) \times($ dias de consumo no mês t)];

3. Consumo mensal de milho/ estado/ mês $t=$ (consumo mensal de ração/ estado/ mês $\mathrm{t}$ ) $\mathrm{x}$ (\% de milho na ração).

\section{Matrizes em produção}

As matrizes e galos em produção já atingiram a idade de maturidade sexual e, portanto, produzem pintos. As expressões seguintes foram utilizadas para estimar o consumo de milho.

1. Número de matrizes em produção/ estado/ mês $t=$ (produção potencial de pintos de 1 dia/ estado $\left.^{5}\right) \div\left(\mathrm{n}^{\mathrm{o}}\right.$ de pintos produzidos/ matriz/ mês $)$;

2. Consumo mensal de ração/ estado/ mês $t=\left(\mathrm{Kg}\right.$ ração/ cabeça/ dia) $\times\left(\mathrm{n}^{\circ}\right.$ de matrizes em produção/ estado/ mês $\mathrm{t}) \times$ ( $\mathrm{n}^{\circ}$ dias do mês);

3. Consumo mensal de milho/ estado/ mês $t=$ (consumo mensal de ração/ estado/ mês $\mathrm{t}$ ) $\mathrm{x}$ (\% de milho na ração).

\footnotetext{
${ }^{5}$ A produção potencial de pintos capta o estado onde realmente as matrizes estão sendo criadas. Pois, os ovos e pintos podem ser exportados para outros estados.
} 


\section{Galos em produção ${ }^{6}$}

1. Número de galos em produção/ estado/mês $t=\left(\mathrm{n}^{\circ}\right.$ de matrizes em produção/ estado/ mês t) $\div\left(n^{\circ}\right.$ de fêmeas/ macho);

2. Consumo mensal de ração/ estado/ mês $t=\left(\mathrm{Kg}\right.$ de ração/ cabeça/ dia) $\times\left(\mathrm{n}^{\circ}\right.$ de galos em produção/ estado/ mês t) $\times$ ( $\mathrm{n}^{\circ}$ dias do mês);

3. Consumo mensal de milho/ estado/ mês $t=$ (consumo mensal de ração/ estado/ mês $\mathrm{t}$ ) $\mathrm{x}$ (\% de milho na ração).

\section{Avós}

As avós (fêmeas e machos) produzem matrizes. O consumo de milho foi calculado a partir das expressões descritas a seguir.

1. Número de avós em produção no Brasil/ mês $t=\left(\mathrm{n}^{\circ}\right.$ de matrizes alojadas no Brasil / mês $\left.\mathrm{t}\right)$ $\div$ (no de matriz/ avó).

2. Número de avós em produção/ estado/ mês $t=\left(\mathrm{n}^{\circ}\right.$ de avós em produção no Brasil/ mês $\left.\mathrm{t}\right)$ x (participação estadual dos avozeiros).

3. Consumo mensal de ração/ estado/ mês $t=$ (Kg de ração / cabeça/ dia) $\times\left(\mathrm{n}^{\circ}\right.$ de avós em produção/ estado/ mês $\mathrm{t}) \times\left(\mathrm{n}^{\circ}\right.$ de dias do mês $\left.\mathrm{t}\right)$;

4. Consumo mensal de milho/ estado/ mês $t=$ (consumo mensal de milho/ estado/ mês $\mathrm{t}$ ) $\mathrm{x}$ (\% de milho na ração).

\footnotetext{
${ }^{6}$ Nesse caso, apesar dos machos e fêmeas ficarem juntos, eles não comem a mesma quantidade de ração, pois os comedouros são de formatos diferentes.
} 


\section{Galos avós}

1. Número de galos avós em produção/ estado/ mês $t=\left(n^{\circ}\right.$ de avós em produção/ estado/ mês $\mathrm{t}) \div\left(\mathrm{n}^{\circ}\right.$ de fêmeas/ macho);

2. Consumo mensal de ração/ estado/ mês $t=\left(\mathrm{Kg}\right.$ de ração/ cabeça/ dia) $\times\left(\mathrm{n}^{\circ}\right.$ de galos avós em produção/ estado/ mês $\mathrm{t}) \times\left(\mathrm{n}^{\circ}\right.$ de dias do mês $\mathrm{t}$ );

3. Consumo mensal de milho/ estado/ mês $t=$ (consumo mensal de ração/ estado/ mês $\mathrm{t}) \mathrm{x}$ (\% de milho na ração).

Avicultura de postura - Neste segmento foram calculados, separadamente, o consumo de milho das aves produtoras de ovos brancos e vermelhos, pois a quantidade consumida diariamente de ração das primeiras é, geralmente, $10 \%$ inferior. Consideraram-se oito categorias, quais sejam: aves comerciais em recria, aves comerciais em produção, matrizes e galos em recria, matrizes e galos em produção e estoque de avós (fêmeas e machos).

Os dados secundários utilizados no método de estimação na avicultura de postura, como produção de ovos, alojamento de comerciais e matrizes, foram coletados na Associação Brasileira de Avicultura (APA).

\section{Poedeiras comerciais em produção}

Esta categoria é composta pelas poedeiras que produzem ovos comerciais. Primeiro, estima-se o consumo mensal de ração por estado e, em seguida, o consumo de milho. Para tanto, foram utilizadas as expressões descritas a seguir.

1. Consumo mensal de ração/ estado/ mês $t=$ (produção de ovos/ estado/ mês $\mathrm{t}) \times(\mathrm{Kg}$ de ração/ ovo);

2. Consumo mensal de milho/ estado/ mês $t=$ (consumo mensal de ração/ estado/ mês $\mathrm{t}$ ) $\mathrm{x}$ (\% de milho na ração); 


\section{Poedeiras comerciais em recria}

As poedeiras comerciais que consomem ração no mês $t$ são aquelas que nasceram nos meses $t, t_{-1}, t_{-2}, t_{-3}, t_{-4}$. Essas matrizes permanecem nessa categoria aproximadamente 134 dias, quando começam a produzir ovos comerciais. A partir dessa fase são consideradas poedeiras comerciais em produção.

Para calcular o consumo de milho foram utilizadas as seguintes expressões.

1. Consumo mensal de ração/ estado/ mês $t=\left[\left(\mathrm{n}^{\circ}\right.\right.$ de poedeiras alojadas nos meses $\left.\mathrm{t}_{-4}\right) \times($ $\mathrm{Kg}$ de ração/dia) $\times$ ( $\mathrm{n}^{\circ}$ de dias necessários para alcançar a maturidade sexual $-\mathrm{n}^{\circ}$ de dias dos meses $\left.\left.t_{-4}, t_{-3}, t_{-2}, t_{-1}\right)\right]+\left[\left(n^{\circ}\right.\right.$ de poedeiras alojadas nos meses $\left.t_{-3}, t_{-2}, t_{-1}, t\right) x($ dias de consumo no mês t)];

2. Consumo mensal de milho/ estado/ mês $t=$ (consumo mensal de ração/ estado/ mês $\mathrm{t}$ ) $\mathrm{x}$ (\% de milho na ração) $\times(1$ - taxa de mortalidade);

\section{Matrizes em recria}

As matrizes e galos em recria que consomem ração no mês t são aquelas que nasceram nos meses $t_{1} t_{-1}, t_{2}, t_{3}, t_{-4}, t_{-5}$ e $t_{6}$. Essas matrizes permanecem nessa categoria, aproximadamente 189 dias, quando começam a produzir ovos incubáveis. A partir dessa fase são consideradas matrizes em produção.

As seguintes expressões foram utilizadas para estimar o consumo de milho.

1. Consumo mensal de ração/ estado/ mês $t=\left[\left(\mathrm{n}^{\circ}\right.\right.$ de matrizes alojadas nos meses $\left.\mathrm{t}_{6}\right) \times(\mathrm{Kg}$ de ração/dia) $x$ ( $\mathrm{n}^{\circ}$ de dias necessários para alcançar a maturidade sexual $-\mathrm{n}^{\circ}$ de dias dos meses $\left.\left.t_{-6}, t_{-5}, t_{-}, t_{-3}, t_{-2}, t_{-1}\right)\right]+\left[\left(n^{\circ}\right.\right.$ de matrizes alojadas nos meses $\left.t_{-5}, t_{-4}, t_{-3}, t_{-2}, t_{-1}, t\right) x($ dias de consumo no mês t)];

2. Consumo mensal de milho/ estado/ mês $t=$ (consumo mensal de ração/ estado/ mês $\mathrm{t}$ ) $\mathrm{x}$ (\% de milho na ração) $\times$ ( 1 - taxa de mortalidade). 


\section{Galos em recria}

1. Número de galos alojados/ estado/ mês $t=\left(\mathrm{n}^{\circ}\right.$ de matrizes alojadas $/$ estado/ mês $\left.t\right) \div\left(\mathrm{n}^{\circ}\right.$ de fêmeas/ macho).

2. Consumo mensal de ração/ estado/ mês $t=\left[\left(\mathrm{n}^{\circ}\right.\right.$ de galos alojadas nos meses $\left.\mathrm{t}-6\right) \times(\mathrm{Kg}$ de ração/dia) $\times\left(n^{\circ}\right.$ de dias necessários para alcançar a maturidade sexual - $\mathrm{n}^{\circ}$ de dias dos meses $\left.\left.t_{-6}, t_{-5}, t_{-}, t_{-3}, t_{-2}, t_{-1}\right)\right]+\left[\left(n^{\circ}\right.\right.$ de galos alojadas nos meses $\left.t_{-5}, t_{-4}, t_{-3}, t_{-2}, t_{-1}, t\right) \times($ dias de consumo no mês $\mathrm{t}$ )]; (Kg de ração/ cabeça/ dia) $\times\left(n^{\circ}\right.$ de galos alojadas/ estado nos meses $t_{-5}, t_{-4}, t_{-3}, t_{-2}, t_{-1}$ e $\left.t\right) \times($ dias de consumo no mês $t$ );

3. Consumo mensal de milho/ estado/ mês $t=$ (consumo mensal de ração/ estado/ mês $\mathrm{t}$ ) $\mathrm{x}$ (\% de milho na ração).

\section{Matrizes em produção}

As matrizes e galos em produção já atingiram a idade de maturidade sexual e, portanto, produzem as poedeiras comerciais. As expressões seguintes foram utilizadas para estimar o consumo de milho.

1. Número de matrizes em produção no Brasil/ mês $t=\left(n^{\circ}\right.$ de poedeiras comerciais nascidas no mês t no Brasil $) \div\left(n^{\circ}\right.$ de poedeiras comerciais nascidas/ matriz);

2. Número de matrizes em produção/ estado/ mês $t=\left(\mathrm{n}^{\circ}\right.$ de matrizes em produção no Brasil/ mês t) $x$ (participação estadual das matrizes alojadas ${ }^{7}$ );

3. Consumo mensal de ração/ estado/ mês $t=\left(\mathrm{Kg}\right.$ de ração/ cabeça/ dia) $\times\left(\mathrm{n}^{\circ}\right.$ de matrizes em produção/ estado/ mês $\mathrm{t}) \times\left(\mathrm{n}^{\circ}\right.$ de dias do mês $\mathrm{t}$ );

4. Consumo mensal de milho/ estado/ mês $t=$ (consumo mensal de ração/ estado/ mês $\mathrm{t}$ ) $\mathrm{x}$ (\% de milho na ração).

\footnotetext{
${ }^{7}$ Acredita-se que no curto prazo a participação por estado não varia.
} 


\section{Galos em produção ${ }^{8}$}

1. Número de galos em produção/ estado/ mês $t=\left(\mathrm{n}^{\circ}\right.$ de matrizes em produção/ estado/ mês $\mathrm{t}) \div\left(\mathrm{n}^{\circ}\right.$ de fêmeas/ macho $)$;

2. Consumo mensal de ração/ estado/ mês $t=\left(\mathrm{Kg}\right.$ de ração/ cabeça/ dia) $\times\left(\mathrm{n}^{\circ}\right.$ de galos em produção/ estado/ mês t) $\times$ ( $\mathrm{n}^{\circ}$ dias do mês);

3. Consumo mensal de milho/ estado/ mês $t=$ (consumo mensal de ração/ estado/ mês $\mathrm{t}$ ) $\mathrm{x}$ (\% de milho na ração).

\section{Avós}

As avós (fêmeas e machos) produzem matrizes. O consumo de milho foi calculado a partir das expressões descritas a seguir.

1. Número de avós em produção/Brasil/ mês $t=\left(\mathrm{n}^{\circ}\right.$ de matrizes alojadas/ Brasil $/$ mês $\left.\mathrm{t}\right) \div$ (nº de matriz/ avó).

2. Número de avós em produção/ estado/ mês $t=\left(\mathrm{n}^{\circ}\right.$ de avós em produção/ Brasil/ mês $\left.\mathrm{t}\right) \mathrm{x}$ (participação estadual dos avozeiros).

3. Consumo mensal de ração/ estado/ mês $t=$ (Kg de ração / cabeça/ dia) $\times$ ( $\mathrm{n}^{\circ}$ de avós em produção/ estado/ mês $\mathrm{t}) \times\left(\mathrm{n}^{\circ}\right.$ de dias do mês $\mathrm{t}$ );

4. Consumo mensal de milho/ estado/ mês $t=$ (consumo mensal de milho/ estado/ mês $\mathrm{t}$ ) $\mathrm{x}$ (\% de milho na ração).

\section{Galos avós}

1. Número de galos avós em produção/ estado/ mês $t=\left(\mathrm{n}^{\circ}\right.$ de avós em produção/ estado/ mês $\mathrm{t}) \div\left(\mathrm{n}^{\mathrm{o}}\right.$ de fêmeas/ macho);

\footnotetext{
${ }^{8}$ Os machos e fêmeas comem no mesmo comedouro.
} 
2. Consumo mensal de ração/ estado/ mês $t=(\mathrm{Kg}$ de ração/ cabeça/ dia $) \times\left(\mathrm{n}^{\circ}\right.$ de galos avós em produção/ estado/ mês $\mathrm{t}$ ) $\times$ ( $\mathrm{n}^{\circ}$ - dias do mês $\mathrm{t}$ );

3. Consumo mensal de milho/ estado/ mês $t=$ (consumo mensal de ração/ estado/ mês $\mathrm{t}$ ) $\mathrm{x}$ (\% de milho na ração).

\subsection{Suinocultura}

Para obter o consumo de milho pela suinocultura foram levantados dados de produção estadual de carne suína. Em seguida, de acordo com o volume de carne produzido no estado e o respectivo padrão tecnológico, estimou-se a conversão alimentar média dos animais e, desta forma, o consumo de milho necessário à produção de carne de cada estado.

Foi considerado o consumo de milho de 5 diferentes categorias de animais: suínos, matrizes em recria e produção, e cachaços em recria e produção. Os índices zootécnicos necessários para determinar o consumo de milho desses animais foram obtidos em cooperativas e entrevistas com produtores das principais regiões de suinocultura das regiões Sul e Sudeste. ${ }^{9}$

O número de cabeças abatidas de suínos, peso da carcaça e rebanho foram coletados no Instituto Brasileiro de Geografia - IBGE e na Associação Brasileira dos Criadores de Suínos ABCS.

O IBGE, em 1997, modificou a metodologia para estimar o abate de suínos. Antes dessa alteração, estimava-se a partir de pesquisas que eram realizadas nos estabelecimentos do setor, porém não era captada a totalidade do abate. Após 1997, passou-se a quantificar apenas o abate sob inspeção federal, estadual e municipal (SIF). Ou seja, segundo a ABCS, apenas $67 \%$ da produção nacional de carne suína eram inspecionadas, em 1996. Assim, foram necessários utilizar dois métodos para calcular a quantidade de carne produzida nos períodos 1990 -1996 e 1997-1998.

\footnotetext{
${ }^{9}$ O questionário da suinocultura pode ser visto no APÊNDICE 2.
} 
Os dados referentes ao número de rebanho de suínos e vacas ordenhadas são disponíveis apenas até o ano de 1997. O horizonte de estudo desta dissertação precisa de dados até 1999, no primeiro caso, e até 1998, no segundo. As séries de dados disponíveis exibem tendências relativamente estáveis no longo-prazo, com exceção de alguns pontos de "quebra" devidos a fatores específicos, no caso do rebanho de suínos, e a mudanças metodológicas introduzidas pelo IBGE, no caso do leite.

As séries têm início em 1990 e são disponíveis até 1997. Portanto, são disponíveis apenas oito pontos para caracterizar a tendência das mesmas e as "quebras" estruturais de 1996 são muito pronunciadas. Essas limitações restringem o alcance das técnicas que podem ser usadas para descrever as séries e projetar os dados e, mais importante, dificultam a avaliação da adequação dos modelos.

Assim sendo, estimaram-se, por mínimos quadrados ordinários, equações do seguinte tipo:

Série $_{t}=\alpha+\beta^{*}$ Tend $_{t}+\gamma^{*}$ Dummy $_{t}+\delta^{*}$ Dummy $_{t}^{*}$ Tend $_{t}+\varepsilon_{t}$

onde Série ${ }_{t}$ refere-se à variável que se quer projetar no ano $t$; Tend $d_{t}$ é uma tendência linear em t, com início em 1990; Dummyt é uma variável binária que assume os valores 0 até 1995 e 1 a partir de 1996; $\alpha, \beta, \gamma$ e $\delta$ são parâmetros a serem estimados e; $\varepsilon_{t}$ são resíduos, por hipótese, com média zero, variância constante e não correlacionados serialmente.

Note-se que esse modelo pressupõe que a tendência de longo prazo da série é do tipo determinista. Nesse tipo de tendência, os choques têm efeitos temporários. Por hipótese, o único choque de caráter permanente teria ocorrido em 1996, por razões econômicas, no caso dos suínos, e por uma questão de mudança metodológica, no caso das vacas ordenhadas. Esse choque permanente foi caracterizado por meio da inclusão da variável binária.

Os parâmetros $\gamma$ e $\delta$ captam, respectivamente, uma mudança no intercepto e uma mudança na inclinação da tendência a partir de 1996. Tipicamente, apenas o primeiro parâmetro revelou-se significativo.

A existência de poucos graus de liberdade limita a capacidade de realizar testes para verificar a adequação da especificação do modelo. O ideal seria poder efetuar testes de raízes unitárias para checar se a série seria, de fato, estacionária em torno de uma tendência determinista. Qualquer conclusão extraída da implementação de tais testes seria, no entanto, 
temerária nesse caso. Optou-se por verificar visualmente a estrutura de resíduos do modelo para detectar a existência ou não de alguma impropriedade. ${ }^{10,11}$

Ajustado o modelo e feitas as projeções regionais, adotou-se como hipótese para distribuir o total pelos estados, a suposição de que a participação relativa dos mesmos teria se mantido, para os anos projetados, igual à que se verificou em $1997^{12}$

\subsubsection{Método de estimação}

Primeiro, estimou-se o consumo mensal de ração por estado e, em seguida, o consumo de milho. Foram calculados, separadamente, o consumo do sistema tradicional e o consumo do sistema tecnificado. Para tanto, foram utilizadas as expressões descritas a seguir.

\section{Suínos}

Período: 1990 a 1996

1. Número total de suínos abatidos/ estado/ mês $t=\left(\mathrm{n}^{\circ}\right.$ de cabeças de suínos abatidas estimado pelo IBGE) $\div$ (\% que o IBGE capta em relação ao abate estimado pelo ABCS);

Período: 1997 e 1998

2. Número total de suínos abatidos/ estado/ mês $t=\mathrm{n}^{\mathrm{0}}$ de cabeças abatidas que são inspecionadas pelo sistema federal, estadual ou municipal $) \div\left(\right.$ participação do $\mathrm{n}^{\circ}$ de cabeças abatidas sob inspeção no abate total);

\footnotetext{
${ }^{10}$ A execução de testes de raízes unitárias, mesmo tendo em vista a limitação imposta pelo tamanho reduzido da amostra, caminha na direção de confirmar a adequação da especificação acima quando se leva em consideração a quebra estrutural de 1996. Por exemplo, no caso do rebanho de suínos na região sul, a estatística de Dickey-Fuller permite rejeitar a hipótese de existência de uma raíz unitária nos resíduos do modelo acima para um nível de significância de $5 \%$ (utilizando os valores críticos de McKinnon).

${ }^{11}$ É importante frisar que as projeções são relativamente robustas à especificação exata do modelo.

${ }^{12}$ Estimou-se um modelo com tendência estocástica para a série de vacas ordenhadas da região Sudeste.
} 
3. Desfrute estadual/ ano $t=\frac{\mathrm{A} \pm \Delta \mathrm{RT}}{\mathrm{RT}} \times 100$

Onde:

$A$ = número de suínos abatidos no ano

$\mathrm{RT}$ = rebanho total

$\Delta R T=\left(R T-R T_{-1}\right)=$ variação do rebanho total

$\mathrm{RT}_{-1}=$ rebanho total no ano anterior

4. Percentual do sistema tecnificado e tradicional. Para este cálculo foi utilizada a equação abaixo, sendo Dm (taxa de desfrute do sistema tecnificado) igual a 160\% e Dt (taxa de desfrute do tradicional), 30\%. Ver EMBRAPA, 1992;

$\alpha \mathrm{Dm}+\beta \mathrm{Dt}=$ desfrute do estado

$\alpha+\beta=1$

Segundo Sesti \& Sobestiansky (1998) a participação do sistema de alta tecnologia no Brasil nos anos de 1990 e 1995 foi de $15 \%$ e $21 \%$ respectivamente. Os resultados obtidos no presente trabalho foram $15 \%$ e $20 \%$ para os mesmos anos. Assim, fica evidenciada a eficácia da metodologia utilizada.

5. Peso vivo de abate do suíno/ sistema/ estado/ mês $t=\left(\right.$ peso da carcaça $\left.{ }^{13}\right) \times$ participação do sistema tradicional ou tecnificado $) \div($ rendimento da carcaça do sistema);

\section{Consumo mensal de ração/ estado/ mês $t$}

As porcentagens utilizadas nas equações descritas a seguir dizem respeito à proporção de consumo de ração na respectiva fase de desenvolvimento. No primeiro mês de vida os leitões ainda são amamentados, portanto, não há consumo de ração. No sistema tecnificado, nos 5 meses de vida, as proporções do primeiro ao quinto mês são: $0 \%, 13 \%, 20 \%, 27 \%$ e $40 \%$, respectivamente. Para o sistema tradicional, nos 12 meses de vida, as proporções mensais são: $0 \% ; 1,5 \% ; 3 \% ; 5,2 \% ; 5,3 \% ; 6,7 \% ; 9 \% ; 10,5 \% ; 10,7 \% ; 13,4 \% ; 17,2 \%$ e $17,5 \%$, respectivamente.

\footnotetext{
${ }^{13}$ SIF e não SIF
} 
a. Consumo de ração do sistema tecnificado/ estado/ mês $t=[$ (peso vivo de abate de $\mathrm{t} x$ $40 \%)+\left(\right.$ peso vivo de abate de $\left.t_{1} \times 27 \%\right)+\left(\right.$ peso vivo de abate de $\left.t_{2} \times 20 \%\right)+($ peso vivo de abate de $\left.t_{3} \times 13 \%\right)+\left(\right.$ peso vivo de abate de $\left.\left.t_{4} \times 0 \%\right)\right] \times$ Conversão Alimentar;

b. Consumo de ração do sistema tradicional/ estado/ mês $t=[$ (peso vivo de abate de $\mathrm{t} x$ $17,5 \%)+\left(\right.$ peso vivo de abate de $\left.t_{1} \times 17,2 \%\right)+\left(\right.$ peso vivo de abate de $\left.t_{2} \times 13,4 \%\right)+($ peso vivo de abate de $\left.t_{3} \times 10,7 \%\right)+\left(\right.$ peso vivo de abate de $\left.t_{4} \times 10,5 \%\right)+$ (peso vivo de abate de $\left.t_{5} \times 9 \%\right)+\left(\right.$ peso vivo de abate de $\left.t_{6} \times 6,7 \%\right)+\left(\right.$ peso vivo de abate de $t_{7} \times$ $5,3 \%)+\left(\right.$ peso vivo de abate de $\left.t_{8} \times 5,2 \%\right)+\left(\right.$ peso vivo de abate de $\left.t_{9} \times 3,0 \%\right)+($ peso vivo de abate de $\left.t_{10} \times 1,5 \%\right)+\left(\right.$ peso vivo de abate de $\left.\left.t_{11} \times 0 \%\right)\right] \times$ Conversão Alimentar;

7. Consumo de milho/ estado/ mês $t=$ (consumo mensal de ração/ sistema/ estado/ mês $x \%$ de milho na ração/ sistema $)$ - $\mathrm{n}^{\circ}$ de cachaços e matrizes descartados $)^{14}$.

\section{Matrizes em recria}

Como uma matriz demora de 7-8 meses para ovular a primeira vez e 3 meses, 3 semanas e 3 dias para parir, considerou-se que ela permanecerá nessa categoria por 1 ano no sistema tradicional e 11 meses no tecnificado.

\section{Consumo de ração/ sistema/ estado/ mês $t$}

a. Consumo de ração do sistema tecnificado/ estado/ mês $t=\left[\left(\mathrm{n}^{\circ}\right.\right.$ de cabeças repostas em $\mathrm{t}_{10}$ $x \mathrm{Kg}$ de ração no $2^{\circ}$ mês de vida/ cabeça $)+\left(n^{\circ}\right.$ de cabeças repostas em $\mathrm{t}_{9} \times \mathrm{Kg}$ de ração no $3^{\circ}$ mês de vida/ cabeça $)+\left(n^{\circ}\right.$ de cabeças repostas em $t_{8} \times \mathrm{Kg}$ de ração no $4^{\circ}$ mês de vida/ cabeça $)+\left(n^{\circ}\right.$ de cabeças repostas em $t_{7} \times \mathrm{Kg}$ de ração no $5^{\circ}$ mês de vida/ cabeça $)+\left(n^{\circ}\right.$ de cabeças repostas em $\mathrm{t}_{6} \times \mathrm{Kg}$ de ração no $6^{\circ}$ mês de vida/ cabeça $)+\left(\mathrm{n}^{\circ}\right.$ de cabeças repostas em $t_{5} \times \mathrm{Kg}$ de ração no $7^{\circ}$ mês de vida/ abeça $)+\left(n^{\circ}\right.$ de cabeças repostas $e m t_{4} \times$ $\mathrm{Kg}$ de ração no $8^{\circ}$ mês de vida/ cabeça $)+\left(\mathrm{n}^{\circ}\right.$ de cabeças repostas em $\mathrm{t}_{3} \times \mathrm{Kg}$ de ração no $9^{\circ}$ mês de vida/ cabeça $)+\left(n^{\circ}\right.$ de cabeças repostas em $t_{2} \times \mathrm{Kg}$ de ração no $10^{\circ}$ mês de $\mathrm{vida} /$ cabeça $)+\left(\mathrm{n}^{\circ}\right.$ de cabeças repostas em $\mathrm{t}_{1} \times \mathrm{Kg}$ de ração no $11^{\circ}$ mês de vida/ cabeça $\left.)\right]$

\footnotetext{
${ }^{14}$ É necessário subtrair o descarte do abate para não contabilizar as matrizes e cachaços duas vezes. O descarte das matrizes, tanto no sistema tradicional como no tecnificado, é de $20 \%$ ao ano, pois as matrizes devem ser totalmente renovadas em 5 anos. Os cachaços do sistema tecnificado são utilizados 3 anos (descarte de1/3 ao ano). No tradicional, 6 ou 7 anos (descarte de 1/6 ao ano).
} 
b. Consumo de ração do sistema tradicional/ estado/ mês $t=\left[\left(\mathrm{n}^{\circ}\right.\right.$ de cabeças repostas em $\mathrm{t}_{11} \mathrm{x}$ $\mathrm{Kg}$ de ração no $2^{\circ}$ mês de vida/ cabeça $)+\left(\mathrm{n}^{\circ}\right.$ de cabeças repostas em $\mathrm{t}_{10} \times \mathrm{Kg}$ de ração no $3^{\circ}$ mês de vida/ cabeça $)+\left(n^{\circ}\right.$ de cabeças repostas em $\mathrm{t}_{9} \times \mathrm{Kg}$ de ração no $4^{\circ}$ mês de vida/ cabeça $)+\left(n^{\circ}\right.$ de cabeças repostas em $t_{8} \times K g$ de ração no $5^{\circ}$ mês de vida/ cabeça $)+\left(n^{\circ}\right.$ de cabeças repostas em $\mathrm{t}_{7} \times \mathrm{Kg}$ de ração no $6^{\circ}$ mês de vida/ cabeça $)+\left(n^{\circ}\right.$ de cabeças repostas em $\mathrm{t}_{6} \times \mathrm{Kg}$ de ração no $7^{\circ}$ mês de vida/ cabeça $)+\left(n^{\circ}\right.$ de cabeças repostas em $\mathrm{t}_{5}$ $x \mathrm{Kg}$ de ração no $8^{\circ}$ mês de vida/ cabeça $)+\left(n^{\circ}\right.$ de cabeças repostas em $\mathrm{t}_{4} \times \mathrm{Kg}$ de ração no $9^{\circ}$ mês de vida/ cabeça $)+\left(n^{\circ}\right.$ de cabeças repostas em $t_{3} \times \mathrm{Kg}$ de ração no $10^{\circ}$ mês de vida/ cabeça $)+\left(n^{\circ}\right.$ de cabeças repostas em $t_{2} \times \mathrm{Kg}$ de ração no $11^{\circ}$ mês de vida/ cabeça) $+\left(n^{\circ}\right.$ de cabeças repostas em $t_{1} \times \mathrm{Kg}$ de ração no $12^{\circ}$ mês de vida/ cabeça)];

2. Consumo de milho/ sistema/ estado/ mês $t=$ (consumo de ração/ sistema/ estado/ mês) $\mathrm{x}$ (\% de milho na ração/ sistema).

\section{Cachaços em recria}

Wentz et al. (1998) ressaltam que os suínos "aos 150 dias de idade, normalmente a idade de comercialização, apresentam peso superior a $100 \mathrm{Kg}$. Dessa forma não é raro observar machos com aproximadamente $150 \mathrm{Kg}$ entre seis e sete meses de idade, o que leva o produtor a usá-lo em função do seu tamanho. Cameron (1985), sugere que a produção espermática plena não ocorre antes dos oito meses de idade, apesar de os machos jovens serem utilizados para monta natural ou coleta de sêmen para inseminação artificial em torno de 200 dias."

Assim, considerou-se que o reprodutor do sistema tecnificado permanece nessa categoria até o oitavo mês de vida. No caso do sistema tradicional, levando em consideração a conversão alimentar, acredita-se que o macho atinja o peso de $150 \mathrm{Kg}$ com 12 meses de idade. 
1. Consumo de ração/ sistema/ estado/ mês $t$

a. Consumo de ração do sistema tecnificado/ estado/ mês $t=\left[\left(n^{\circ}\right.\right.$ de cabeças repostas em $t_{7} \times$ $\mathrm{Kg}$ de ração no $2^{\circ}$ mês de vida/ cabeça $)+\left(n^{\circ}\right.$ de cabeças repostas em $\mathrm{t}_{6} \times \mathrm{Kg}$ de ração no $3^{\circ}$ mês de vida/ cabeça $)+\left(n^{\circ}\right.$ de cabeças repostas em $t_{5} \times \mathrm{Kg}$ de ração no $4^{\circ}$ mês de vida/ cabeça $)+\left(n^{\circ}\right.$ de cabeças repostas em $t_{4} \times \mathrm{Kg}$ de ração no $5^{\circ}$ mês de vida/ cabeça $)+\left(n^{\circ}\right.$ de cabeças repostas em $\mathrm{t}_{3} \times \mathrm{Kg}$ de ração no $6^{\circ}$ mês de vida/ cabeça $)+\left(\mathrm{n}^{\circ}\right.$ de cabeças repostas em $t_{2} \times \mathrm{Kg}$ de ração no $7^{\circ}$ mês de vida/ cabeça $)+\left(n^{\circ}\right.$ de cabeças repostas em $t_{1} x$ $\mathrm{Kg}$ de ração no $8^{\circ}$ mês de vida/ cabeça)]

b. Consumo de ração do sistema tradicional/ estado/ mês $t=\left[\left(\mathrm{n}^{\circ}\right.\right.$ de cabeças repostas em $\mathrm{t}_{11} \mathrm{x}$ $\mathrm{Kg}$ de ração no $2^{\circ}$ mês de vida/ cabeça $)+\left(n^{\circ}\right.$ de cabeças repostas em $t_{10} \times \mathrm{Kg}$ de ração no $3^{\circ}$ mês de vida/ cabeça $)+\left(n^{\circ}\right.$ de cabeças repostas em $t_{9} \times \mathrm{Kg}$ de ração no $4^{\circ}$ mês de vida) $+\left(n^{\circ}\right.$ de cabeças repostas em $t_{8} \times K g$ de ração no $5^{\circ}$ mês de vida/ cabeça $)+\left(n^{\circ}\right.$ de cabeças repostas em $\mathrm{t}_{7} \times \mathrm{Kg}$ de ração no $6^{\circ}$ mês de vida/ cabeça $)+\left(n^{\circ}\right.$ de cabeças repostas em $t_{6} \times \mathrm{Kg}$ de ração no $7^{\circ}$ mês de vida/ cabeça $)+\left(n^{\circ}\right.$ de cabeças repostas em $\mathrm{t}_{5} \mathrm{x}$ $\mathrm{Kg}$ de ração no $8^{\circ}$ mês de vida/ cabeça $)+\left(\mathrm{n}^{\circ}\right.$ de cabeças repostas em $\mathrm{t}_{4} \times \mathrm{Kg}$ de ração no $9^{\circ}$ mês de vida/ cabeça $)+\left(n^{\circ}\right.$ de cabeças repostas em $t_{3} \times \mathrm{Kg}$ de ração no $10^{\circ}$ mês de vida/ cabeça $)+\left(n^{\circ}\right.$ de cabeças repostas em $t_{2} \times \mathrm{Kg}$ de ração no $11^{\circ}$ mês de vida/ cabeça) $+\left(n^{\circ}\right.$ de cabeças repostas em $t_{1} \times K g$ de ração no $12^{\circ}$ mês de vida/ cabeça $)$;

2. Consumo de milho/ sistema/ estado/ mês $t=$ (consumo de ração/ sistema/ estado/ mês) $\mathrm{x}$ (\% de milho na ração/ sistema).

\section{Matrizes em produção}

1. Cabeças de animais nascidos/ estado/mês $t$

a. Sistema tecnificado: quantidade de cabeças abatidas no mês $t_{0}$ nascidas em $t_{-4}$

b. Sistema tradicional: quantidade de cabeças abatidas no mês $t_{0}$ nascidas em $t_{-11}$;

2. Número de matrizes em produção/ estado/ ano $=\left(\mathrm{n}^{\circ}\right.$ de cabeças de leitões nascidos/ sistema $) \div\left(n^{\circ}\right.$ de cabeças de leitões terminados/ porca /ano/ sistema);

3. Consumo de ração/ sistema/ estado/ mês $t=$ (Kg de ração/ dia/ cabeça/ sistema) $\times\left(\mathrm{n}^{\circ}\right.$ de dias do mês $) \times\left(n^{\circ}\right.$ de matrizes em produção/ estado/ ano); 
4. Consumo de milho/ sistema/ estado/ mês $t=$ (consumo de ração/ sistema/ estado/ mês $\mathrm{t}$ ) $\mathrm{x}$ ( $\%$ de milho na ração/ sistema).

\section{Cachaços em produção}

1. Número de cachaços em produção/ estado/ $a n o=\left(n^{\circ}\right.$ de matrizes em produção/ estado/ ano $) \div\left(n^{\circ}\right.$ de matrizes/cachaço);

2. Consumo de ração/ sistema/ estado/ mês $t=(\mathrm{Kg}$ de ração/ dia/ cabeça/ sistema) $\times$ (nº de dias do mês $\mathrm{t}$ ) $\mathrm{x}$ ( $\mathrm{n}^{\circ}$ - de cachaços em produção/ estado/ ano);

3. Consumo de milho/ sistema/ estado/ mês $t=$ (consumo de ração/ sistema/ estado/ mês $\mathrm{t}$ ) $\mathrm{x}$ (\% de milho na ração/ sistema).

\subsection{Pecuária de Corte}

Para o cálculo do uso de milho na ração dos animais confinados, pressupõe-se que, em média, um animal padrão de confinamento pesa $400 \mathrm{Kg}$ de peso vivo e consome cerca de $2 \%$ do seu peso vivo em matéria seca por dia. Desta forma, será adotado o consumo de $8 \mathrm{Kg}$ de matéria seca de ração/dia/cabeça.

Para atender as exigências nutricionais de um animal médio em confinamento a ração deve atender os seguintes níveis nutricionais: 10\% de proteína bruta, sendo $60 \%$ da matéria seca na forma de concentrado e $40 \%$ provenientes de volumoso. (NRC, 1996).

Admitindo também como percentuais de proteína na soja e no milho $46 \%$ e $9 \%$, respectivamente, tem-se:

$0,46 S+0,09 M=0,8 \mathrm{Kg}$ de PB

$S+M=4,8 \mathrm{Kg}$ de $M S$

Onde $\quad M=$ Milho 


$$
\begin{aligned}
& S=\text { Soja } \\
& M S=\text { Matéria Seca }{ }^{15}
\end{aligned}
$$

Resolvendo a equação acima, chega-se a $3,8 \mathrm{Kg}$ de matéria seca de milho. No caso dos animais semi-confinados, uma quantidade menor de ração é consumida: $1,5 \mathrm{Kg}$ de concentrado por dia por cabeça, com 50 \% de milho na sua composição.

Como, em média, o rebanho confinado e semi-confinado recebe suplementação 120 dias por ano, geralmente nos meses de maio, junho, julho e agosto, em decorrência das condições climáticas desfavoráveis à produção de pasto neste período, o consumo de milho na pecuária de corte ocorre nesta época.

Os dados secundários utilizados foram coletados na FNP - Consultoria \& Comércio.

\subsection{Pecuária de Leite}

Para calcular o consumo de milho na pecuária de leite foram utilizados dois métodos indiretos de estimação. No primeiro, consideram-se dois limites, um representando "baixo" nível de tecnologia e outro, representando "alto" nível. Para o limite inferior, a produção diária foi fixada em 3 litros por cabeça, índice normalmente encontrado em estados e regiões com pouca utilização de técnicas modernas. O limite superior é de 10 litros por cabeça/ dia, nível de produção só alcançado com o uso de suplementação. Assim, a seguinte expressão pode ser utilizada:

$3 y+10 x=$ Média de leite no estado (por cabeça $/$ dia), sendo

$y+x=1$

Onde:

$y=$ percentual do rebanho que não utiliza suplementação;

$\mathrm{x}=$ percentual do rebanho que utiliza suplementação.

\footnotetext{
${ }^{15}$ A matéria seca representa $89 \%$ da composição do milho
} 
A partir dessa expressão, foi possível calcular o percentual do rebanho estadual que consome milho. Considerou-se que uma vaca que produz mais de 10 litros/dia consome $1 \mathrm{Kg}$ de ração a cada 3 litros de leite produzidos. Assim, obtêm-se o consumo de $3,3 \mathrm{Kg}$ de concentrado/dia. A quantidade de matéria seca corresponde a $90 \%$ do concentrado, portanto, o consumo é igual a $3 \mathrm{Kg} / \mathrm{dia}$.

Como visto anteriormente, o percentual da proteína bruta no milho e farelo de soja é $46 \%$ e $9 \%$ respectivamente, e que a ração, deve ser composta por $20 \%$ de proteína. Portanto, um animal tem que ingerir $600 \mathrm{gr}$ de proteína por dia. Ou seja:

$$
\begin{aligned}
& 0,46 S+0,09 M=0,6 \mathrm{Kg} \text { de } \mathrm{PB} \\
& S+M=3 \mathrm{Kg} \text { de } M S \\
& \text { Onde } \quad M=\text { Milho } \\
& S=\text { Soja } \\
& \text { MS = Matéria Seca }{ }^{16}
\end{aligned}
$$

E, portanto, o consumo de Matéria Original de milho/ cabeça/ dia $=2,1 \mathrm{Kg}$ de Matéria Seca $\div 89 \%$ ( $\%$ de matéria seca $)=2,4 \mathrm{Kg}$

O segundo método indireto de medida procurou obter um indicativo do nível de tecnologia. O número de vacas ordenhadas estimado pelo IBGE considera todas as vacas que estão em lactação, inclusive aquelas não especializadas na produção de leite ${ }^{17}$. Assim, foi necessário, primeiro, estimar o percentual das vacas que utilizam suplementação.

A ordenha mecânica é um indicativo do uso de tecnologia. Para tanto, utilizou-se como indicador o percentual do número total de vacas sob ordenha mecânica.

A sazonalidade mensal foi estimada pela venda mensal de ração destinada a esse segmento. Esses dados foram obtidos junto à Associação Nacional de Fabricantes de Ração (ANFAR).

\footnotetext{
${ }_{17}^{16}$ A matéria seca representa $89 \%$ da composição do milho.

${ }^{17}$ Os dados referentes ao número de vacas ordenhadas são disponíveis apenas até o ano de 1997. Para estimar o ano de 1998 utilizou-se a mesma metodologia apresentada no caso de suínos.
} 
A metodologia utilizada pelo IBGE na estimativa do número de vacas ordenhadas foi modificada após o Censo Agropecuário 1995 - 96. Percebe-se, assim, uma distorção nos números. Em 1996 houve queda de 20\% no rebanho, como mostra a figura 10.

Devido a essa distorção, optou-se por utilizar a mesma participação da pecuária de leite no consumo de milho de 1996 nos anos anteriores.

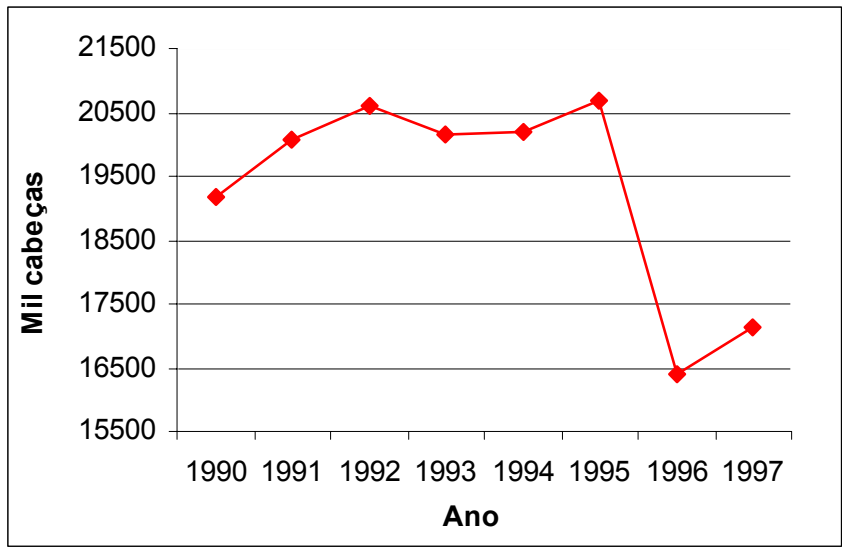

Figura 10 - Vacas ordenhadas em mil cabeças, 1990-1997

Fonte: IBGE, 2000

A produtividade média do leite e o número de vacas ordenhadas foram coletados no Instituto Brasileiro de Geografia e Estatística - IBGE. O percentual de vacas ordenhadas mecanicamente foi obtido do Censo Agropecuário 1995 - 96 do IBGE.

\subsection{Outros animais}

Nesse segmento é considerado o consumo de milho na equinocultura, aquinocultura, cães, gatos e outros.

A produção mensal e estadual de ração destinada a esse setor foi obtida no Sindicato de Rações (SINDIRAÇÕES). 


\subsection{Sementes}

Os dados de produção de sementes registradas, a taxa de utilização dessas sementes e a quantidade utilizada por hectare nos estados estudados foram obtidos na Associação Brasileira dos Produtores de Sementes (ABRASEM). A área plantada foi coletada no IBGE.

1. Consumo de sementes no ano $t=$ (área plantada no ano $\mathrm{t}) \times(\mathrm{Kg} / \mathrm{ha}$ de sementes utilizadas no plantio);

2. Uso de sementes certificadas no ano $t=$ (taxa de utilização de sementes certificadas) $\mathrm{x}$ (consumo de sementes no ano $t$ );

3. Grãos utilizados como sementes no ano $t=$ (consumo de sementes no ano $\mathrm{t}$ ) - (uso de sementes certificadas no ano $\mathrm{t}$ );

4. Quantidade "desaparecida" como semente em $t=$ (produção de sementes certificadas ${ }^{18}+$ grãos utilizados como sementes em $\mathrm{t}$ ) x (sazonalidade mensal da produção de sementes);

\subsection{Consumo Industrial}

Os dados foram obtidos junto à Associação Brasileira das Indústrias de Moagem do Milho (ABIMILHO). Supõe-se que a demanda para esses fins é homogênea ao longo do ano.

\subsection{Perdas}

A parcela da produção de milho sujeita a perda e a quantidade perdida no transporte e na armazenagem foram calculadas a partir do trabalho realizado por Santos \& Mantovani (1997). Ver tabela 6.

\footnotetext{
${ }^{18} \mathrm{O}$ plantio para produção dessas sementes ocorreu no ano $\mathrm{t}_{-1}$ e a colheita, em $\mathrm{t}$.
} 
Tabela 6. Perdas (\%) de grãos na armazenagem e transporte

\begin{tabular}{cc}
\hline Estado & $\%$ de perdas \\
\hline RS & $11,6 \%$ \\
SC & $12,9 \%$ \\
PR & $7,7 \%$ \\
SP & $4,6 \%$ \\
MG & $10,3 \%$ \\
\hline
\end{tabular}

Fonte: Adaptado de EMBRAPA, 1997.

\subsection{Produção}

Os dados de produção doméstica foram obtidos para os estados das regiões Sul e Sudeste (estimativas do IBGE).

\subsection{Comportamento dos Preços: Variação Estacional}

Segundo Hoffmann (1969 e 1991), o comportamento dos preços dos produtos agropecuários contrasta nitidamente com o comportamento dos bens industrializados, sendo que os primeiros apresentam maior variabilidade. Isto se deve, principalmente, à estacionalidade da produção agrícola e pecuária. Sendo assim, os produtores de bens agropecuários são, de maneira geral, passivos à formação dos preços, sujeitando-se ao preço que se estabelece no mercado.

Esses preços exibem uma variação cíclica com o decorrer das estações do ano. $\mathrm{Na}$ época de safra, o preço do produto é relativamente baixo, aumentando depois, até a época em que o suprimento do produto é mínimo.

O conhecimento da variação estacional dos preços do milho é essencial para a previsão do seu preço em determinada época do ano. A obtenção dos índices de variação estacional de preço será realizada a partir do procedimento usado por Hoffmann (1969). Ou seja, utilizando o método da média geométrica móvel. 
Uma série de preços $\left(\mathrm{P}_{\mathrm{t}}\right)$ pode ser considerada o agregado de quatro componentes: Tendência Geral (D), Flutuações Estacionais (S), outras Flutuações Cíclicas (C) e Variações Irregulares (I).

$P_{t}=D_{t}+S_{t}+C_{t}+I_{t}$

$P_{t}$ representa o preço médio do período (mês) t.

Os valores de uma série de preços no tempo será o produto desses componentes:

$P_{t}=D_{t} \cdot S_{t} \cdot C_{t} \cdot I_{t}$

A Tendência Geral (D) resulta de um complexo de causas que, atuando continuamente num mesmo sentido, condicionam o crescimento, a diminuição, ou ainda, a constância no tempo. As Flutuações Estacionais (S) resultam de variações climáticas na maioria dos casos ou de hábitos/preferências dos consumidores. As Flutuações Cíclicas ou de Conjuntura (C) compreendem movimentos devidos a períodos de crise ou depressão e a períodos de prosperidade. Variações Irregulares (I) são causadas por fatores exógenos, incluindo os fatores catastróficos, como guerras, epidemias e fatores aleatórios. (Lange, 1967).

O problema estatístico de determinação do índice de variação estacional consiste em isolar o componente Variações Estacionais (S). O fato de esse componente não ter relações com outras variações e tendências apresentadas pelos mesmos preços facilita seu isolamento.

Lange (1967) parte do pressuposto que as flutuações estacionais são periódicas. Essas flutuações podem ser eliminadas dentro do período de um ano - como no caso do presente trabalho, mês a mês - por meio de média móvel.

Além dos componentes sazonais, a série contém igualmente certas flutuações aleatórias que ocorrem todos os anos. Ao eliminar as flutuações aleatórias, pode-se obter o componente sazonal puro.

Para obtenção dos índices de variação estacional são considerados vários modelos. No presente trabalho serão demonstrados os modelos III e IV ${ }^{19}$ de Hoffmann. Os modelos I (de médias aritméticas) e II (de médias geométricas) não levam em conta a existência de

\footnotetext{
${ }^{19}$ Os demais modelos podem ser vistos em Hoffmann, 1969.
} 
tendências de variação de longo-prazo, enquanto os que serão demonstrados a seguir consideram essas tendências. Será utilizado no presente trabalho o modelo IV, pois como justifica Hoffmann (1969, p.18), "é o que melhor serve de base teórica para a determinação do componente estacional das variações dos preços dos produtos agropecuários". Nesse modelo o componente estacional apresenta periodicidade relativa, isto é, só é obtida uma variável periódica quando se divide o preço $P_{t}$ pela média móvel apropriada.

De acordo com Hoffmann (1969):

..."No modelo III o componente estacional $\left(\mathrm{X}_{\mathrm{ij}}\right)$ é somado a uma média aritmética móvel que varia linearmente em função do tempo. Os preços mensais $P_{i j}$ (sendo $i=1,2, \ldots, N$ o ano e j $=1,2, \ldots, 12$ o mês) são dados pela função

$$
P_{i j}=A+B[12(i-1)+j]+X_{i j}
$$

onde $\sum_{j=1}^{12} X_{i j}=0$, A e B são constantes, $t=12(i-1)+j$

Para obter os valores do componente estacional $X_{i j}$ deve-se subtrair de cada $P_{i j}$ a média aritmética móvel centralizada correspondente.

Fazendo $12(\mathrm{i}-1)+\mathrm{j}=\mathrm{t}$, temos a função (1) igual a

$P_{t}=A+B t+X_{t}$

A correspondente média aritmética móvel centralizada é definida pela

$$
M_{t}=\frac{0,5 P_{t-6}+P_{t-5}+\mathrm{K}+P_{t}+\mathrm{K}+P_{t+5}+0,5 P_{t+6}}{12}
$$

Substituindo (1) em (2) e simplificando obtem-se

$$
M t=\frac{12 \mathrm{~A}+0,5 \mathrm{~B}(\mathrm{t}-6)+\mathrm{B}(\mathrm{t}-5)+\ldots+\mathrm{Bt}+\ldots+\mathrm{B}(\mathrm{t}+5)+0,5 \mathrm{~B}(\mathrm{t}+6)+\sum_{j=1}^{12} X_{i j}}{12}
$$

$M_{t}=A+B t$

Subtraindo $M_{t}$ de $P_{t}$ chega-se a $X_{t}$. 
No Modelo IV, o componente estacional $\left(\mathrm{X}_{\mathrm{ij}}\right)$ é multiplicado por uma média geométrica móvel que varia exponencialmente em função do tempo. A função que representa esse modelo é

$$
P_{t}=B^{t} X_{i j}
$$

onde $\prod_{j=1}^{12} x_{i j}=1$, A e B são constantes, $t=12(i-1)+j$

Aplicando logaritmos à expressão (4), verifica-se que o modelo IV se transforma no modelo III desde que se trabalhe com os logaritmos das variáveis.

$$
\log P t=\log A+t \log B+\log X_{i j}
$$

onde $\sum_{j=1}^{12} X_{i j}=0$

No modelo IV, o componente estacional $\left(X_{i j}\right)$ é obtido dividindo os preços $P_{t}$ pela média geométrica móvel centralizada, que pode ser assim expressa:

$$
G_{T}=\sqrt[K]{P_{T-\lambda}^{0,5} \times P_{T-\lambda+1} \Lambda P_{T} \Lambda P_{T+\lambda-1} \times P_{T+\lambda}^{0,5}}
$$

Onde $\mathrm{K}=12=2 \lambda$

Obtidas as médias geométricas móveis centralizadas, o próximo passo é a determinação dos índices estacionais de cada período. Para obtenção dos índices mensais deve-se dividir cada preço pela respectiva média geométrica móvel centralizada.

Tem-se, então, os índices mensais em número de 12 . (n-1) onde $n=n^{\circ}$ anos da série. Assim, têm-se para cada mês ( $n-1)$ e o passo seguinte é a obtenção da média geométrica dos índices estacionais para cada mês . Para janeiro, por exemplo, temos

$$
\bar{I}_{j a n} .=\sqrt[n]{\prod I_{j a n}}
$$

ou 


$$
\log \bar{I}_{j a n}=\frac{1}{n-1}\left(\sum \log I_{j a n}\right)
$$

Se a média geométrica dessas médias calculadas não é igual a 100 , elas serão ajustadas pelo fator de correção $(F)$ cuja expressão matemática é :

$$
\mathrm{F}=\frac{100}{\sqrt[12]{\prod_{j=1}^{12} \bar{I}}}
$$

O "índice sazonal " $\left(\hat{E}_{\mathrm{j}}\right)$ ou índice estacional puro, para os doze meses do ano, é determinado pelo produto das duas últimas expressões, isto é:

$$
\hat{\mathrm{E}}_{\mathrm{j}}=\bar{I} \cdot \mathrm{F}
$$

Para verificar a dispersão dos índices estacionais em torno de sua média calcula-se o erro padrão (s) dos índices de variação estacional através de

$$
S_{j a n}=\sqrt{\frac{\sum\left(\log I_{j a n}-\log \bar{I}_{j a n}\right)^{2}}{n-1}}
$$

para o mês de janeiro, por exemplo.110

O índice de irregularidade é definido como sendo o antilogarítmo do erro padrão. Os limites do intervalo de confiança, superior e inferior, são obtidos multiplicando e dividindo o índice sazonal pelo índice de irregularidade, respectivamente."

Os dados de preços foram obtidos na CONAB e deflacionados pelo IGP-DI da Fundação Getúlio Vargas (base agosto 1994; atualização dezembro 1998). 


\section{RESULTADOS E DISCUSSÃO}

\subsection{Resultados das Pesquisas de Campo}

\subsubsection{Avicultura de Corte}

Foram realizadas 25 entrevistas no campo para esse segmento, sendo 13 para categoria frango; 6 , para matrizes em recria e 6 , para matrizes em produção.

Os índices utilizados nas avós são os mesmos das matrizes. Não foi possível realizar visitas a avozeiros por integrarem um setor extremamente "fechado". Além disso, o consumo dessa categoria é muito pequeno, representando, em média, 0,16 \% do consumo de milho no segmento.

Todas as respostas do índice quantidade de fêmeas utilizadas para cada macho na avicultura de corte e postura foram iguais, ou seja, um macho para dez fêmeas.

O quadro 1 mostra a média e o desvio - padrão obtidos na pesquisa de campo. Os desvios - padrões da categoria frango são pequenos. Assim, acredita-se em um resultado do consumo de milho para a avicultura de corte próximo da realidade. Essa categoria representa $90 \%$ do consumo de milho do segmento avicultura de corte.

Como as categorias matrizes e galos em recria e produção participam com apenas $2,6 \%$ do consumo, espera-se que os altos desvios - padrões do índice consumo de ração não alterem significativamente os resultados. 


\begin{tabular}{|l|c|c|}
\hline \multirow{2}{*}{ Índice zootécnico } & \multicolumn{2}{c|}{ Resultado } \\
\cline { 2 - 3 } & & Média \\
\hline Frangos & 46 dias & 1,81 \\
\hline Idade de abate & $94 \mathrm{gr} / \mathrm{dia}$ & 11 \\
\hline Consumo de ração & $63 \%$ & 3,96 \\
\hline Participação do milho na composição da ração & $4 \%$ & 0 \\
\hline Taxa de mortalidade & & 11 \\
\hline Matrizes em recria & 168 dias & 0,5 \\
\hline Maturidade sexual & $4 \%$ & 21 \\
\hline Taxa de mortalidade & $66 \mathrm{gr} / \mathrm{dia}$ & 6,1 \\
\hline Consumo de ração & $58 \%$ & \\
\hline Participação do milho na composição da ração & & 0 \\
\hline Galos em recria & 10 & 21 \\
\hline Número de fêmeas utilizadas por macho $\left.{ }^{*}\right)$ & $66 \mathrm{gr} / \mathrm{dia}$ & 6,1 \\
\hline Consumo de ração & $58 \%$ & 1,45 \\
\hline Participação do milho na composição da ração & & 21,69 \\
\hline Matrizes em produção & 14,48 & 3,77 \\
\hline Número de pintos produzidos por matriz & $158 \mathrm{gr} / \mathrm{dia}$ & \\
\hline Consumo de ração & $62 \%$ & 34,9 \\
\hline Participação do milho na composição da ração & & 2,99 \\
\hline Galos em produção & $140 \mathrm{gr} / \mathrm{dia}$ & \\
\hline Consumo de ração & $62 \%$ & 1,45 \\
\hline Participação do milho na composição da ração & & 21,69 \\
\hline Avós & 7,2 & 3,77 \\
\hline Número de matrizes produzidas por avó $\left.{ }^{*}{ }^{*}\right)$ & $158 \mathrm{gr} / \mathrm{dia}$ & 2,99 \\
\hline Consumo de ração & $62 \%$ & $\mathrm{gr} / \mathrm{dia}$ \\
\hline Participação do milho na composição da ração & $62 \%$ & \\
\hline Avós galos & & \\
\hline Consumo de ração & & \\
\hline Participação do milho na composição da ração & & \\
\hline
\end{tabular}

Quadro 1. Resultado da pesquisa de campo, avicultura de corte, 1999/2000

Fonte: Dados da pesquisa.

${ }^{*}$ Esse índice é igual para todas as categorias de galos de corte e postura.

$\left.{ }^{(*}\right)$ Uma avó produz, em média, 17 ovos por mês; destes 14,48 eclodem. Como 50\% correspondem as fêmeas, concluise que uma avó produz 7,2 matrizes por mês.

\subsubsection{Avicultura de Postura}

Foram realizadas 20 entrevistas com pessoas ligadas à avicultura de postura, sendo 8 para categoria comerciais em produção; 7, para comerciais em recria; 4, para matrizes em produção e 1, para matrizes em recria. 
No caso de matrizes e galos em recria apenas 1 questionário foi respondido, mas isso não compromete os resultados, pois o consumo de milho dessa categoria representa aproximadamente $0,5 \%$ do consumo da avicultura de postura.

\begin{tabular}{|c|c|c|c|c|}
\hline \multirow{3}{*}{ Índice zootécnico } & \multicolumn{4}{|c|}{ Resultado } \\
\hline & \multicolumn{2}{|c|}{ Ovo Branco } & \multicolumn{2}{|c|}{ Ovo Vermelho } \\
\hline & Média & $\begin{array}{l}\text { Desvio } \\
\text { padrão }\end{array}$ & Média & $\begin{array}{l}\text { Desvio } \\
\text { padrão }\end{array}$ \\
\hline \multicolumn{5}{|l|}{ Poedeiras comerciais em produção } \\
\hline Consumo de ração por ovo & $139 \mathrm{gr} /$ ovo & 14 & $140 \mathrm{gr} /$ ovo & 9,7 \\
\hline $\begin{array}{l}\text { Participação do milho na composição } \\
\text { da ração }\end{array}$ & $62 \%$ & 1,4 & $63 \%$ & 3,1 \\
\hline \multicolumn{5}{|l|}{ Poedeiras comerciais em recria } \\
\hline Taxa de mortalidade & $2,5 \%$ & 0,51 & $2,7 \%$ & 0,6 \\
\hline $\begin{array}{l}\text { Idade em que as poedeiras começam } \\
\text { produzir ovos comerciais }\end{array}$ & 134 dias & 8,8 & 134 dias & 8,8 \\
\hline Consumo de ração/ cabeça & $49,4 \mathrm{gr} / \mathrm{dia}$ & 3,1 & $54 \mathrm{gr} / \mathrm{dia}$ & 2 \\
\hline $\begin{array}{l}\text { Participação do milho na composição } \\
\text { da ração }\end{array}$ & $62 \%$ & 1,78 & $60 \%$ & 2,1 \\
\hline \multicolumn{5}{|l|}{ Matrizes em recria } \\
\hline Idade da maturidade sexual & 184 dias & & 184 dias & \\
\hline Consumo de ração/ cabeça & $55 \mathrm{gr} / \mathrm{dia}$ & & $60 \mathrm{gr} / \mathrm{dia}$ & \\
\hline $\begin{array}{l}\text { Participação do milho na composição } \\
\text { da ração }\end{array}$ & $60 \%$ & & $60 \%$ & \\
\hline \multicolumn{5}{|l|}{ Matrizes em produção } \\
\hline $\begin{array}{l}\text { Número de comerciais poedeiras } \\
\text { produzidas por matriz }\end{array}$ & 10,15 & 2,1 & 10,15 & 2,1 \\
\hline Consumo de ração/ cabeça & $123 \mathrm{gr} / \mathrm{dia}$ & 5,8 & $125 \mathrm{gr} / \mathrm{dia}$ & 5 \\
\hline $\begin{array}{l}\text { Participação do milho na composição } \\
\text { da ração }\end{array}$ & $62 \%$ & 2,9 & $62 \%$ & 2,9 \\
\hline \multicolumn{5}{|l|}{ Avós } \\
\hline $\begin{array}{l}\text { Número de matrizes produzidas por } \\
\text { avó }\end{array}$ & 10,15 & 2,1 & 10,15 & 2,1 \\
\hline Consumo de ração/ cabeça/ dia & $123 \mathrm{gr} / \mathrm{dia}$ & 5,8 & $125 \mathrm{gr} / \mathrm{dia}$ & 5 \\
\hline $\begin{array}{l}\text { Participação do milho na composição } \\
\text { na ração }\end{array}$ & $62 \%$ & 2,9 & $62 \%$ & 2,9 \\
\hline
\end{tabular}

Quadro 2. Resultado da pesquisa de campo, avicultura de postura, 1999/2000

Fonte: Dados da pesquisa

(*) Uma matriz produz, em média, 23,8 ovos por mês, destes 20,31 eclodem e são aproveitados. Como $50 \%$ correspondem as fêmeas, concluí-se que uma avó produz 10,15 matriz por mês. 


\subsubsection{Suinocultura}

Foram realizadas 37 entrevistas no sistema tecnificado. No caso do sistema tradicional, os índices foram fornecidos por 2 técnicos do setor, um médico veterinário que presta serviços a cerca de 20 produtores de baixa tecnologia na região de São Paulo e um vendedor de insumos. Os produtores tradicionais não são cadastrados nas associações do setor, portanto houve dificuldade em localizá-los.

As perguntas do questionário sobre o tamanho do rebanho e o número de cabeças abatidas anualmente possibilitam saber a taxa de desfrute. Esse índice permite identificar o tipo de produtor entrevistado.

A taxa de desfrute brasileira é baixa quando comparada às dos principais países produtores. Nos Estados Unidos, por exemplo, onde a produção de suínos é altamente tecnificada, a taxa de desfrute em 1989 chegava a 160\%. No Brasil, em 1997, essa taxa era de apenas $70 \%$.

Nesse estudo, constatou-se que a média da taxa de desfrute dos produtores entrevistados é $220 \%$. Percebe-se, então, que os produtores entrevistados atingiram média bastante satisfatória e, portanto, podem ser considerados produtores tecnificados. 


\begin{tabular}{|c|c|c|c|}
\hline \multirow{3}{*}{ Índice zootécnica } & \multicolumn{3}{|c|}{ Resultado } \\
\hline & \multicolumn{2}{|c|}{ Tecnificado } & \multirow{2}{*}{$\begin{array}{c}\text { Tradicional } \\
\text { Média }\end{array}$} \\
\hline & Média & $\begin{array}{l}\text { Desvio } \\
\text { padrão }\end{array}$ & \\
\hline \multicolumn{4}{|l|}{ Suínos } \\
\hline Rendimento da carcaça & $78 \%$ & 3,6 & $70 \%$ \\
\hline Idade do abate & 154,3 dias & 10 & 365 dias \\
\hline Conversão Alimentar & 2,84 & 0,26 & 9,00 \\
\hline Participação do milho na composição da ração & $64 \%$ & 13 & $31 \%$ \\
\hline Taxa de desfrute & $220 \%$ & 61 & $30 \%$ \\
\hline \multicolumn{4}{|l|}{ Matrizes } \\
\hline Número de leitões terminados por porca & 21 & 1,7 & 11 \\
\hline Consumo de ração & 3,0 & 0,527 & 3,0 \\
\hline Participação do milho na composição da ração & $61 \%$ & 9,9 & $31 \%$ \\
\hline \multicolumn{4}{|l|}{ Cachaços } \\
\hline Número de matrizes utilizadas por cachaço ${ }^{\left({ }^{*}\right)}$ & 35 & 44 & 13 \\
\hline Consumo de ração & 2,29 & 0,41 & 2,29 \\
\hline Participação do milho na composição da ração & $61 \%$ & 10 & $31 \%$ \\
\hline
\end{tabular}

Quadro 3. Resultado da pesquisa de campo, suinocultura, 1999/2000

Fonte: Dados da pesquisa

${ }^{(*)}$ Alguns produtores tecnificados têm poucos reprodutores porque utilizam inseminação artificial. A proporção fêmea por macho varia de 80 a 140. No caso daqueles produtores que não utilizam a inseminação, essa proporção cai para 13 fêmeas. Isso explica o alto desvio-padrão encontrado.

\subsubsection{Pecuária de Leite e Corte}

Percebeu-se no teste dos questionários, principalmente na pecuária de leite, que produtos substitutos são utilizados, dependendo dos preços relativos. Como quantificar os substitutos não era objetivo deste trabalho. Optou-se por não aplicar os questionários e estimar o consumo potencial do milho na composição da ração utilizando apenas os dois produtos principais exigidos na dieta alimentar: soja e milho.

Para a pecuária de leite, como mencionado anteriormente, utilizaram-se dois métodos de estimação. O primeiro método baseado nos limites inferior e superior de produtividade, mostrou-se muito suscetível a pequenas mudanças no limite inferior, ou seja, diferenças de décimos nesse limite causam alterações bruscas nos resultados. 
Optou-se por utilizar o segundo método, fundamentado na participação relativa da ordenha mecânica nas vacas em lactação. Deve-se ressaltar, porém, que o percentual de vacas que são ordenhadas mecanicamente foi estimado para o ano de 1996. Portanto, algumas alterações nos anos anteriores e posteriores podem não ter sido captadas.

\subsection{Consumo de Milho}

Os dados referentes ao consumo de milho estão expostos no Anexo A.

\subsubsection{Avicultura de Corte}

O Sul é a maior região produtora de aves de corte do Brasil. Em 1998 participou com $53 \%$ do total nacional de pintos alojados. O Sudeste vem em segundo lugar (31\%), tendo o estado de São Paulo como principal produtor e, consequentemente, maior consumidor de milho, representando $22,7 \%$ do consumo total de milho na avicultura de corte nas regiões Sul e Sudeste.

O consumo de milho nesse setor cresceu $76 \%$ no Sul e $51 \%$ no Sudeste nos anos 90 . O Rio Grande do Sul foi o estado que apresentou maior crescimento, qual seja de 748 mil toneladas em 1990 para 1.513 mil toneladas em 1998. As figuras 11 e 12 mostram a evolução do consumo estadual no Sul e Sudeste.

Como já mencionado, os frangos são os principais consumidores de milho desse segmento, ou seja, respondem por $90 \%$ do consumo. Em seguida vêm as matrizes e galos em produção com $8 \%$; matrizes e galos em recria, $1,6 \%$ e avós, $0,2 \%$. 


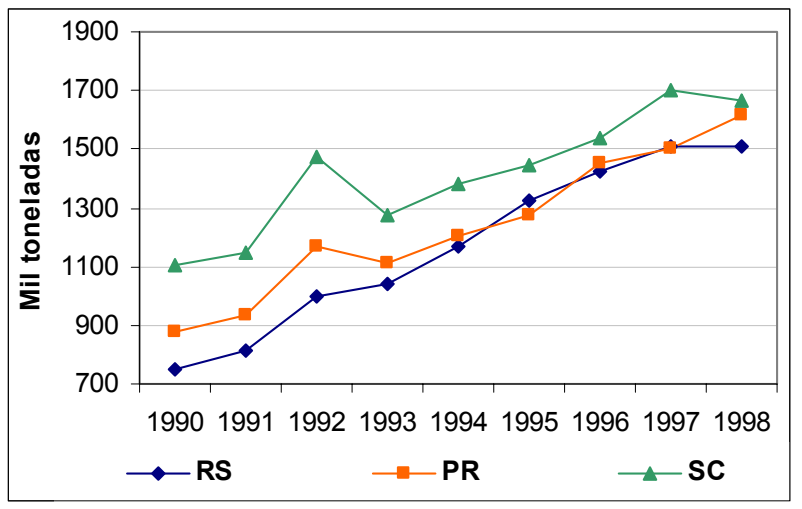

Figura 11 - Consumo de milho na avicultura de corte do Rio Grande do Sul, Paraná e Santa Catarina, $1990-1998$

Fonte: Estimativa do autor

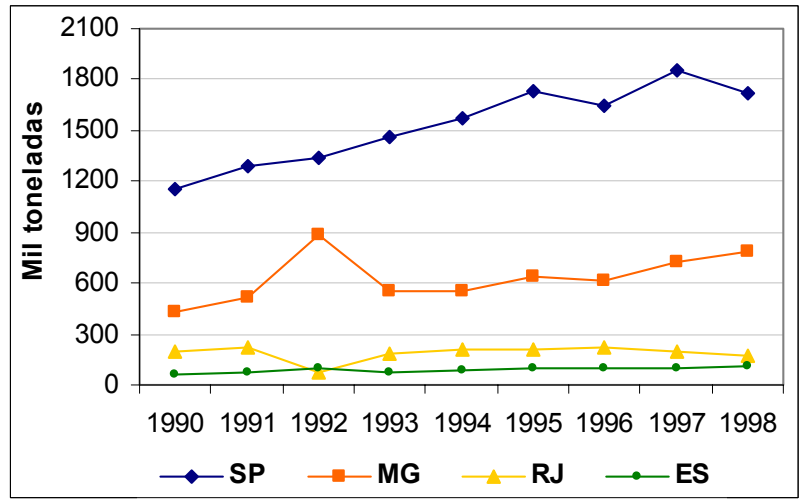

Figura 12 - Consumo de milho na avicultura de corte de São Paulo, Minas Gerais, Rio de Janeiro e Espirito do Santo, 1990 - 1998

Fonte: Estimativa do autor 


\subsubsection{Avicultura de Postura}

A produção de ovos se concentra nas regiões Sudeste $(55 \%)$ e Sul $(18 \%)$ do país. Como ilustra a figura 13, o consumo de milho ficou estagnado durante o período estudado, pois não houve aumento da produção de ovos.

São Paulo é o maior responsável pelo consumo na avicultura de postura. Sua participação é de $56 \%$, vindo a seguir Minas Gerais (13\%), Paraná (12\%) e Rio Grande do Sul (10\%). Ver figura 14.

As aves produtoras de ovos vermelhos, apesar de consumirem maior quantidade de ração per capita, constituem um plantel menor que o de aves produtoras de ovos brancos. Assim sendo, este último plantel, é responsável por $71 \%$ do consumo de milho.

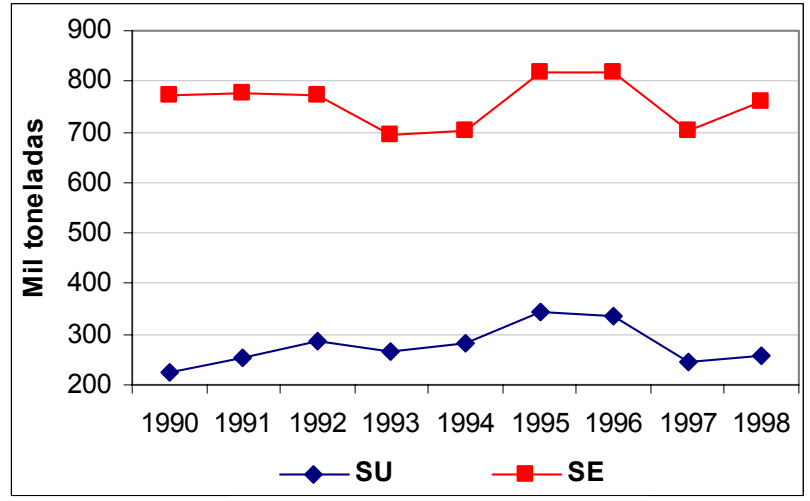

Figura 13 - Consumo de milho na avicultura de postura nas regiões Sul e Sudeste do Brasil, $1990-1998$

Fonte: Estimativa do autor 


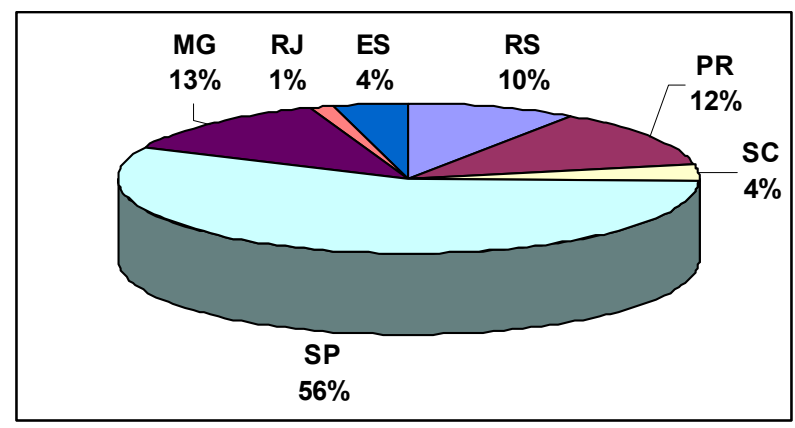

Figura 14 - Participação dos estados das regiões Sul e Sudeste do Brasil na avicultura de postura, 1998

Fonte: Estimativa do autor.

\subsubsection{Suinocultura}

O consumo de milho na suinocultura das regiões Sul e Sudeste foi de 4,358 milhões de toneladas em 1998. Os estados do Sul são os maiores consumidores: $82 \%$ do total.

O consumo cresceu $72 \%$ no Sul e $63 \%$ no Sudeste. Os estados de Minas Gerais e o Rio Grande do Sul apresentaram os maiores incrementos, $98 \%$ e $92 \%$ respectivamente.

Esse crescimento se deu por diferentes motivos. No Rio Grande do Sul o aumento do consumo de milho ocorreu devido ao acréscimo de $10 \%$ no rebanho de suínos e ao aumento da participação da produção em sistemas tecnificados, de $22.3 \%$ em 1990, para 54\% em 1998. Em Minas Gerais o crescimento do consumo deu-se apenas pelo aumento da participação do sistema tecnificado, visto que o rebanho de suínos diminuiu $21 \%$.

Em Santa Catarina o consumo cresceu $71 \%$, com aumento significativo do rebanho. Vale destacar que, desde 1990, Santa Catarina é o único estado onde $70 \%$ (ou mais) da produção de suínos ocorre em sistemas tecnificados. As figuras 15 e 16 mostram a evolução do consumo estadual na suinocultura. 


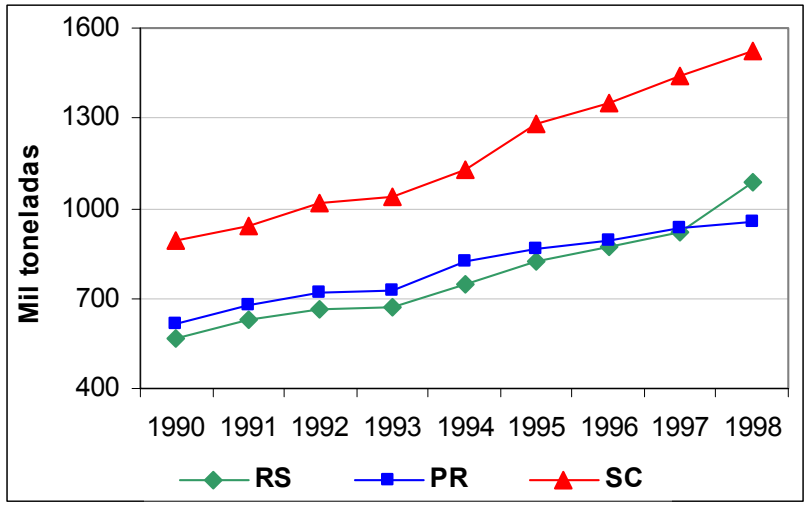

Figura 15 - Consumo de milho na suinocultura do Rio Grande do Sul, Paraná e Santa Catarina, $1990-1998$

Fonte: Estimativa do autor

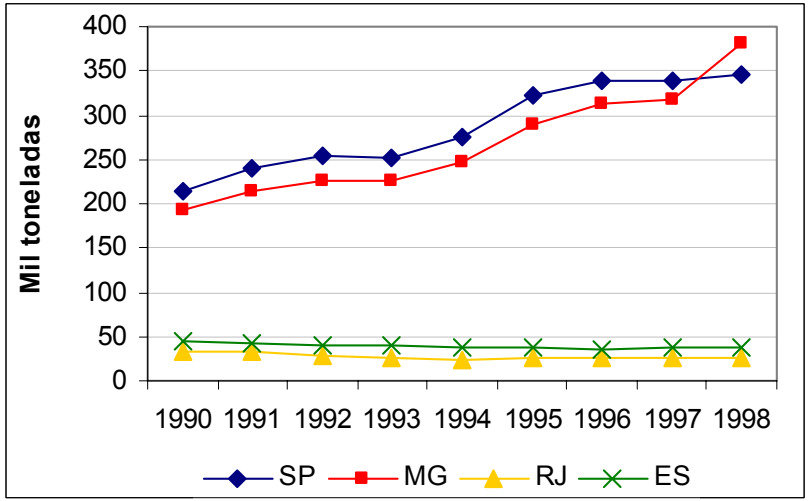

Figura 16 - Consumo de milho na suinocultura de São Paulo, Minas Gerais, Rio de Janeiro e Espirito do Santo, 1990 - 1998

Fonte: Estimativa do autor

\subsubsection{Pecuária de Corte}

O rebanho confinado e semi-confinado de bovinos está concentrado nas regiões Centro-Oeste (38\%) e Sudeste (30\%). Esse segmento da pecuária consumiu, em 1998, 463 mil 
toneladas de milho nos estados do Sul e Sudeste. O acréscimo desse consumo foi de $71 \%$. Ver figura 17.

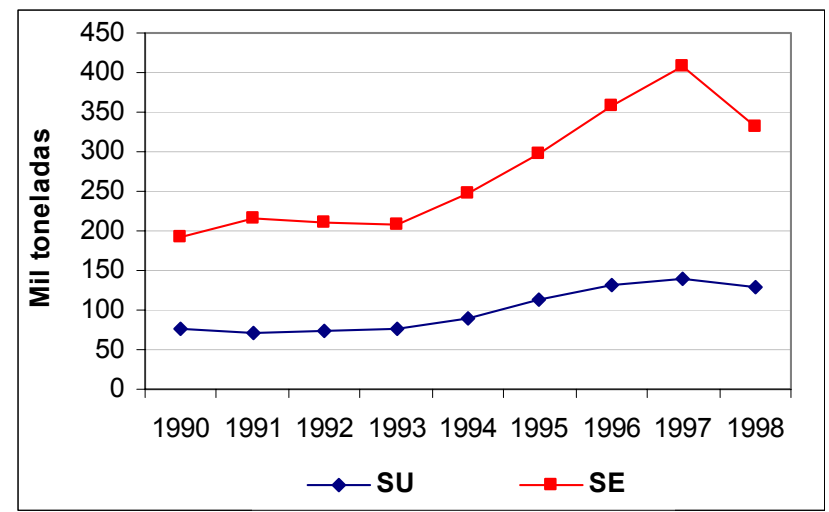

Figura 17 - Consumo de milho na pecuária de corte nas regiões Sul e Sudeste do Brasil, 1990 1998

Fonte: Estimativa do autor

\subsubsection{Pecuária de Leite}

O consumo de milho na pecuária de leite, em 1998, foi de 1,35 milhão de toneladas nas regiões Sul e Sudeste. Esse consumo é distribuído entre os estados da seguinte maneira: Minas Gerais (31\%), Rio Grande do Sul (25\%), São Paulo (17\%), Paraná (13\%), Santa Catarina (10\%), Rio de Janeiro (3\%) e Espirito Santo (2\%).

Face às dificuldades de mensuração, apontadas no Capítulo 4, os resultados relativos à pecuária de leite devem ser interpretados com a devida cautela.

\subsubsection{Outros Animais}

A quantidade de milho consumida por outros animais vem aumentando significativamente ao longo dos anos. Nas regiões Sul e Sudeste, o consumo passou de 236 mil 
toneladas de milho, em 1990, para 831 mil toneladas, em 1998 (figura 18). A participação dos estados no consumo pode ser vista na figura 19.

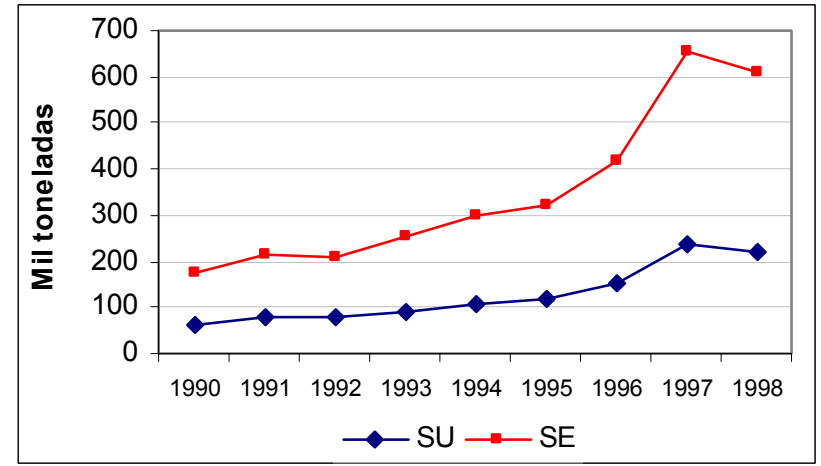

Figura 18 - Consumo de milho dos outros animais nas regiões Sul e Sudeste do Brasil, 1990 1998

Fonte: Estimativa do autor

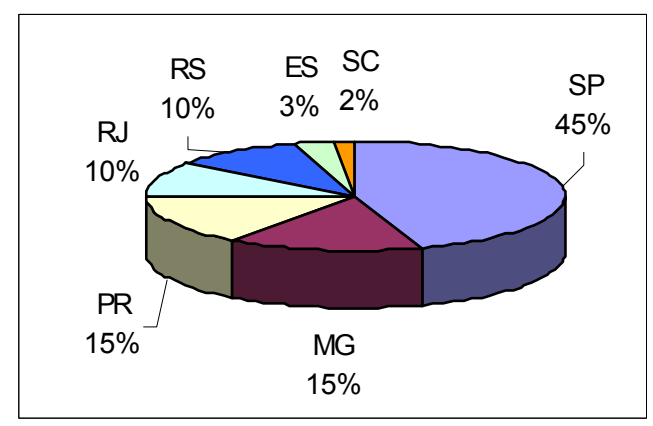

Figura 19 - Participação dos estados das regiões Sul e Sudeste do Brasil em outros animais, 1998

Fonte: Estimativa do autor 


\subsubsection{Industrial}

Os estados de São Paulo e Paraná são responsáveis por $62 \%$ do consumo de milho do Brasil destinado à indústria (figura 20). O consumo das regiões Sul e Sudeste se manteve constante no período de 1994 a 1998, permanecendo ao redor de 3,18 milhões de toneladas.

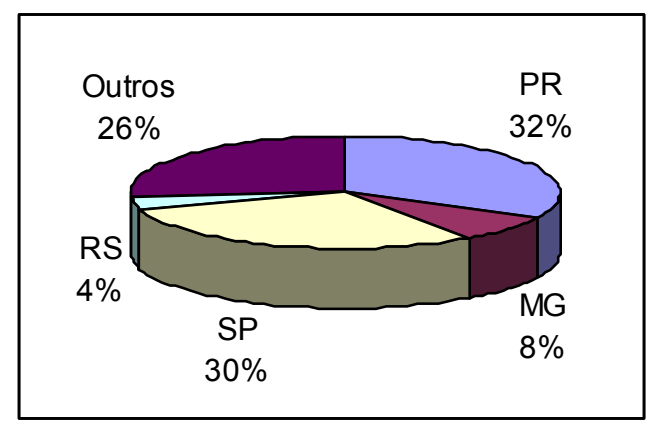

Figura 20 - Participação do consumo de milho na indústria no Brasil, 1998

Fonte: ABIMILHO, 1998

\subsubsection{Sementes}

Os resultados mostrados na tabela 6 indicam a quantidade de milho utilizada como semente. A produção de milho da região Sul é maior que no Sudeste, porém a quantidade de grãos que "desaparece" como semente é menor na região Sul. Isso ocorre porque o Sudeste produz quantidade maior de sementes certificadas. Em 1998, por exemplo, o Sudeste produziu 80,8 mil toneladas de sementes certificadas, enquanto o Sul apenas 45 mil toneladas.

No período, as estatísticas da tabela 7 revelam que o consumo na forma de sementes oscilou entre 157 e 200 mil toneladas. 
Tabela 7. Consumo de sementes em mil toneladas nos estados das regiões Sul e Sudeste do Brasil, 1990 - 1998

\begin{tabular}{lccccccccc}
\hline & 1990 & 1991 & 1992 & 1993 & 1994 & 1995 & 1996 & 1997 & 1998 \\
\hline Sul & 60 & 68 & 67 & 76 & 74 & 90 & 71 & 72 & 60 \\
RS & 18 & 18 & 18 & 21 & 25 & 26 & 22 & 19 & 13 \\
SC & 27 & 34 & 32 & 38 & 37 & 49 & 40 & 44 & 42 \\
PR & 14 & 15 & 17 & 17 & 13 & 15 & 9 & 9 & 5 \\
Sudeste & 114 & 98 & 94 & 98 & 88 & 110 & 97 & 101 & 97 \\
SP & 71 & 50 & 48 & 48 & 42 & 57 & 36 & 40 & 33 \\
MG & 42 & 47 & 45 & 49 & 45 & 53 & 61 & 60 & 63 \\
RJ & 0 & 0 & 0 & 0 & 0 & 0 & 0 & 0 & 0 \\
ES & 1 & 1 & 1 & 1 & 1 & 1 & 0 & 0 & 0 \\
\hline Total & 174 & 166 & 161 & 174 & 162 & 200 & 168 & 173 & 157 \\
\hline
\end{tabular}

Fonte: Estimativa do autor

\subsubsection{Total Geral}

Em 1990, a participação da avicultura de corte no consumo de milho era de $37 \%$. Em 1998, essa participação atingiu $41 \%$. Ver as figuras 21 e 22 . A suinocultura e outros animais apresentaram acréscimos menores. Ambos aumentaram em $2 \%$ sua participação.

Por outro lado, a avicultura de postura e a indústria perderam importância relativa. No primeiro caso, a participação caiu 3 pontos percentuais e, no segundo, 5 pontos. 


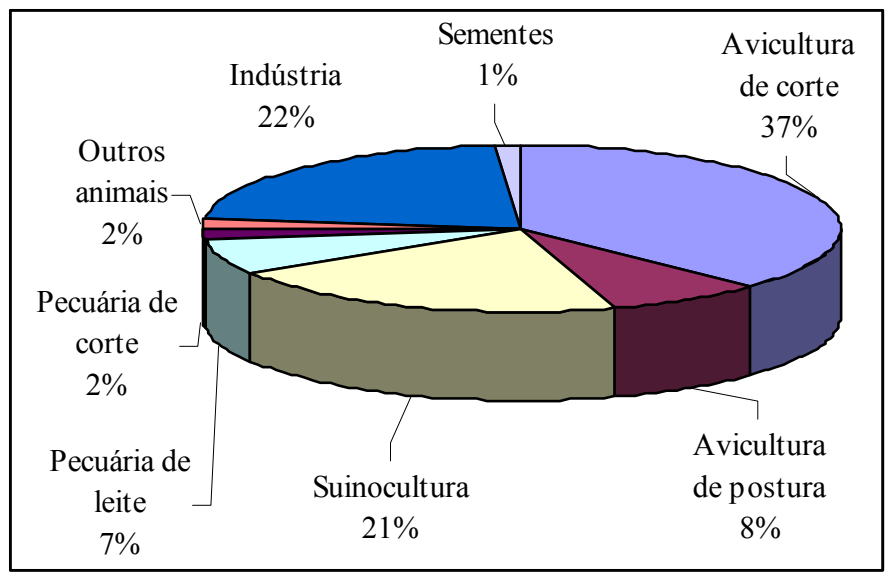

Figura 21 - Participação dos segmentos que consomem milho nas regiões Sul e Sudeste, 1990

Fonte: Estimativa do autor

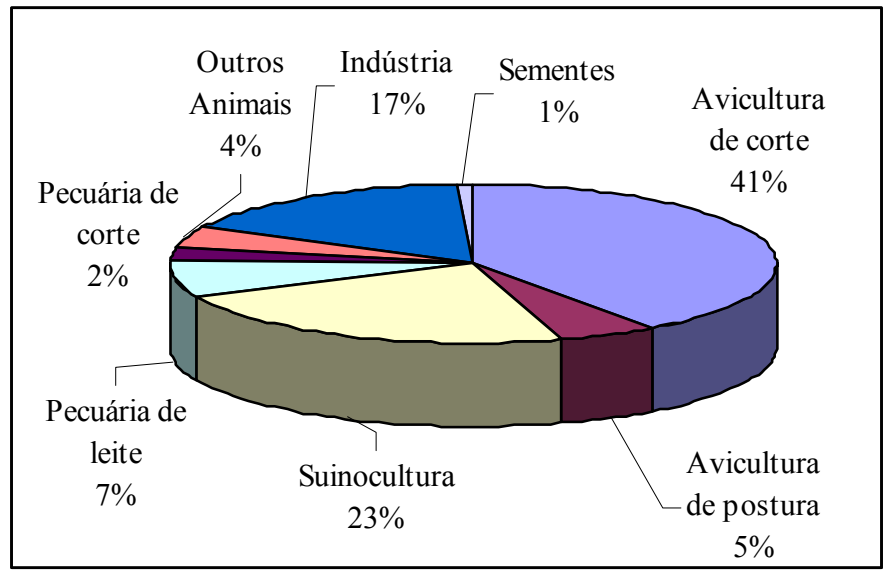

Figura 22 - Participação dos segmentos que consomem milho nas regiões Sul e Sudeste, 1998

Fonte: Estimativa do autor

O consumo de milho, na região Sul, aumentou 63\% no período de 1990 a 1998 e na região Sudeste, $42 \%$.Ver a figura 23. No caso da região Sul, o maior responsável por esse aumento foi o Rio Grande do Sul e no Sudeste, Minas Gerais. Esses dois estados apresentaram acréscimos de $90 \%$ e $50 \%$ respectivamente. Isso explica o motivo pelo qual o estado do Rio Grande do Sul aumentou sua participação no consumo total, como pode ser visto 
nas figuras 24 e 25. São Paulo perdeu 3 pontos percentuais. Os demais estados não apresentaram mudanças significativas.

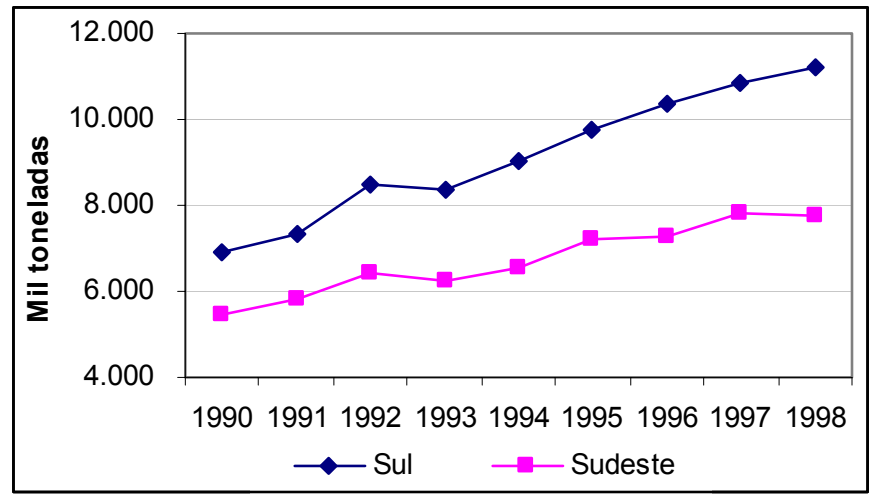

Figura 23 - Consumo de milho nas regiões Sul e Sudeste, 1990-1998

Fonte: Estimativa do autor

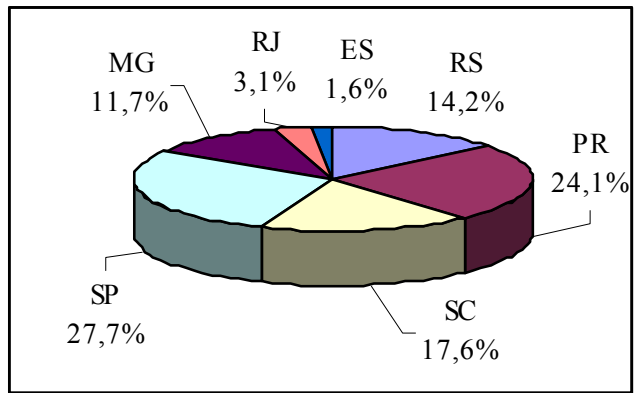

Figura 24 - Participação no consumo de milho dos estados das regiões Sul e Sudeste, 1990

Fonte: Estimativa do autor 


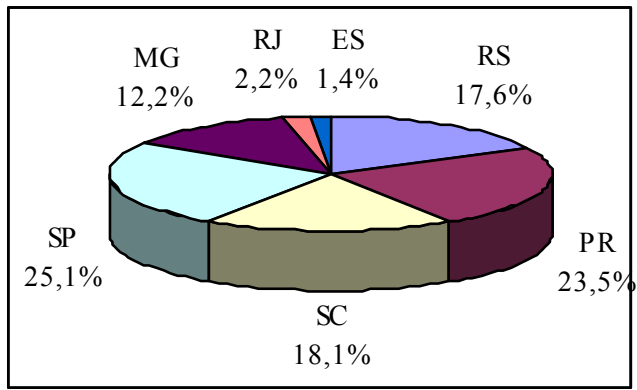

Figura 25 - Participação no consumo de milho dos estados das regiões Sul e Sudeste, 1998

Fonte: Estimativa do autor

\subsubsection{Perdas}

Quando são focalizadas as perdas no transporte e armazenagem do milho, Santa Catarina e Rio Grande do Sul atingem as maiores médias anuais. Como pode ser visto na figura 26 , o índice de perda anual encontrado nesses estados foi em torno de $12 \%$ da produção total. No caso de São Paulo, esse índice cai para 4\%. O total de milho perdido nas regiões Sul e Sudeste, em 1998, foi de 1,97 milhão de toneladas. Isso representa $8,84 \%$ da produção.

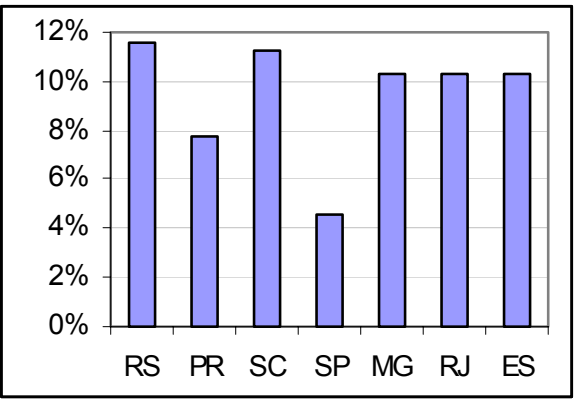

Figura 26 - Participação das perdas em armazenagem e transporte na produção de milho nos estados das regiões Sul e Sudeste

Fonte: IBGE. 1999. EMBRAPA, 1997. 


\subsection{Análise dos Déficits e Excedentes ao Longo do Ano}

A figura 27 mostra a média da produção e do consumo de milho nos estados das regiões Sul e Sudeste no período de 1990 a 1998. O Paraná é o estado que apresenta maior excedente, seguido de Rio Grande do Sul e Minas Gerais. Por outro lado, São Paulo é o maior deficitário.

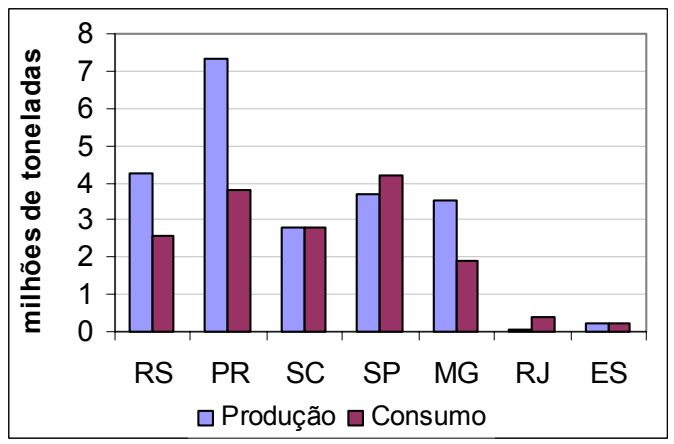

Figura 27 - Produção e consumo de milho: média de 1990/98, Sul e Sudeste

Fonte: IBGE, 1999. Estimativa do autor.

A tabela 8 mostra os estados que são normalmente exportadores ou importadores líquidos de milho. Os números foram obtidos a partir da diferença do percentual estadual do consumo e da produção. Números positivos sugerem que o estado precisou importar no período e números negativos significam que o estado exportou.

Vale ressaltar que no presente trabalho não foi possível quantificar o autoconsumo, porque inexistem dados sobre o comércio interestadual do milho. Portanto, uma parcela do consumo não está sendo quantificada. Assim, os resultados mostram que os déficits estimados são "proxies" das quantidades mínimas importadas de outros estados.

Aqueles estados que apresentaram um pequeno excedente podem na verdade ser, dependendo do tamanho do autoconsumo, importadores líquidos. 
Tabela 8. Percentual do consumo menos o percentual da produção dos estados da região Sul e Sudeste do Brasil, 1990 a 1998

\begin{tabular}{lrrrrrrrrrr}
\hline & 1990 & 1991 & 1992 & 1993 & 1994 & 1995 & 1996 & 1997 & 1998 & Média \\
\hline RS & $-9,0$ & 2,3 & $-8,0$ & $-3,7$ & $-4,2$ & $-5,7$ & 2,4 & $-1,2$ & $-2,4$ & $-3,4$ \\
PR & $-6,2$ & $-5,3$ & $-6,1$ & $-9,8$ & $-10,4$ & $-10,1$ & $-15,1$ & $-11,0$ & $-11,2$ & $-9,7$ \\
SC & 1,9 & 8,0 & 4,6 & 3,6 & 3,1 & 3,7 & 6,2 & 5,9 & 6,5 & 4,8 \\
SP & 11,5 & 2,5 & 8,8 & 11,7 & 13,2 & 11,3 & 8,6 & 9,1 & 8,7 & 9,7 \\
MG & $-1,6$ & -10 & $-1,2$ & $-4,3$ & $-4,5$ & $-2,5$ & $-5,1$ & $-5,6$ & $-4,5$ & $-4,2$ \\
RJ & 2,9 & 2,8 & 1,4 & 2,3 & 2,3 & 2,3 & 2,3 & 2,2 & 2,0 & 2,3 \\
ES & 0,5 & $-0,4$ & 0,5 & 0,2 & 0,4 & 1,0 & 0,7 & 0,7 & 0,9 & 0,5 \\
\hline
\end{tabular}

Fonte: Estimativa do autor.

Helfand \& Rezende (1998) estimaram o consumo de milho para todos os estados do Brasil e obtiveram resultados semelhantes aos aqui apresentados. De acordo com esses autores existe grande excedente no Paraná e déficit em São Paulo e Santa Catarina. No período de 1990 a 1995, São Paulo produziu 12,6\% do milho do país, no entanto, respondeu por $16,8 \%$ do consumo. O Paraná exportou quase $9 \%$ da produção doméstica nos anos 90 .

As figuras 28 a 32 ilustram o balanço entre produção e consumo de milho nos estados das regiões Sul e Sudeste em 1997/1998 mês a mês ${ }^{20}$. Esse balanço foi calculado deduzindose o consumo da produção estadual. Não foi possível considerar os estoques de passagem por falta de dados sobre armazenagem. Assim, a estimativa do balanço não considerou o estoque final e inicial. Nos meses em que houve excedente foi o mesmo acumulado no mês seguinte. No caso de posições de escassez, supõe-se que a mesma foi atendida pela produção de outro estado. Em outras palavras, o consumo nas regiões estudadas foi sempre atendido, quem seja pela produção ou pelo fluxo de comércio.

Percebe-se que São Paulo é o estado que apresenta maior déficit ao longo do ano, seguido por Santa Catarina. Os demais estados não apresentaram problemas. Porém, o consumo do milho nesses estados é maior do que o estimado no presente trabalho, pois existe parcela do milho produzido que é consumida na propriedade rural. Assim, o déficit de alguns estados, como São Paulo e Santa Catarina, pode ser, na realidade, maior que o ilustrado e os excedentes, verificados nos demais estados, menores.

\footnotetext{
${ }^{20}$ Outros anos do período 1990-1998 são apresentados no Anexo B.
} 
O Censo Agropecuário 1995-1996 estimou o quanto da produção de milho é consumida no estabelecimento em cada estado. Os resultados são os seguintes: Rio Grande do Sul, 49\%; Minas Gerais, 39\%; São Paulo, 19\% e Paraná, 14\%.

Não seria correto considerar esses percentuais como sendo o autoconsumo, pois uma parcela do consumo estaria sendo contabilizada duas vezes devido aos produtores que, apesar de cultivarem milho, utilizam o mesmo na alimentação dos animais que serão comercializados. Ou seja, o produto final é destinado ao comércio e não à subsistência. Esse consumo está quantificado no trabalho.

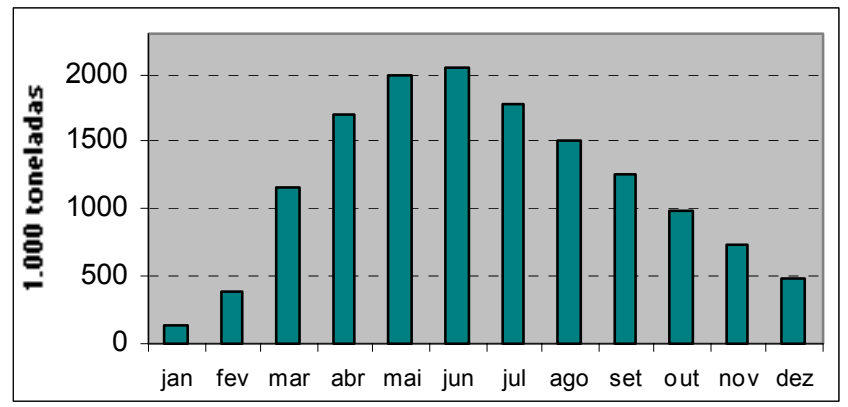

Figura 28 - Balanço de suprimento do milho no estado do Rio Grande do Sul, 1997

Fonte: Estimativa do autor.

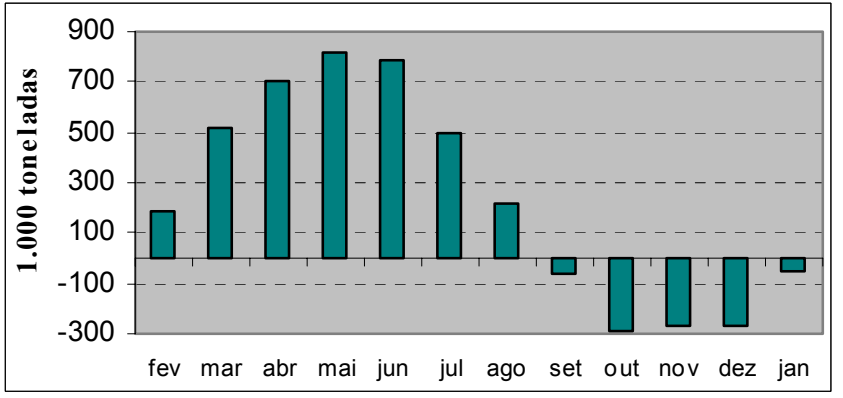

Figura 29 - Balanço de suprimento do milho no estado de Santa Catarina, 1997

Fonte: Estimativa do autor. 


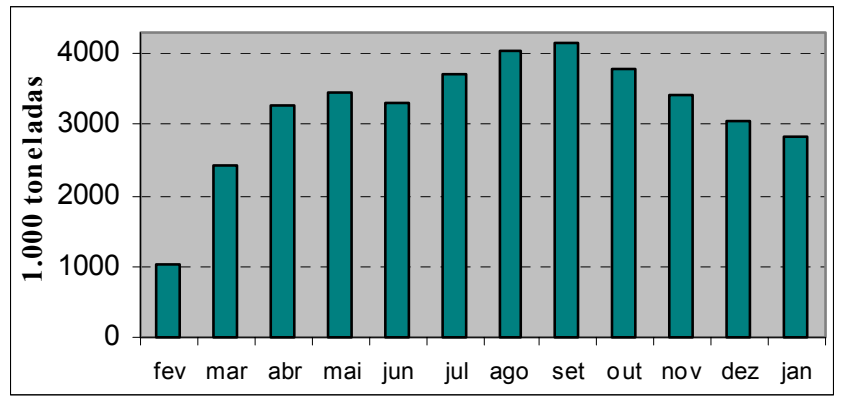

Figura 30 - Balanço de suprimento do milho no estado do Paraná, 1997

Fonte: Estimativa do autor.

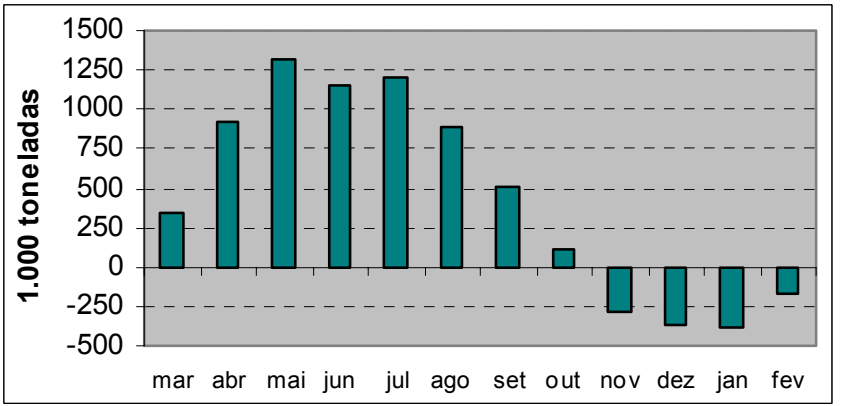

Figura 31 - Balanço de suprimento do milho no estado de São Paulo, 1997

Fonte: Estimativa do autor. 


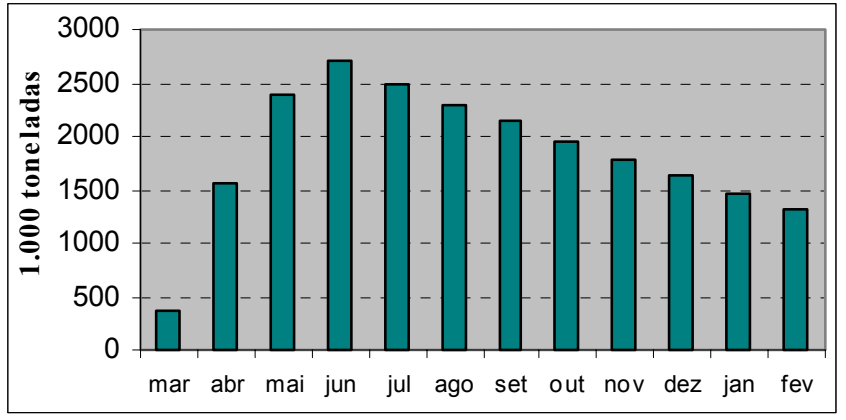

Figura 32 - Balanço de suprimento do milho no estado de Minas Gerais, 1997

Fonte: Estimativa do autor.

Para ilustrar o impacto do autoconsumo nos resultados do presente trabalho, utilizou-se a pressuposição de que 30 a $50 \%$ do consumo no estabelecimento identificado pelo Censo Agropecuário 1995-96 é de subsistência. Assim sendo, as seguintes conclusões podem ser obtidas: no período de outubro a dezembro o estado do Rio Grande do Sul também não supre o seu consumo de milho. Em Santa Catarina o déficit que começava a aparecer apenas no mês de setembro, seria de 284 mil toneladas em agosto quando considerado $30 \%$ do consumo no estabelecimento estimado pelo Censo ou déficit de 30 mil toneladas já no mês de julho no caso dos 50\%. Em São Paulo a escassez de 279 mil toneladas em novembro estaria situado entre 106 a 246 mil toneladas já no mês de outubro. Os demais estados continuaram apresentando excedente ao longo do ano.

\subsection{Variação Estacional do Preço do Milho}

As figuras 33 a 37 apresentam o índice sazonal e o limite inferior e superior do preço do milho no Rio Grande do Sul, Santa Catarina, Paraná, São Paulo e Minas Gerais.

No Rio Grande do Sul normalmente o preço do milho atinge seu mínimo nos meses de março e abril, como revela a figura 33. Isso se deve ao fato do pico da colheita ocorrer principalmente nesses meses, ou seja, $28 \%$ da safra são colhidos no mês de março e $23 \%$ em abril. Os dados do ritmo de colheita podem ser vistos no Anexo C. 


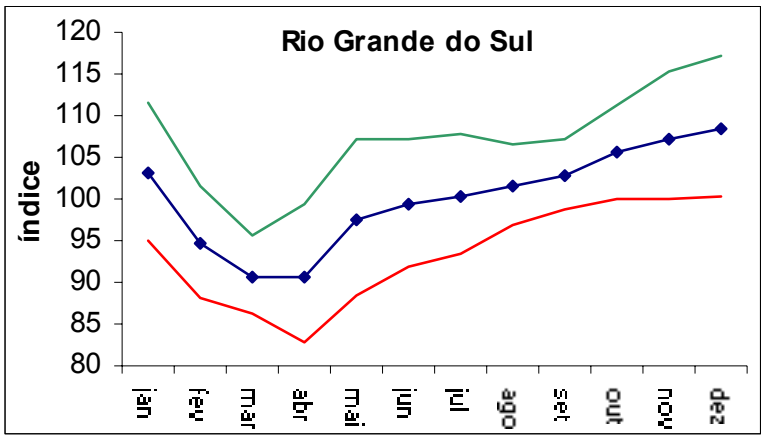

Figura 33 - Índices sazonais e seus limites Superior e Inferior, obtidos a partir do método de média geométrica para o estado do Rio Grande do Sul, 1990 - 1998.

Fonte: Estimativa do autor.

A colheita em Santa Catarina ocorre no período de janeiro a junho e os déficits mostrados no capítulo anterior começam no mês de setembro e acabam em fevereiro. Esses dois fatores explicam o aumento dos índices sazonais de setembro a dezembro e em janeiro.

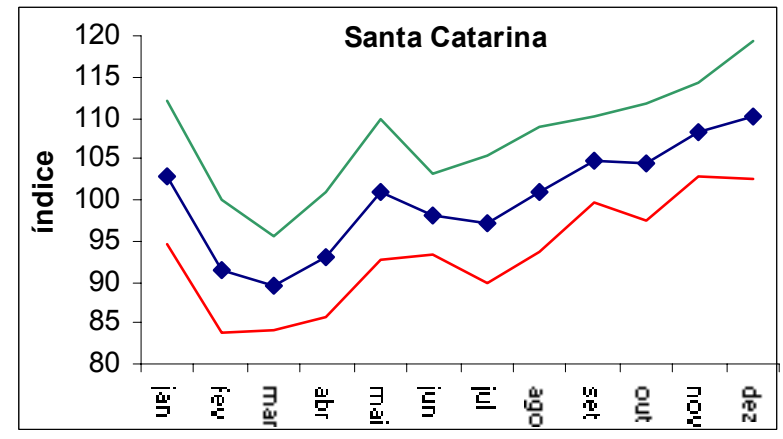

Figura 34 - Índices sazonais e seus limites Superior e Inferior, obtidos a partir do método de média geométrica para o estado do Santa Catarina, 1990 - 1998

Fonte: Estimativa do autor.

No estado do Paraná, os menores índices sazonais ocorrem no período de janeiro a agosto, devido a colheita começar em janeiro e terminar somente em setembro. O Paraná é o maior produtor da segunda safra de milho (safrinha), o que justifica a colheita se estender até 
setembro. Além disso, o pico da safra ocorre em março, quando o índice sazonal alcança seu valor mínimo $(92,46)$. Ver figura 35.

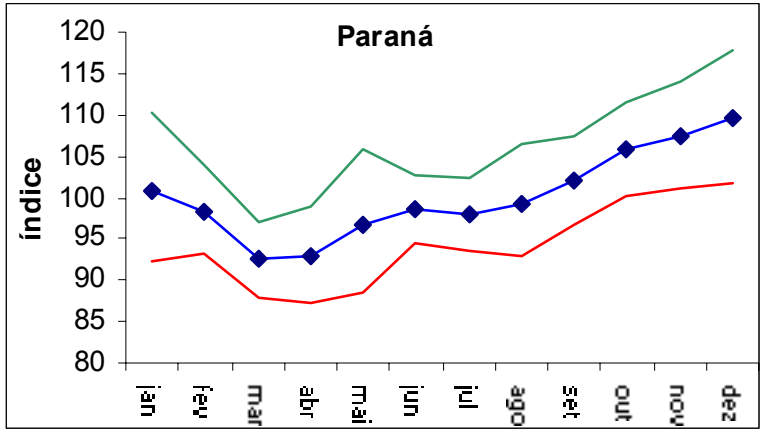

Figura 35 - Índices sazonais e seus limites Superior e Inferior, obtidos a partir do método de média geométrica para o estado do Paraná, 1990 - 1998

Fonte: Estimativa do autor.

Não há colheita no estado de São Paulo no mês de janeiro e no período de setembro a dezembro. Os maiores déficits nesse estado ocorrem entre novembro e janeiro. É por isso que, nesses meses, o preço atinge o seu máximo (figura 36).

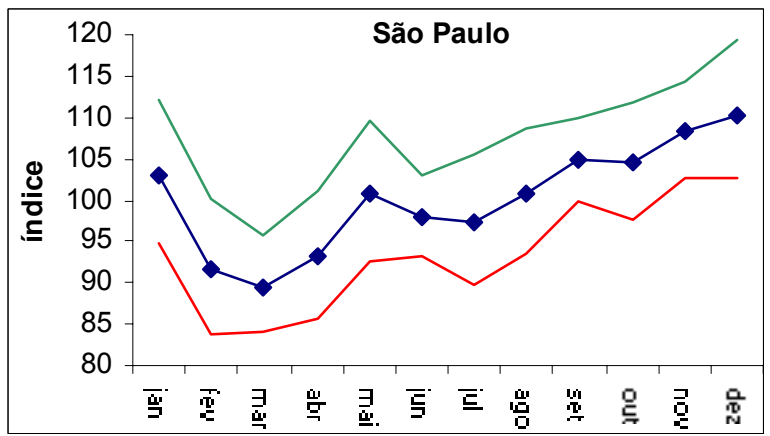

Figura 36 - Índices sazonais e seus limites Superior e Inferior, obtidos a partir do método de média geométrica para o estado de São Paulo, 1990 - 1998

Fonte: Estimativa do autor. 
O preço em Minas Gerais (figura 37) se mantém em patamares baixos por um período de seis meses (março a agosto). Foi o estado que apresentou o menor índice sazonal $(86,96)$, possivelmente por não haver escassez de milho ao longo do ano .

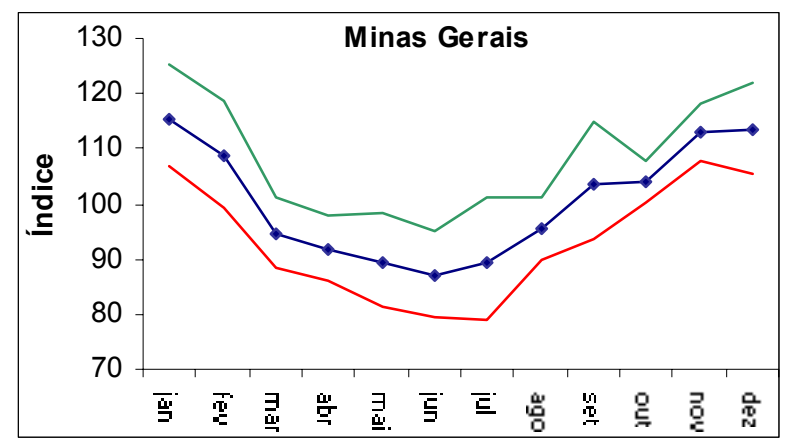

Figura 37 - Índices sazonais e seus limites Superior e Inferior, obtidos a partir do método de média geométrica para o estado de Minas Gerais, 1990 - 1998

Fonte: Estimativa do autor.

No anexo D, o exame mais detalhado dos índices estacionais indica que, em todos os estados, com exceção do Paraná e Santa Catarina, houve modificações no padrão da variação estacional do preço do milho, no sentido de diminuir a amplitude dessa variação a partir de 1994-95. 


\section{CONCLUSÕES}

Entender o mercado de milho é tarefa árdua para qualquer agente econômico que trabalhe com o produto. A proposta inicial deste estudo foi justamente esboçar uma fotografia do mercado para que, a partir desta, novos estudos pudessem aprofundar o conhecimento das relações que regem a evolução de preços do milho e os fluxos de produção e consumo no Sul e Sudeste do Brasil.

Desde logo, vale destacar a carência de estudos, conhecimento técnico e de dados estatísticos que ajudem essa empreitada. Poucos trabalhos procuraram caracterizar os agentes econômicos que participam desse mercado e as relações entre eles.

A principal contribuição deste estudo, além dos resultados apresentados, foi a construção e teste de uma metodologia que possa viabilizar essas informações, ponto de partida para qualquer estudo futuro do mercado. A leitura dos resultados aqui apresentados deve, portanto, ser feita sob a ótica de quem buscou desenvolver e aprimorar uma metodologia que eventualmente está distante do ideal.

Não é surpresa, por esse motivo, que alguns resultados sejam contraditórios ou diferentes do esperado. Sobretudo, no caso de relações entre oferta e preços do produto.

Ponto a ser destacado e discutido na literatura refere-se ao processo de difusão da tecnologia na explicação da conformação do mercado. A dualidade tecnológica existente nessa lavoura parece ser inerente aos mecanismos de difusão de tecnologia que prevalecem no caso do milho.

Outra questão importante refere-se aos fluxos interestaduais de milho que, uma vez identificados, poderão ajudar a entender a dinâmica do mercado e dos preços. Tais fluxos poderão ser melhor entendidos comparando-se o balanço de suprimento de milho nos 
diferentes estados do Sul e Sudeste com os índices sazonais de preços estimados para os estados dessas regiões.

Os estados com excedente de milho devem ser exportadores líquidos do produto e responsáveis pelo atendimento de mercados deficitários. O esperado seria que os meses cujos resultados líquidos apresentam-se pequenos ou mesmo negativos serem os de preços mais elevados. De fato, na maioria das vezes isto ocorre, mas existem exceções que devem ser analisadas e explicadas em futura pesquisa.

O consumo de milho estimado captou o momento exato do consumo nos diferentes segmentos, com exceção de outros animais e pecuária de leite. Ou seja, o suprimento do milho não foi calculado no momento de sua compra. Por exemplo, o produtor de frango estoca o milho 20 ou 30 dias antes de consumi-lo.

O consumidor de milho espera que o preço diminua nas épocas da colheita. Assim, deixa de comprá-lo, diminui seu estoque e aguarda a queda do preço. A procura do produto diminui e, consequentemente, o preço poderá cair antes do previsto.

Apesar de não serem disponíveis estatísticas sobre o fluxo de comércio interestadual, os índices de variação estacional calculados para Santa Catarina e Paraná sugerem que as transações entre esses estados afetam de modo significativo o preço do milho. A título de exemplo, nos meses de setembro a janeiro, quando há escassez em Santa Catarina e excedente no Paraná, os índices sazonais de preço de milho evoluem de modo muito semelhante.

Nos anos em que ocorre quebra da safrinha (maio a setembro), muitas vezes o produtor acredita que irá faltar milho no período de novembro a dezembro e estoca o produto na expectativa de preço mais alto. Porém, quando se aproxima a colheita e se grande parte do milho está armazenada e não vendida, o produtor antecipando provável queda de preço, começa a ofertar o produto. Assim, o preço poderá diminuir antes da época normalmente previsível.

O consumo na propriedade rural deve exercer grande influência no preço do milho. Quando o preço está alto, os produtores que produzem apenas para subsistência poderão vender excedentes. Se isso de fato ocorrer em larga escala, a quantidade ofertada aumentará e, em determinados momentos, o preço não atingirá os níveis previstos. 
Abertura da economia, uso da irrigação e aumento da produção de milho na entre-safra (safrinha) são fatores que provavelmente influenciaram a alteração da volatilidade dos preços nos anos 90. Esses fatores teriam possibilitado aumento da quantidade ofertada do produto em épocas de escassez e atenuado as oscilações de preço.

Por fim, a metodologia desenvolvida nesta dissertação poderá contribuir como base para estudos de abrangência nacional. Depois de medido o consumo no Brasil, quantificar o autoconsumo será uma importante contribuição para o entendimento das relações econômicas vigentes no mercado de milho. 
ANEXOS 


\section{ANEXO A - Consumo de milho nas regiões Sul e Sudeste do Brasil, 1990- 1998.}

A1: Consumo de milho nas regiões Sul e Sudeste do Brasil, 1990-1998 (em mil toneladas).

\begin{tabular}{lrrrrrrrrr}
\hline & 1990 & 1991 & 1992 & 1993 & 1994 & 1995 & 1996 & 1997 & 1998 \\
\hline & & & & & & & & & \\
Sul & 6.884 & 7.345 & 8.462 & 8.341 & 9.033 & 9.767 & 10.354 & 10.851 & 11.202 \\
RS & 1.751 & 1.929 & 2.211 & 2.274 & 2.510 & 2.816 & 3.001 & 3.145 & 3.331 \\
PR & 2.966 & 3.151 & 3.559 & 3.561 & 3.816 & 4.002 & 4.232 & 4.337 & 4.445 \\
SC & 2.168 & 2.265 & 2.692 & 2.506 & 2.707 & 2.949 & 3.121 & 3.370 & 3.426 \\
Sudeste & 5.439 & 5.835 & 6.424 & 6.236 & 6.557 & 7.198 & 7.279 & 7.799 & 7.739 \\
SP & 3.417 & 3.577 & 3.805 & 3.963 & 4.188 & 4.582 & 4.604 & 4.924 & 4.752 \\
MG & 1.447 & 1.643 & 2.134 & 1.693 & 1.753 & 1.957 & 1.997 & 2.175 & 2.305 \\
RJ & 376 & 412 & 248 & 371 & 401 & 415 & 432 & 438 & 411 \\
ES & 199 & 202 & 237 & 209 & 215 & 243 & 247 & 262 & 271 \\
Total & 12.323 & 13.180 & 14.885 & 14.577 & 15.590 & 16.965 & 17.633 & 18.651 & 18.941 \\
\hline
\end{tabular}

Fonte: Estimativa do autor.

A2. Consumo de milho na avicultura de corte nas regiões Sul e Sudeste do Brasil, 1990-1998 (em mil toneladas).

\begin{tabular}{lrrrrrrrrr}
\hline & 1990 & 1991 & 1992 & 1993 & 1994 & 1995 & 1996 & 1997 & 1998 \\
\hline & & & & & & & & & \\
Sul & 2.729 & 2.891 & 3.637 & 3.427 & 3.751 & 4.044 & 4.412 & 4.712 & 4.792 \\
RS & 748 & 811 & 995 & 1.041 & 1.168 & 1.322 & 1.424 & 1.509 & 1.513 \\
PR & 877 & 933 & 1.172 & 1.114 & 1.201 & 1.275 & 1.451 & 1.505 & 1.615 \\
SC & 1.103 & 1.147 & 1.471 & 1.273 & 1.382 & 1.448 & 1.537 & 1.699 & 1.664 \\
Sudeste & 1.844 & 2.095 & 2.394 & 2.279 & 2.421 & 2.680 & 2.575 & 2.873 & 2.793 \\
SP & 1.150 & 1.289 & 1.337 & 1.465 & 1.570 & 1.731 & 1.648 & 1.850 & 1.724 \\
MG & 434 & 514 & 889 & 552 & 558 & 641 & 612 & 724 & 785 \\
RJ & 197 & 221 & 71 & 185 & 211 & 214 & 216 & 195 & 176 \\
ES & 64 & 70 & 97 & 76 & 82 & 94 & 100 & 104 & 109 \\
Total & 4.573 & 4.987 & 6.031 & 5.706 & 6.172 & 6.725 & 6.987 & 7.585 & 7.585 \\
\hline
\end{tabular}

Fonte: Estimativa do autor. 
A3. Consumo de milho na avicultura de postura nas regiões Sul e Sudeste do Brasil, 1990-1998 (em mil toneladas).

\begin{tabular}{lrrrrrrrrr}
\hline & 1990 & 1991 & 1992 & 1993 & 1994 & 1995 & 1996 & 1997 & 1998 \\
\hline & & & & & & & & & \\
Sul & 226 & 254 & 285 & 267 & 284 & 343 & 335 & 246 & 259 \\
RS & 70 & 98 & 116 & 107 & 104 & 131 & 129 & 89 & 97 \\
PR & 128 & 127 & 135 & 127 & 148 & 175 & 166 & 124 & 126 \\
SC & 28 & 30 & 34 & 34 & 32 & 37 & 40 & 33 & 36 \\
Sudeste & 774 & 777 & 774 & 693 & 703 & 820 & 817 & 701 & 758 \\
SP & 560 & 561 & 562 & 514 & 534 & 621 & 620 & 535 & 575 \\
MG & 152 & 153 & 145 & 124 & 118 & 133 & 134 & 114 & 129 \\
RJ & 27 & 30 & 31 & 23 & 20 & 23 & 22 & 14 & 12 \\
ES & 35 & 33 & 35 & 32 & 31 & 43 & 40 & 38 & 43 \\
Total & 1.000 & 1.032 & 1.059 & 960 & 987 & 1.162 & 1.152 & 946 & 1.017 \\
\hline & & & & & & & & &
\end{tabular}

Fonte: Estimativa do autor.

A4. Consumo de milho na suinocultura nas regiões Sul e Sudeste do Brasil, 1990-1998 (em mil toneladas).

\begin{tabular}{lrrrrrrrrr}
\hline & 1990 & 1991 & 1992 & 1993 & 1994 & 1995 & 1996 & 1997 & 1998 \\
\hline & & & & & & & & & \\
Sul & 2.074 & 2.244 & 2.406 & 2.441 & 2.694 & 2.974 & 3.122 & 3.291 & 3.567 \\
RS & 567 & 627 & 666 & 672 & 744 & 825 & 874 & 918 & 1.088 \\
PR & 615 & 676 & 721 & 727 & 825 & 868 & 896 & 933 & 954 \\
SC & 892 & 940 & 1.019 & 1.042 & 1.125 & 1.282 & 1.352 & 1.439 & 1.526 \\
Sudeste & 485 & 530 & 549 & 545 & 585 & 675 & 713 & 720 & 790 \\
SP & 215 & 239 & 253 & 252 & 276 & 323 & 338 & 339 & 346 \\
MG & 192 & 214 & 227 & 226 & 247 & 288 & 314 & 317 & 381 \\
RJ & 33 & 33 & 28 & 27 & 24 & 25 & 25 & 26 & 26 \\
ES & 44 & 43 & 40 & 40 & 38 & 38 & 35 & 37 & 37 \\
Total & 2.559 & 2.773 & 2.955 & 2.985 & 3.279 & 3.649 & 3.834 & 4.011 & 4.358 \\
\hline
\end{tabular}

Fonte: Estimativa do autor. 
A5. Consumo de milho na pecuária de leite nas regiões Sul e Sudeste do Brasil, 1990-1998 (em mil toneladas).

\begin{tabular}{lrrrrrrrrr}
\hline & 1990 & 1991 & 1992 & 1993 & 1994 & 1995 & 1996 & 1997 & 1998 \\
\hline & & & & & & & & & \\
Sul & 370 & 399 & 464 & 458 & 506 & 559 & 605 & 626 & 646 \\
RS & 173 & 191 & 221 & 227 & 251 & 284 & 307 & 328 & 338 \\
PR & 107 & 115 & 134 & 130 & 145 & 155 & 169 & 169 & 174 \\
SC & 89 & 93 & 109 & 101 & 111 & 119 & 129 & 130 & 134 \\
Sudeste & 460 & 450 & 617 & 530 & 559 & 635 & 646 & 688 & 705 \\
SP & 148 & 92 & 166 & 173 & 186 & 212 & 215 & 227 & 233 \\
MG & 264 & 308 & 414 & 310 & 323 & 370 & 376 & 404 & 413 \\
RJ & 30 & 34 & 17 & 29 & 32 & 33 & 34 & 35 & 35 \\
ES & 17 & 17 & 20 & 17 & 18 & 21 & 21 & 23 & 23 \\
Total & 829 & 850 & 1.081 & 988 & 1.065 & 1.194 & 1.251 & 1.315 & 1.350 \\
\hline
\end{tabular}

Fonte: Estimativa do autor.

A6. Consumo de milho na pecuária de corte nas regiões Sul e Sudeste do Brasil, 1990-1998 (em mil toneladas).

\begin{tabular}{lrrrrrrrrr}
\hline & 1990 & 1991 & 1992 & 1993 & 1994 & 1995 & 1996 & 1997 & 1998 \\
\hline & & & & & & & & & \\
Sul & 77 & 70 & 74 & 75 & 90 & 114 & 131 & 140 & 130 \\
RS & 24 & 22 & 22 & 23 & 27 & 33 & 37 & 41 & 47 \\
PR & 37 & 35 & 38 & 42 & 50 & 65 & 75 & 80 & 61 \\
SC & 16 & 13 & 13 & 11 & 13 & 16 & 19 & 19 & 22 \\
Sudeste & 193 & 216 & 210 & 207 & 247 & 298 & 357 & 407 & 333 \\
SP & 113 & 116 & 119 & 123 & 148 & 190 & 241 & 283 & 219 \\
MG & 57 & 81 & 67 & 65 & 80 & 85 & 93 & 101 & 90 \\
RJ & 13 & 11 & 13 & 11 & 11 & 14 & 14 & 14 & 15 \\
ES & 11 & 8 & 11 & 8 & 8 & 8 & 9 & 9 & 9 \\
Total & 270 & 286 & 283 & 282 & 338 & 412 & 488 & 547 & 463 \\
\hline
\end{tabular}

Fonte: Estimativa do autor. 
A7. Consumo de milho em outros animais nas regiões Sul e Sudeste do Brasil, 1990-1998 (em mil toneladas).

\begin{tabular}{lrrrrrrrrr}
\hline & 1990 & 1991 & 1992 & 1993 & 1994 & 1995 & 1996 & 1997 & 1998 \\
\hline & & & & & & & & & \\
Sul & 63 & 77 & 77 & 92 & 109 & 118 & 153 & 239 & 222 \\
RS & 24 & 30 & 30 & 35 & 42 & 45 & 59 & 92 & 85 \\
PR & 35 & 43 & 43 & 51 & 60 & 66 & 85 & 133 & 123 \\
SC & 4 & 5 & 5 & 6 & 7 & 7 & 10 & 15 & 14 \\
Sudeste & 173 & 212 & 211 & 252 & 298 & 324 & 420 & 655 & 609 \\
SP & 106 & 130 & 129 & 154 & 182 & 198 & 256 & 400 & 372 \\
MG & 36 & 44 & 44 & 52 & 61 & 67 & 86 & 135 & 126 \\
RJ & 25 & 30 & 30 & 36 & 43 & 46 & 60 & 93 & 87 \\
ES & 7 & 9 & 8 & 10 & 12 & 13 & 17 & 26 & 24 \\
Total & 236 & 290 & 288 & 344 & 407 & 443 & 573 & 894 & 831 \\
\hline
\end{tabular}

Fonte: Estimativa do autor.

A8. Consumo de milho na indústria nas regiões Sul e Sudeste do Brasil, 1990-1998 (em mil toneladas).

\begin{tabular}{lrrrrrrrrr}
\hline & 1990 & 1991 & 1992 & 1993 & 1994 & 1995 & 1996 & 1997 & 1998 \\
\hline & & & & & & & & & \\
Sul & 1.286 & 1.341 & 1.452 & 1.505 & 1.525 & 1.525 & 1.525 & 1.525 & 1.525 \\
RS & 127 & 132 & 143 & 148 & 150 & 150 & 150 & 150 & 150 \\
PR & 1.139 & 1.187 & 1.285 & 1.332 & 1.350 & 1.350 & 1.350 & 1.350 & 1.350 \\
SC & 21 & 22 & 24 & 25 & 25 & 25 & 25 & 25 & 25 \\
Sudeste & 1.396 & 1.456 & 1.575 & 1.633 & 1.655 & 1.655 & 1.655 & 1.655 & 1.655 \\
SP & 1.054 & 1.099 & 1.190 & 1.233 & 1.250 & 1.250 & 1.250 & 1.250 & 1.250 \\
MG & 270 & 281 & 305 & 316 & 320 & 320 & 320 & 320 & 320 \\
RJ & 51 & 53 & 57 & 59 & 60 & 60 & 60 & 60 & 60 \\
ES & 21 & 22 & 24 & 25 & 25 & 25 & 25 & 25 & 25 \\
Total & 2.682 & 2.797 & 3.027 & 3.138 & 3.180 & 3.180 & 3.180 & 3.180 & 3.180 \\
\hline
\end{tabular}

Fonte: Estimativa do autor. 
A9. Perdas de milho no armazenamento e transporte, 1990-1998 (em mil toneladas).

\begin{tabular}{lrrrrrrrrr}
\hline & 1990 & 1991 & 1992 & 1993 & 1994 & 1995 & 1996 & 1997 & 1998 \\
\hline & & & & & & & & & \\
Sul & 1.159 & 781 & 1.571 & 1.529 & 1.556 & 1.793 & 1.218 & 1.384 & 1.403 \\
RS & 459 & 237 & 642 & 534 & 551 & 689 & 344 & 475 & 516 \\
PR & 397 & 372 & 561 & 629 & 629 & 692 & 611 & 597 & 595 \\
SC & 302 & 172 & 368 & 366 & 376 & 413 & 264 & 311 & 292 \\
Sudeste & 383 & 607 & 608 & 597 & 555 & 592 & 523 & 602 & 566 \\
SP & 127 & 186 & 187 & 169 & 147 & 191 & 162 & 179 & 167 \\
MG & 234 & 382 & 388 & 391 & 379 & 386 & 343 & 403 & 382 \\
RJ & 3 & 5 & 6 & 6 & 6 & 3 & 4 & 4 & 4 \\
ES & 19 & 33 & 28 & 30 & 23 & 12 & 14 & 16 & 13 \\
Total & 1.542 & 1.388 & 2.179 & 2.126 & 2.111 & 2.386 & 1.742 & 1.986 & 1.970 \\
\hline
\end{tabular}

Fonte: Estimativa do autor.

A10. Consumo mensal de milho nas regiões Sul e Sudeste do Brasil, 1990 (em mil toneladas).

\begin{tabular}{|c|c|c|c|c|c|c|c|c|c|c|c|c|c|}
\hline & Jan & Fev & Mar & $\mathrm{Abr}$ & Mai & Jun & Jul & Ago & Set & Out & Nov & Dez & Total \\
\hline Sul & 552 & 538 & 549 & 618 & 615 & 580 & 586 & 578 & 574 & 582 & 566 & 547 & 6.884 \\
\hline RS & 140 & 142 & 139 & 160 & 146 & 146 & 152 & 148 & 145 & 149 & 147 & 138 & 1.751 \\
\hline PR & 241 & 235 & 241 & 254 & 258 & 255 & 251 & 244 & 248 & 254 & 248 & 238 & 2.966 \\
\hline SC & 172 & 161 & 169 & 204 & 211 & 180 & 184 & 186 & 180 & 179 & 171 & 172 & 2.168 \\
\hline Sudeste & 413 & 398 & 429 & 436 & 489 & 483 & 504 & 512 & 454 & 464 & 447 & 410 & 5.439 \\
\hline $\mathrm{SP}$ & 266 & 258 & 276 & 276 & 304 & 297 & 310 & 313 & 283 & 287 & 284 & 262 & 3.417 \\
\hline MG & 106 & 99 & 110 & 115 & 134 & 135 & 142 & 145 & 123 & 125 & 117 & 95 & 1.447 \\
\hline RJ & 27 & 27 & 28 & 29 & 33 & 32 & 33 & 35 & 31 & 35 & 30 & 36 & 376 \\
\hline ES & 15 & 14 & 15 & 15 & 18 & 18 & 19 & 19 & 17 & 16 & 15 & 18 & 199 \\
\hline Total & 965 & 935 & 978 & 1.054 & 1.104 & 1.063 & 1.090 & 1.089 & 1.028 & 1.046 & 1.013 & 958 & 12.323 \\
\hline
\end{tabular}

Fonte: Estimativa do autor. 
A11. Consumo mensal de milho nas regiões Sul e Sudeste do Brasil, 1991 (em mil toneladas).

\begin{tabular}{|c|c|c|c|c|c|c|c|c|c|c|c|c|c|}
\hline & Jan & Fev & Mar & Abr & Mai & Jun & Jul & Ago & Set & Out & Nov & Dez & Total \\
\hline Sul & 706 & 662 & 690 & 772 & 791 & 743 & 752 & 765 & 757 & 778 & 749 & 731 & 7.345 \\
\hline RS & 209 & 201 & 202 & 225 & 218 & 217 & 224 & 228 & 221 & 229 & 224 & 211 & 1.929 \\
\hline PR & 224 & 216 & 226 & 243 & 256 & 251 & 245 & 245 & 248 & 255 & 248 & 238 & 3.151 \\
\hline SC & 273 & 246 & 262 & 304 & 316 & 275 & 283 & 292 & 287 & 293 & 276 & 282 & 2.265 \\
\hline Sudeste & 466 & 443 & 487 & 498 & 586 & 577 & 612 & 653 & 536 & 549 & 556 & 510 & 5.835 \\
\hline $\mathrm{SP}$ & 273 & 265 & 292 & 294 & 341 & 335 & 356 & 378 & 297 & 299 & 330 & 307 & 3.577 \\
\hline MG & 130 & 122 & 136 & 143 & 174 & 172 & 185 & 198 & 167 & 170 & 155 & 124 & 1.643 \\
\hline RJ & 44 & 38 & 40 & 41 & 49 & 48 & 49 & 54 & 52 & 58 & 50 & 56 & 412 \\
\hline ES & 18 & 18 & 19 & 19 & 22 & 22 & 22 & 24 & 21 & 22 & 22 & 23 & 202 \\
\hline Total & 1.172 & 1.106 & 1.177 & 1.270 & 1.377 & 1.320 & 1.364 & 1.418 & 1.293 & 1.327 & 1.306 & 1.240 & 13.180 \\
\hline
\end{tabular}

Fonte: Estimativa do autor.

A12. Consumo mensal de milho nas regiões Sul e Sudeste do Brasil, 1992 (em mil toneladas).

\begin{tabular}{|c|c|c|c|c|c|c|c|c|c|c|c|c|c|}
\hline & Jan & Fev & Mar & Abr & Mai & Jun & Jul & Ago & Set & Out & Nov & Dez & Total \\
\hline Sul & 643 & 660 & 672 & 750 & 747 & 710 & 728 & 717 & 721 & 732 & 698 & 683 & 8.462 \\
\hline RS & 170 & 179 & 174 & 200 & 185 & 187 & 195 & 191 & 187 & 190 & 182 & 171 & 2.211 \\
\hline PR & 274 & 284 & 291 & 302 & 304 & 304 & 303 & 297 & 305 & 308 & 296 & 291 & 3.559 \\
\hline SC & 199 & 196 & 207 & 248 & 258 & 220 & 230 & 229 & 229 & 235 & 220 & 221 & 2.692 \\
\hline Sudeste & 495 & 495 & 519 & 518 & 581 & 570 & 595 & 602 & 533 & 539 & 503 & 474 & 6.424 \\
\hline $\mathrm{SP}$ & 309 & 298 & 309 & 306 & 341 & 332 & 343 & 347 & 312 & 314 & 301 & 291 & 3.805 \\
\hline MG & 139 & 161 & 172 & 175 & 196 & 195 & 207 & 211 & 184 & 183 & 168 & 143 & 2.134 \\
\hline RJ & 29 & 18 & 19 & 18 & 21 & 21 & 22 & 21 & 18 & 24 & 17 & 19 & 248 \\
\hline ES & 17 & 18 & 19 & 19 & 22 & 21 & 22 & 22 & 19 & 19 & 17 & 21 & 237 \\
\hline Total & 1.138 & 1.155 & 1.191 & 1.268 & 1.327 & 1.280 & 1.323 & 1.319 & 1.254 & 1.271 & 1.201 & 1.157 & 14.885 \\
\hline
\end{tabular}

Fonte: Estimativa do autor. 
A13. Consumo mensal de milho nas regiões Sul e Sudeste do Brasil, 1993 (em mil toneladas).

\begin{tabular}{|c|c|c|c|c|c|c|c|c|c|c|c|c|c|}
\hline & Jan & Fev & Mar & Abr & Mai & Jun & Jul & Ago & Set & Out & Nov & Dez & Total \\
\hline Sul & 691 & 642 & 664 & 738 & 733 & 695 & 703 & 696 & 697 & 711 & 692 & 681 & 8.341 \\
\hline RS & 184 & 184 & 182 & 208 & 190 & 188 & 194 & 192 & 188 & 194 & 191 & 180 & 2.274 \\
\hline PR & 294 & 275 & 287 & 302 & 305 & 305 & 301 & 294 & 301 & 306 & 299 & 293 & 3.561 \\
\hline SC & 213 & 184 & 195 & 229 & 238 & 202 & 208 & 210 & 208 & 211 & 202 & 208 & 2.506 \\
\hline Sudeste & 518 & 458 & 496 & 505 & 565 & 549 & 567 & 576 & 511 & 525 & 498 & 468 & 6.236 \\
\hline $\mathrm{SP}$ & 320 & 302 & 324 & 326 & 355 & 342 & 352 & 357 & 323 & 331 & 324 & 307 & 3.963 \\
\hline MG & 159 & 115 & 129 & 135 & 158 & 156 & 162 & 166 & 141 & 139 & 128 & 105 & 1.693 \\
\hline RJ & 22 & 26 & 26 & 27 & 32 & 33 & 34 & 34 & 31 & 39 & 31 & 36 & 371 \\
\hline ES & 17 & 15 & 17 & 17 & 19 & 18 & 19 & 19 & 17 & 17 & 16 & 19 & 209 \\
\hline Total & 1.208 & 1.101 & 1.159 & 1.244 & 1.297 & 1.244 & 1.270 & 1.272 & 1.208 & 1.236 & 1.190 & 1.148 & 14.577 \\
\hline
\end{tabular}

Fonte: Estimativa do autor.

A14. Consumo mensal de milho nas regiões Sul e Sudeste do Brasil, 1994 (em mil toneladas).

\begin{tabular}{|c|c|c|c|c|c|c|c|c|c|c|c|c|c|}
\hline & Jan & Fev & Mar & Abr & Mai & Jun & Jul & Ago & Set & Out & Nov & Dez & Total \\
\hline Sul & 712 & 686 & 711 & 801 & 801 & 754 & 764 & 762 & 762 & 774 & 756 & 748 & 9.033 \\
\hline RS & 196 & 197 & 196 & 225 & 208 & 205 & 215 & 217 & 212 & 218 & 216 & 205 & 2.510 \\
\hline PR & 305 & 297 & 309 & 325 & 331 & 326 & 323 & 317 & 325 & 327 & 318 & 312 & 3.816 \\
\hline SC & 211 & 192 & 206 & 252 & 263 & 223 & 226 & 228 & 225 & 229 & 222 & 231 & 2.707 \\
\hline Sudeste & 503 & 472 & 507 & 516 & 595 & 587 & 609 & 620 & 543 & 555 & 535 & 514 & 6.557 \\
\hline $\mathrm{SP}$ & 329 & 309 & 329 & 330 & 376 & 371 & 381 & 386 & 345 & 348 & 347 & 338 & 4.188 \\
\hline MG & 126 & 120 & 132 & 137 & 166 & 165 & 174 & 178 & 149 & 150 & 140 & 117 & 1.753 \\
\hline RJ & 31 & 29 & 31 & 32 & 34 & 32 & 34 & 36 & 33 & 40 & 31 & 38 & 401 \\
\hline ES & 17 & 15 & 16 & 17 & 19 & 19 & 20 & 20 & 17 & 17 & 17 & 21 & 215 \\
\hline Total & 1.215 & 1.159 & 1.218 & 1.317 & 1.396 & 1.341 & 1.373 & 1.382 & 1.305 & 1.330 & 1.292 & 1.262 & 15.590 \\
\hline
\end{tabular}

Fonte: Estimativa do autor. 
A15. Consumo mensal de milho nas regiões Sul e Sudeste do Brasil, 1995 (em mil toneladas).

\begin{tabular}{|c|c|c|c|c|c|c|c|c|c|c|c|c|c|}
\hline & Jan & Fev & Mar & Abr & Mai & Jun & Jul & Ago & Set & Out & Nov & Dez & Total \\
\hline Sul & 782 & 760 & 775 & 862 & 867 & 827 & 832 & 814 & 810 & 830 & 815 & 791 & 9.765 \\
\hline RS & 226 & 231 & 222 & 252 & 234 & 233 & 241 & 238 & 233 & 241 & 240 & 224 & 2.816 \\
\hline PR & 317 & 311 & 326 & 343 & 350 & 351 & 344 & 328 & 333 & 339 & 334 & 327 & 4.000 \\
\hline SC & 240 & 218 & 227 & 267 & 283 & 243 & 248 & 249 & 244 & 250 & 241 & 240 & 2.949 \\
\hline Sudeste & 567 & 532 & 568 & 567 & 653 & 645 & 671 & 682 & 595 & 608 & 577 & 540 & 7.203 \\
\hline $\mathrm{SP}$ & 369 & 348 & 367 & 363 & 413 & 403 & 419 & 427 & 375 & 379 & 371 & 352 & 4.585 \\
\hline MG & 146 & 139 & 154 & 155 & 186 & 188 & 193 & 196 & 164 & 164 & 151 & 123 & 1.959 \\
\hline RJ & 33 & 28 & 28 & 31 & 33 & 32 & 37 & 37 & 35 & 44 & 35 & 42 & 414 \\
\hline ES & 18 & 17 & 19 & 19 & 21 & 21 & 22 & 22 & 21 & 21 & 20 & 23 & 244 \\
\hline Total & 1.349 & 1.293 & 1.342 & 1.429 & 1.520 & 1.472 & 1.503 & 1.496 & 1.404 & 1.437 & 1.392 & 1.331 & 16.968 \\
\hline
\end{tabular}

Fonte: Estimativa do autor.

A16. Consumo mensal de milho nas regiões Sul e Sudeste do Brasil, 1996 (em mil toneladas).

\begin{tabular}{|c|c|c|c|c|c|c|c|c|c|c|c|c|c|}
\hline & Jan & Fev & Mar & $A b r$ & Mai & Jun & Jul & Ago & Set & Out & Nov & Dez & Total \\
\hline Sul & 832 & 826 & 833 & 934 & 933 & 880 & 890 & 865 & 853 & 870 & 834 & 804 & 10.354 \\
\hline RS & 246 & 253 & 247 & 278 & 251 & 250 & 258 & 250 & 246 & 254 & 241 & 226 & 3.001 \\
\hline PR & 336 & 335 & 344 & 366 & 374 & 368 & 366 & 351 & 353 & 357 & 347 & 334 & 4.232 \\
\hline SC & 250 & 238 & 242 & 291 & 307 & 262 & 266 & 264 & 254 & 259 & 245 & 244 & 3.121 \\
\hline Sudeste & 580 & 553 & 576 & 578 & 685 & 661 & 680 & 692 & 580 & 592 & 566 & 537 & 7.279 \\
\hline $\mathrm{SP}$ & 374 & 353 & 365 & 364 & 432 & 414 & 425 & 431 & 363 & 370 & 365 & 349 & 4.604 \\
\hline MG & 151 & 147 & 159 & 162 & 194 & 189 & 196 & 201 & 163 & 159 & 149 & 126 & 1.997 \\
\hline RJ & 36 & 33 & 33 & 33 & 37 & 36 & 37 & 38 & 34 & 45 & 32 & 39 & 432 \\
\hline ES & 20 & 19 & 19 & 19 & 22 & 22 & 22 & 22 & 19 & 19 & 20 & 23 & 247 \\
\hline Total & 1.413 & 1.379 & 1.409 & 1.512 & 1.618 & 1.540 & 1.570 & 1.557 & 1.433 & 1.462 & 1.400 & 1.341 & 17.633 \\
\hline
\end{tabular}

Fonte: Estimativa do autor. 
A17. Consumo mensal de milho nas regiões Sul e Sudeste do Brasil, 1997 (em mil toneladas).

\begin{tabular}{|c|c|c|c|c|c|c|c|c|c|c|c|c|c|}
\hline & Jan & Fev & Mar & Abr & Mai & Jun & Jul & Ago & Set & Out & Nov & Dez & Total \\
\hline Sul & 874 & 844 & 850 & 964 & 969 & 925 & 932 & 907 & 903 & 925 & 892 & 866 & 10.851 \\
\hline RS & 254 & 257 & 249 & 287 & 261 & 263 & 272 & 263 & 259 & 268 & 264 & 249 & 3.145 \\
\hline PR & 348 & 335 & 344 & 374 & 386 & 379 & 375 & 360 & 365 & 370 & 357 & 345 & 4.337 \\
\hline SC & 273 & 252 & 257 & 303 & 322 & 283 & 285 & 284 & 279 & 287 & 272 & 272 & 3.370 \\
\hline Sudeste & 596 & 564 & 607 & 622 & 739 & 714 & 736 & 752 & 633 & 660 & 607 & 569 & 7.799 \\
\hline $\mathrm{SP}$ & 383 & 366 & 394 & 397 & 468 & 446 & 460 & 469 & 394 & 400 & 383 & 366 & 4.924 \\
\hline MG & 158 & 148 & 160 & 172 & 210 & 209 & 216 & 221 & 183 & 186 & 171 & 141 & 2.175 \\
\hline RJ & 35 & 32 & 32 & 33 & 37 & 37 & 37 & 37 & 35 & 52 & 33 & 38 & 438 \\
\hline ES & 21 & 19 & 20 & 20 & 23 & 23 & 23 & 24 & 22 & 22 & 21 & 24 & 262 \\
\hline Total & 1.470 & 1.408 & 1.457 & 1.586 & 1.708 & 1.638 & 1.669 & 1.660 & 1.536 & 1.585 & 1.499 & 1.435 & 18.651 \\
\hline
\end{tabular}

Fonte: Estimativa do autor.

A18. Consumo mensal de milho nas regiões Sul e Sudeste do Brasil, 1998 (em mil toneladas).

\begin{tabular}{|c|c|c|c|c|c|c|c|c|c|c|c|c|c|}
\hline & Jan & Fev & Mar & Abr & Mai & Jun & Jul & Ago & Set & Out & Nov & Dez & Total \\
\hline Sul & 906 & 877 & 891 & 994 & 992 & 949 & 957 & 929 & 929 & 952 & 923 & 904 & 11.202 \\
\hline RS & 274 & 272 & 267 & 308 & 284 & 283 & 288 & 275 & 269 & 276 & 272 & 262 & 3.331 \\
\hline PR & 352 & 344 & 355 & 375 & 380 & 379 & 378 & 372 & 380 & 388 & 377 & 365 & 4.445 \\
\hline SC & 280 & 260 & 269 & 311 & 327 & 287 & 291 & 283 & 279 & 289 & 274 & 277 & 3.426 \\
\hline Sudeste & 612 & 560 & 598 & 614 & 722 & 696 & 720 & 736 & 628 & 655 & 615 & 581 & 7.739 \\
\hline $\mathrm{SP}$ & 387 & 352 & 371 & 378 & 445 & 423 & 438 & 446 & 379 & 388 & 380 & 364 & 4.752 \\
\hline MG & 168 & 159 & 175 & 184 & 219 & 216 & 223 & 229 & 194 & 196 & 183 & 155 & 2.305 \\
\hline RJ & 32 & 29 & 30 & 30 & 34 & 33 & 35 & 36 & 33 & 49 & 31 & 37 & 411 \\
\hline ES & 21 & 20 & 21 & 22 & 24 & 23 & 24 & 25 & 23 & 22 & 21 & 25 & 271 \\
\hline Total & 1.518 & 1.437 & 1.489 & 1.608 & 1.714 & 1.645 & 1.677 & 1.666 & 1.557 & 1.607 & 1.538 & 1.485 & 18.941 \\
\hline
\end{tabular}

Fonte: Estimativa do autor. 


\section{ANEXO B - Déficts e excedentes de milho no estado do Rio Grande do Sul, Paraná, Santa Catarina, São Paulo, Minas Gerais, Rio de Janeiro e Espirito do Santo, 1990-1998.}

B1. Déficits e excedentes de milho no estado do Rio Grande do Sul, 1990-1998 (em mil toneladas).

\begin{tabular}{rrrrrrrrrrrrrr}
\hline ANO & Jan & Fev & Mar & Abr & Mai & Jun & Jul & Ago & Set & Out & Nov & Dez & Jan \\
\hline 1990 & 245 & 593 & 1.434 & 2.078 & 2.457 & 2.627 & 2.475 & 2.327 & 2.182 & 2.033 & 1.886 & 1.748 & \\
1991 & & 52 & 358 & 549 & 602 & 548 & 325 & 97 & -124 & -229 & -224 & -211 & 368 \\
1992 & 368 & 874 & 2.069 & 2.994 & 3.543 & 3.797 & 3.601 & 3.411 & 3.224 & 3.033 & 2.851 & 2.681 & \\
1993 & 264 & 650 & 1.608 & 2.337 & 2.758 & 2.936 & 2.742 & 2.550 & 2.362 & 2.168 & 1.977 & 1.797 & \\
1994 & & 391 & 1.371 & 2.113 & 2.535 & 2.708 & 2.493 & 2.276 & 2.064 & 1.845 & 1.629 & 1.424 & 1.776 \\
1995 & & 503 & 1.750 & 2.705 & 3.258 & 3.497 & 3.256 & 3.018 & 2.785 & 2.544 & 2.304 & 2.080 & 2.122 \\
1996 & & 114 & 601 & 926 & 1.068 & 1.054 & 796 & 546 & 300 & 46 & -196 & -422 & -277 \\
1997 & 144 & 395 & 1.160 & 1.706 & 1.989 & 2.052 & 1.780 & 1.517 & 1.258 & 990 & 726 & 477 & \\
1998 & 159 & 438 & 1.272 & 1.869 & 2.175 & 2.246 & 1.958 & 1.683 & 1.414 & 1.138 & 866 & 604 & \\
\hline
\end{tabular}

Fonte: Estimativa do autor.

B2. Déficits e excedentes de milho no estado do Paraná, 1990-1998 (em mil toneladas).

\begin{tabular}{rrrrrrrrrrrrr}
\hline ANO & Fev & Mar & Abr & Mai & Jun & Jul & Ago & Set & Out & Nov & Dez & Jan \\
\hline $1990 / 91$ & 684 & 1.591 & 2.157 & 2.257 & 2.165 & 2.433 & 2.664 & 2.712 & 2.458 & 2.211 & 1.973 & 1.810 \\
$1991 / 92$ & 644 & 1.491 & 2.015 & 2.094 & 1.995 & 2.236 & 2.434 & 2.463 & 2.208 & 1.959 & 1.721 & 1.539 \\
$1992 / 93$ & 1.012 & 2.341 & 3.196 & 3.396 & 3.322 & 3.751 & 4.123 & 4.237 & 3.929 & 3.633 & 3.342 & 3.152 \\
$1993 / 94$ & 1.181 & 2.713 & 3.710 & 3.972 & 3.925 & 4.446 & 4.904 & 5.073 & 4.767 & 4.468 & 4.175 & 3.974 \\
$1994 / 95$ & 1.156 & 2.663 & 3.636 & 3.871 & 3.802 & 4.300 & 4.733 & 4.877 & 4.550 & 4.232 & 3.920 & 3.717 \\
$1995 / 96$ & 1.289 & 2.964 & 4.050 & 4.323 & 4.256 & 4.816 & 5.314 & 5.498 & 5.159 & 4.825 & 4.499 & 4.264 \\
$1996 / 97$ & 1.077 & 2.499 & 3.394 & 3.569 & 3.452 & 3.883 & 4.261 & 4.364 & 4.007 & 3.660 & 3.326 & 3.076 \\
$1997 / 98$ & 1.045 & 2.427 & 3.285 & 3.437 & 3.302 & 3.706 & 4.059 & 4.139 & 3.769 & 3.413 & 3.068 & 2.814 \\
$1998 / 99$ & 1.032 & 2.398 & 3.253 & 3.408 & 3.274 & 3.673 & 4.012 & 4.076 & 3.689 & 3.311 & 2.947 & 2.636 \\
\hline
\end{tabular}

Fonte: Estimativa do autor. 
B3. Déficits e excedentes de milho no estado de Santa Catarina, 1990-1998 (em mil toneladas).

\begin{tabular}{crrrrrrrrrrrrrr}
\hline ANO & Jan & Fev & Mar & Abr & Mai & Jun & Jul & Ago & Set & Out & Nov & Dez & Jan & Fev \\
\hline 1990 & 66 & 332 & 733 & 1.003 & 1.219 & 1.277 & 1.093 & 907 & 727 & 547 & 376 & 205 & & \\
$1991 / 92$ & & & 62 & 28 & -45 & -140 & -283 & -292 & -287 & -293 & -276 & -282 & 90 & 415 \\
1992 & 90 & 415 & 902 & 1.232 & 1.496 & 1.565 & 1.335 & 1.106 & 876 & 642 & 422 & 201 & & \\
1993 & 74 & 407 & 901 & 1.246 & 1.525 & 1.610 & 1.402 & 1.192 & 984 & 773 & 571 & 363 & & \\
$1994 / 95$ & & 340 & 843 & 1.182 & 1.451 & 1.523 & 1.298 & 1.070 & 845 & 616 & 394 & 163 & 247 & \\
$1995 / 96$ & 365 & 915 & 1.296 & 1.596 & 1.676 & 1.429 & 1.180 & 936 & 686 & 446 & 205 & 162 & -28 & \\
$1996 / 97$ & 135 & 389 & 512 & 577 & 523 & 257 & -7 & -254 & -259 & -245 & -244 & -28 \\
$1997 / 98$ & 188 & 517 & 703 & 820 & 782 & 497 & 213 & -66 & -287 & -272 & -272 & -51 & \\
$1998 / 99$ & 152 & 433 & 580 & 665 & 607 & 316 & 33 & -247 & -289 & -274 & -277 & -53 & \\
\hline
\end{tabular}

Fonte: Estimativa do autor.

B4. Déficits e excedentes de milho no estado de São Paulo, 1990-1998 (em mil toneladas).

\begin{tabular}{crrrrrrrrrrrr}
\hline ANO & Mar & Abr & Mai & Jun & Jul & Ago & Set & Out & Nov & Dez & Jan & Fev \\
\hline $1990 / 91$ & 251 & 662 & 972 & 871 & 924 & 715 & 438 & 151 & -133 & -262 & -273 & -57 \\
$1991 / 92$ & 482 & 1.201 & 1.762 & 1.716 & 1.895 & 1.671 & 1.383 & 1.085 & 755 & 448 & 138 & 49 \\
$1992 / 93$ & 466 & 1.173 & 1.736 & 1.692 & 1.884 & 1.691 & 1.388 & 1.074 & 773 & 482 & 162 & 48 \\
$1993 / 94$ & 377 & 967 & 1.429 & 1.349 & 1.481 & 1.263 & 949 & 617 & 293 & -13 & -329 & -145 \\
$1994 / 95$ & 280 & 745 & 1.079 & 935 & 974 & 709 & 372 & 24 & -323 & -338 & -369 & -134 \\
$1995 / 96$ & 427 & 1.103 & 1.617 & 1.509 & 1.638 & 1.369 & 1.003 & 624 & 253 & -98 & -374 & -172 \\
$1996 / 97$ & 309 & 828 & 1.182 & 1.019 & 1.059 & 763 & 407 & 38 & -327 & -349 & -383 & -166 \\
$1997 / 98$ & 350 & 926 & 1.325 & 1.156 & 1.210 & 889 & 504 & 104 & -279 & -366 & -387 & -165 \\
$1998 / 99$ & 324 & 855 & 1.221 & 1.057 & 1.099 & 791 & 421 & 33 & -347 & -364 & -403 & -225 \\
\hline
\end{tabular}

Fonte: Estimativa do autor.

B5. Déficits e excedentes de milho no estado de Minas Gerais, 1990-1998 (em mil toneladas).

\begin{tabular}{crrrrrrrrrrrr}
\hline ANO & Mar & Abr & Mai & Jun & Jul & Ago & Set & Out & Nov & Dez & Jan & Fev \\
\hline $1990 / 91$ & 190 & 875 & 1.342 & 1.507 & 1.369 & 1.246 & 1.134 & 1.008 & 891 & 796 & 666 & 544 \\
$1991 / 92$ & 355 & 1.520 & 2.327 & 2.645 & 2.466 & 2.305 & 2.155 & 1.985 & 1.831 & 1.706 & 1.567 & 1.407 \\
$1992 / 93$ & 325 & 1.477 & 2.275 & 2.577 & 2.376 & 2.201 & 2.035 & 1.853 & 1.684 & 1.542 & 1.383 & 1.267 \\
$1993 / 94$ & 374 & 1.578 & 2.424 & 2.770 & 2.615 & 2.486 & 2.362 & 2.224 & 2.095 & 1.990 & 1.865 & 1.745 \\
$1994 / 95$ & 355 & 1.516 & 2.323 & 2.645 & 2.477 & 2.335 & 2.204 & 2.054 & 1.913 & 1.797 & 1.651 & 1.512 \\
$1995 / 96$ & 341 & 1.505 & 2.308 & 2.614 & 2.428 & 2.268 & 2.122 & 1.959 & 1.808 & 1.685 & 1.534 & 1.386 \\
$1996 / 97$ & 281 & 1.292 & 1.978 & 2.228 & 2.038 & 1.869 & 1.721 & 1.563 & 1.414 & 1.288 & 1.130 & 983 \\
$1997 / 98$ & 357 & 1.564 & 2.389 & 2.697 & 2.488 & 2.304 & 2.140 & 1.954 & 1.783 & 1.642 & 1.474 & 1.315 \\
$1998 / 99$ & 315 & 1.438 & 2.199 & 2.473 & 2.256 & 2.063 & 1.887 & 1.691 & 1.508 & 1.353 & 1.161 & 982 \\
\hline
\end{tabular}

Fonte: Estimativa do autor. 
B6. Déficits e excedentes de milho no estado de Rio de Janeiro, 1990-1998 (em mil toneladas).

\begin{tabular}{|c|c|c|c|c|c|c|c|c|c|c|c|c|}
\hline ANO & Mar & Abr & Mai & Jun & Jul & Ago & Set & Out & Nov & Dez & Jan & Fev \\
\hline $1990 / 91$ & -19 & -21 & -28 & -29 & -33 & -35 & -31 & -35 & -30 & -36 & -44 & -32 \\
\hline $1991 / 92$ & -25 & -28 & -42 & -44 & -49 & -54 & -52 & -58 & -50 & -56 & -29 & -12 \\
\hline 1992/93 & -2 & -3 & -13 & -16 & -22 & -21 & -18 & -24 & -17 & -19 & -22 & -19 \\
\hline $1993 / 94$ & -8 & -11 & -23 & -27 & -34 & -34 & -31 & -39 & -31 & -36 & -31 & -23 \\
\hline 1994/95 & -15 & -18 & -26 & -27 & -34 & -36 & -33 & -40 & -31 & -38 & -33 & -25 \\
\hline $1995 / 96$ & -19 & -23 & -28 & -29 & -37 & -37 & -35 & -44 & -35 & -42 & -36 & -28 \\
\hline $1996 / 97$ & -22 & -23 & -31 & -33 & -37 & -38 & -34 & -45 & -32 & -39 & -35 & -27 \\
\hline $1997 / 98$ & -21 & -23 & -32 & -33 & -37 & -37 & -35 & -52 & -33 & -38 & -32 & -25 \\
\hline $1998 / 99$ & -20 & -21 & -29 & -30 & -35 & -36 & -33 & -49 & -31 & -37 & -33 & -26 \\
\hline
\end{tabular}

Fonte: Estimativa do autor.

B7. Déficits e excedentes de milho no estado do Espirito Santo, 1990-1998 (em mil toneladas).

\begin{tabular}{crrrrrrrrrrrr}
\hline ANO & Fev & Mar & Abr & Mai & Jun & Jul & Ago & Set & Out & Nov & Dez & Jan \\
\hline $1990 / 91$ & 37 & 84 & 108 & 107 & 89 & 70 & 51 & 34 & 18 & 2 & -15 & -18 \\
$1991 / 92$ & 68 & 155 & 202 & 208 & 187 & 165 & 141 & 120 & 98 & 77 & 54 & 37 \\
$1992 / 93$ & 54 & 125 & 161 & 163 & 142 & 120 & 98 & 78 & 60 & 42 & 21 & 4 \\
$1993 / 94$ & 64 & 145 & 189 & 196 & 178 & 159 & 140 & 123 & 106 & 91 & 71 & 55 \\
$1994 / 95$ & 47 & 106 & 137 & 138 & 119 & 99 & 79 & 62 & 45 & 27 & 6 & -12 \\
$1995 / 96$ & 15 & 36 & 42 & 32 & 11 & -11 & -22 & -21 & -21 & -20 & -23 & -20 \\
$1996 / 97$ & 18 & 45 & 55 & 45 & 24 & 1 & -21 & -19 & -19 & -20 & -23 & -21 \\
$1997 / 98$ & 24 & 56 & 68 & 59 & 36 & 13 & -11 & -22 & -22 & -21 & -24 & -21 \\
$1998 / 99$ & 15 & 36 & 40 & 28 & 5 & -20 & -25 & -23 & -22 & -21 & -25 & -23 \\
\hline
\end{tabular}

Fonte: Estimativa do autor. 


\section{ANEXO C - Ritmo de colheita da safra de milho no Centro-Sul}

C1. Ritmo de colheita da safra de milho no Centro-Sul.

\begin{tabular}{|c|c|c|c|c|c|c|c|c|c|c|c|c|}
\hline & Jan & Fev & Mar & Abr & Mai & Jun & Jul & Ago & Set & Out & Nov & Dez \\
\hline Sul & $5 \%$ & $18 \%$ & $25 \%$ & $19 \%$ & $11 \%$ & $6 \%$ & $6 \%$ & $6 \%$ & $4 \%$ & $0 \%$ & $0 \%$ & $0 \%$ \\
\hline RS & $11 \%$ & $14 \%$ & $28 \%$ & $23 \%$ & $15 \%$ & $9 \%$ & $0 \%$ & $0 \%$ & $0 \%$ & $0 \%$ & $0 \%$ & $0 \%$ \\
\hline PR & $1 \%$ & $19 \%$ & $24 \%$ & $17 \%$ & $8 \%$ & $3 \%$ & $11 \%$ & $10 \%$ & $6 \%$ & $0 \%$ & $0 \%$ & $0 \%$ \\
\hline SC & $10 \%$ & $18 \%$ & $24 \%$ & $20 \%$ & $18 \%$ & $10 \%$ & $0 \%$ & $0 \%$ & $0 \%$ & $0 \%$ & $0 \%$ & $0 \%$ \\
\hline Sudeste & $0 \%$ & $3 \%$ & $18 \%$ & $33 \%$ & $26 \%$ & $11 \%$ & $7 \%$ & $2 \%$ & $0 \%$ & $0 \%$ & $0 \%$ & $0 \%$ \\
\hline $\mathrm{SP}$ & $0 \%$ & $5 \%$ & $20 \%$ & $26 \%$ & $23 \%$ & $7 \%$ & $14 \%$ & $4 \%$ & $0 \%$ & $0 \%$ & $0 \%$ & $0 \%$ \\
\hline MG & $0 \%$ & $0 \%$ & $15 \%$ & $39 \%$ & $29 \%$ & $15 \%$ & $0 \%$ & $1 \%$ & $1 \%$ & $0 \%$ & $0 \%$ & $0 \%$ \\
\hline RJ & $0 \%$ & $13 \%$ & $32 \%$ & $29 \%$ & $16 \%$ & $10 \%$ & $0 \%$ & $0 \%$ & $0 \%$ & $0 \%$ & $0 \%$ & $0 \%$ \\
\hline ES & $0 \%$ & $30 \%$ & $37 \%$ & $23 \%$ & $10 \%$ & $0 \%$ & $0 \%$ & $0 \%$ & $0 \%$ & $0 \%$ & $0 \%$ & $0 \%$ \\
\hline Centro-Oeste & $0 \%$ & $14 \%$ & $30 \%$ & $15 \%$ & $8 \%$ & $11 \%$ & $13 \%$ & $7 \%$ & $2 \%$ & $0 \%$ & $0 \%$ & $0 \%$ \\
\hline GO & $0 \%$ & $19 \%$ & $33 \%$ & $15 \%$ & $10 \%$ & $13 \%$ & $8 \%$ & $2 \%$ & $0 \%$ & $0 \%$ & $0 \%$ & $0 \%$ \\
\hline MT & $0 \%$ & $6 \%$ & $23 \%$ & $14 \%$ & $12 \%$ & $20 \%$ & $24 \%$ & $1 \%$ & $0 \%$ & $0 \%$ & $0 \%$ & $0 \%$ \\
\hline MS & $2 \%$ & $10 \%$ & $30 \%$ & $13 \%$ & $2 \%$ & $2 \%$ & $13 \%$ & $22 \%$ & $6 \%$ & $0 \%$ & $0 \%$ & $0 \%$ \\
\hline DF & $0 \%$ & $4 \%$ & $31 \%$ & $31 \%$ & $19 \%$ & $8 \%$ & $6 \%$ & $1 \%$ & $0 \%$ & $0 \%$ & $0 \%$ & $0 \%$ \\
\hline
\end{tabular}

Fonte: CONAB, 1998. 


\section{ANEXO D - Variação estacional do preço do milho: Rio Grande do Sul, Paraná, Santa Catarina, São Paulo e Minas Gerais, 1990-1998.}

D1. Variação estacional, índice sazonal e índice de irregularidade do preço do milho no estado do Rio Grande do Sul. Índice estacional obtido pelo método da média geométrica móvel, utilizando preços fornecidos pela CONAB.

\begin{tabular}{|c|c|c|c|c|c|c|c|c|c|c|c|}
\hline Mês & 1990 & 1991 & 1992 & 1993 & 1994 & 1995 & 1996 & 1997 & 1998 & $\begin{array}{c}\text { Índice } \\
\text { saz. }\end{array}$ & $\begin{array}{l}\text { Índice } \\
\text { irreg. }\end{array}$ \\
\hline Jan & & 93,3 & 99,1 & 113,8 & 112,5 & 106,4 & 110,1 & 93,7 & 99,2 & 103,0 & 1,083 \\
\hline Fev & & 82,5 & 96,2 & 101,1 & 98,5 & 97,7 & 99,2 & 87,6 & 98,2 & 94,7 & 1,074 \\
\hline Mar & $\ldots$ & 94,5 & 83,9 & 90,6 & 89 , & 87,7 & 97,2 & & 97,0 & 90,8 & 1,053 \\
\hline $\mathrm{Abr}$ & & 10 & 76,7 & & 87 & 87, & & & & 90,7 & 1,097 \\
\hline Mai & $\ldots$ & & 87, & 94 & 92 & 87,4 & & & & 97,5 & 1,100 \\
\hline Jun & & & 102,2 & 86 , & 95 & 95,0 & & 99,6 & 101,2 & 99,2 & 1,081 \\
\hline Jul & 113,0 & 102 & 98,5 & 90,1 & 105 & 92,8 & 105 & 99,8 & 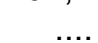 & 100,4 & 1,076 \\
\hline Ago & & & 95,4 & 103,2 & 103,9 & 99,8 & 107,6 & 99 , &. & 101,6 & 1,050 \\
\hline Set & 107,7 & 100,7 & 101,0 & 104,7 & 104,5 & 99,4 & 109,8 & 97,8 & & 102,9 & 1,041 \\
\hline Out & 100,3 & 113,3 & 108,9 & 106,6 & 104,3 & 97,1 & 111,9 & & .... & 105,5 & 1,054 \\
\hline Nov & & 125,4 & 109,5 & 111,9 & 103 & 101,7 & & & $\ldots$ & 107,3 & 1,074 \\
\hline Dez & 107,5 & 99,9 & 118,9 & 121,5 & 115,0 & 106,8 & 100,6 & 101,0 & & 108,4 & 1,081 \\
\hline
\end{tabular}

Fonte: Estimativa do autor.

D2. Variação estacional, índice sazonal e índice de irregularidade do preço do milho no estado do Paraná. Índice estacional obtido pelo método da média geométrica móvel, utilizando preços fornecidos pela CONAB.

\begin{tabular}{rrrrrrrrrrrr}
\hline Mês & 1990 & 1991 & 1992 & 1993 & 1994 & 1995 & 1996 & 1997 & 1998 & $\begin{array}{r}\text { Índice } \\
\text { saz. }\end{array}$ & $\begin{array}{l}\text { Índice } \\
\text { irreg. }\end{array}$ \\
\hline Jan & $\ldots$. & 100,0 & 90,8 & 107,4 & 111,4 & 110,4 & 107,7 & 87,1 & 104,4 & 100,9 & 1,093 \\
Fev & $\ldots$. & 94,5 & 103,0 & 105,2 & 98,3 & 110,0 & 97,6 & 89,1 & 103,1 & 98,4 & 1,056 \\
Mar & $\ldots$ & 92,8 & 95,9 & 89,6 & 88,5 & 88,7 & 95,2 & 90,2 & 101,9 & 92,5 & 1,050 \\
Abr & $\ldots$ & 97,9 & 87,8 & 88,5 & 89,7 & 87,9 & 100,9 & 91,7 & 101,6 & 92,8 & 1,065 \\
Mai & $\ldots$. & 109,9 & 86,4 & 89,9 & 95,4 & 88,3 & 106,0 & 102,9 & 100,7 & 96,8 & 1,094 \\
Jun & $\ldots$. & 101,3 & 95,9 & 93,5 & 95,4 & 97,1 & 104,4 & 103,9 & 99,5 & 98,5 & 1,042 \\
Jul & 105,7 & 97,5 & 95,2 & 94,4 & 98,8 & 95,3 & 104,1 & 94,5 & $\ldots$ & 97,8 & 1,045 \\
Ago & 110,3 & 94,7 & 94,8 & 107,8 & 97,6 & 94,1 & 105,7 & 93,7 & $\ldots$ & 99,3 & 1,071 \\
Set & 110,1 & 98,8 & 101,6 & 107,5 & 98,1 & 94,1 & 107,1 & 101,3 & $\ldots$. & 101,9 & 1,055 \\
Out & 101,2 & 104,9 & 109,7 & 105,2 & 108,8 & 102,2 & 117,4 & 99,9 & $\ldots$ & 105,7 & 1,054 \\
Nov & 100,1 & 119,1 & 109,0 & 110,1 & 108,4 & 107,9 & 111,1 & 98,3 & $\ldots$ & 107,5 & 1,062 \\
Dez & 116,2 & 110,6 & 120,0 & 117,9 & 110,0 & 104,8 & 103,7 & 97,3 & $\ldots$. & 109,5 & 1,075 \\
\hline
\end{tabular}

Fonte: Estimativa do autor. 
D3. Variação estacional, índice sazonal e índice de irregularidade do preço do milho no estado do Santa Catarina. Índice estacional obtido pelo método da média geométrica móvel, utilizando preços fornecidos pela CONAB.

\begin{tabular}{|c|c|c|c|c|c|c|c|c|c|c|c|}
\hline Mês & 1990 & 1991 & 1992 & 1993 & 1994 & 1995 & 1996 & 1997 & 1998 & $\begin{array}{r}\text { Índice } \\
\text { saz. }\end{array}$ & $\begin{array}{l}\text { İndice } \\
\text { irreg. }\end{array}$ \\
\hline Jan & & 94,4 & 107,1 & 113,9 & 104,4 & 112,4 & 105,8 & 88,9 & 102,6 & 103,0 & 1,088 \\
\hline Fev & $\ldots$ & 83,3 & 95,9 & 99,8 & 97,9 & 82,2 & 94,4 & 83,0 & 101,5 & 1,6 & 093 \\
\hline Mar & & 90,2 & 88,9 & 89,5 & 92,2 & 81,7 & 92,1 & 84,3 & 100,4 & 89,5 & 064 \\
\hline $\mathrm{Abr}$ & 形 & 102,4 & 78,6 & 95,6 & 90,9 & 90,4 & 97,3 & 94,5 & 100,1 & 93,1 & 086 \\
\hline Mai & . & 107,0 & 83,5 & 98,8 & 101,2 & 100,5 & 109,1 & 105,0 & 106,7 & 100,8 & 089 \\
\hline Jun & $\ldots$ & 100,4 & 100,4 & 89,7 & 97,1 & 98,4 & 107,5 & 96,8 & 97,7 & 98,0 & 1,052 \\
\hline Jul & 110,1 & 95,3 & 85,8 & 92,5 & 99,1 & 96,3 & 107,5 & 96,6 & $\ldots$ & 97,3 & 1,083 \\
\hline Ago & 115,8 & 99,9 & 95,1 & 103,9 & 98,6 & 94,0 & 109,9 & 95,4 & & 100,9 & 1,078 \\
\hline Set & 104,9 & 99,5 & 112,2 & 109,0 & 100,7 & 102,1 & 112,3 & 101,7 & & 104,8 & 1,050 \\
\hline Out & & & 106,9 & & 101,2 & 9,6 & & 100,0 & .... & 104,5 & 1,071 \\
\hline Nov & & & 111,2 & & & 104,8 & & 98,2 & 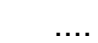 & 108,4 & 1,055 \\
\hline Dez & 128,6 & 112,1 & 111,4 & 116,1 & 111,9 & 102,0 & 103,4 & 104,6 & . & 110,3 & 1,078 \\
\hline
\end{tabular}

Fonte: Estimativa do autor.

D4. Variação estacional, índice sazonal e índice de irregularidade do preço do milho no estado do São Paulo. Índice estacional obtido pelo método da média geométrica móvel, utilizando preços fornecidos pela CONAB.

\begin{tabular}{rrrrrrrrrrrr}
\hline Mês & 1990 & 1991 & 1992 & 1993 & 1994 & 1995 & 1996 & 1997 & 1998 & $\begin{array}{r}\text { Índice } \\
\text { saz. }\end{array}$ & $\begin{array}{l}\text { Índice } \\
\text { irreg. }\end{array}$ \\
\hline Jan & $\ldots$. & 109,4 & 132,0 & 124,3 & 108,8 & 113,3 & 113,4 & 97,3 & 109,7 & 112,6 & 1,096 \\
Fev & $\ldots$ & 94,4 & 114,0 & 94,2 & 86,4 & 106,0 & 103,1 & 90,1 & 101,7 & 97,9 & 1,096 \\
Mar & $\ldots$ & 82,5 & 88,4 & 85,2 & 86,8 & 88,5 & 93,7 & 90,7 & 101,0 & 89,1 & 1,064 \\
Abr & $\ldots$ & 92,0 & 86,6 & 63,8 & 91,8 & 88,3 & 92,3 & 91,6 & 100,7 & 87,3 & 1,146 \\
Mai & $\ldots$ & 101,1 & 82,9 & 92,3 & 90,7 & 80,6 & 98,1 & 92,2 & 100,3 & 91,6 & 1,087 \\
Jun & $\ldots$ & 94,8 & 83,2 & 90,9 & 92,8 & 88,9 & 97,3 & 91,8 & 100,2 & 91,9 & 1,059 \\
Jul & 103,0 & 92,0 & 81,3 & 102,8 & 104,0 & 88,0 & 97,6 & 99,4 & $\ldots$ & 95,3 & 1,092 \\
Ago & 116,8 & 102,1 & 102,0 & 116,7 & 93,1 & 96,0 & 107,3 & 98,0 & $\ldots$ & 103,2 & 1,089 \\
Set & 110,6 & 97,8 & 115,7 & 116,1 & 101,1 & 97,1 & 109,1 & 96,0 & $\ldots$ & 104,7 & 1,083 \\
Out & 104,4 & 97,3 & 116,5 & 100,3 & 109,3 & 105,1 & 110,5 & 102,0 & $\ldots$ & 105,0 & 1,060 \\
Nov & 113,9 & 113,0 & 120,1 & 120,9 & 117,6 & 110,8 & 112,2 & 107,1 & $\ldots$ & 113,9 & 1,042 \\
Dez & 118,4 & 104,8 & 123,2 & 121,3 & 120,2 & 108,7 & 105,4 & 104,6 & $\ldots$ & 112,6 & 1,075 \\
\hline
\end{tabular}

Fonte: Estimativa do autor. 
D5. Variação estacional, índice sazonal e índice de irregularidade do preço do milho no estado de Minas Gerais. Índice estacional obtido pelo método da média geométrica móvel, utilizando preços fornecidos pela CONAB.

\begin{tabular}{|c|c|c|c|c|c|c|c|c|c|c|c|}
\hline Mês & 1990 & 1991 & 1992 & 1993 & 1994 & 1995 & 1996 & 1997 & 1998 & $\begin{array}{r}\text { Índice } \\
\text { saz. }\end{array}$ & $\begin{array}{l}\text { Indice } \\
\text { irreg. }\end{array}$ \\
\hline Jan & & 115,4 & 136,6 & 122,3 & 119,5 & 112,3 & 112,4 & 106,3 & 107,8 & 115,6 & 1,084 \\
\hline Fev & $\ldots$ & 108,7 & 132,4 & 101,6 & 103,9 & 113,0 & 110,2 & 100,2 & 106,8 & 108,6 & 092 \\
\hline Mar & $\ldots$ & 94,5 & 89,9 & 99,7 & 85,1 & 98,8 & & 93,6 & 105,8 & 94,6 & 069 \\
\hline Abr & $\cdots$ & 92,5 & 79,9 & 93,6 & 93,7 & 91,4 & 94,7 & 94,4 & 99,3 & 91,8 & 065 \\
\hline Mai & … & 92,7 & 76,7 & 82,7 & 91,7 & 84,7 & 99,9 & 95,2 & 99,2 & 89,5 & 098 \\
\hline Jun & & 89,5 & 78,7 & 83,2 & 80,6 & 83,7 & 99,2 & 88,1 & 99,0 & 87,0 & 1,092 \\
\hline Jul & 117,7 & 83,5 & 82,7 & 84,5 & 84,9 & 82,6 & 92,5 & 95,6 & $\ldots$ & 89,4 & 1,130 \\
\hline Ago & 107,2 & 91,5 & 97,2 & 96,4 & 90,8 & 89,6 & 100,6 & 95,4 & & 95,4 & 1,061 \\
\hline Set & 109,0 & 92,7 & 109,8 & 104,2 & 127,3 & 98,6 & 102,1 & 93,9 & & 103,6 & 1,107 \\
\hline Out & & 101,0 & 109,6 & 110,7 & 103,7 & 105,9 & 103,3 & & $\ldots$ & 104,1 & 1,037 \\
\hline Nov & & & & 120,1 & 117,9 & 110,9 & 111,7 & 5,1 & ( & 112,9 & 1,047 \\
\hline Dez & 121,2 & 113,5 & 124,1 & 125,4 & 112,0 & 108,8 & 106,1 & 103,1 & $\ldots$ & 113,4 & 1,076 \\
\hline
\end{tabular}

Fonte: Estimativa do autor. 


\section{REFERÊNCIAS BIBLIOGRÁFICAS}

BARROS, J.R.M. ; PASTORE, A.C. ; RIZZIERI, J.A.B. A evolução da agricultura brasileira. In: ARAÚJO, P.F.C. ; SCHUH, G.E. Desenvolvimento da agricultura. São Paulo: Livraria Pioneira Editora. v.4, p.257-277.

BOSE, M.L.V. Cálculo de rações. In: PEIXOTO, A. M. ; MOURO, J.C. ; FARIA, V.P. Confinamento de bovinos de corte. Piracicaba: FEALQ, 1992. p.163-65. (Série Atualização em Zootecnia, 2)

COHEN, K.L. The economics of agriculture. Cambridge: James Nisbert and Company Limited ; Cambridge University Press, 1956.

DIAS, G.L.S. (Coord.). Projeto BM\&F Agrícola. São Paulo: BM\&F, 1998. 140p.

EMPRESA BRASILEIRA DE PESQUISA AGROPECUÁRIA. CENTRO NACIONAL DE PESQUISA DE SUÍNOS E AVES. Análise prospectiva do complexo agroindustrial de suínos no Brasil. Concórdia, 1992. 108p. (Documento, 26)

FUNDAÇÃO INTITUTO BRASILEIRO DE GEOGRAFIA E ESTATÍSTICA. Censo agropecuário 1995/96 (compact disc). Rio de Janeiro: IBGE, 1998.

FUNDAÇÃO INTITUTO BRASILEIRO DE GEOGRAFIA E ESTATÍSTICA. Pesquisa pecuária municipal. Rio de Janeiro: IBGE, 1999.

FUNDAÇÃO INTITUTO BRASILEIRO DE GEOGRAFIA E ESTATÍSTICA. Pesquisa trimestral de abate de animais. Rio de Janeiro: IBGE, 1999.

FUNDAÇÃO INTITUTO BRASILEIRO DE GEOGRAFIA E ESTATÍSTICA. Produção agrícola municipal. Rio de Janeiro: IBGE, 2000. 
FUNDAÇÃO INTITUTO BRASILEIRO DE GEOGRAFIA E ESTATÍSTICA Levantamento sistemático da produção agrícola. Rio de Janeiro: IBGE, 1992-1996.

GRILICHES, Z. Hybrid corn: an exploration in the economics of technological change. Econometrica, v.24, n.4, p.501-522, 1957.

HAYAMI, Y. ; RUTTAN, V.W. Preços dos fatores e mudança técnica no desenvolvimento da agricultura: Estados Unidos e Japão. In: ARAÚJO, P.C. ; SCHUH, G.E. (Ed.) Desenvolvimento da agricultura: educação, pesquisa e assistência técnica. São Paulo: Livraria Pioneira, 1975. v.2 : p.53-75.

HELFAND, S. M. ; RESENDE, G.C. Mudanças na distribuição espacial da produção de grãos, aves e suínos no Brasil: o papel do Centro-Oeste. Rio de Janeiro: Instituto de Pesquisa Econômica Aplicada - IPEA, 1998. 37p. (Texto para discussão, 611)

HOFFMANN, R. Variação estacional dos preços de produtos agropecuários no Estado de São Paulo. Piracicaba, 1969. 184p. Tese (Doutorado) - Escola Superior de Agricultura "Luiz de Queiroz", Universidade de São Paulo.

HOFFMANN, R. Estatística para economistas. 2.ed. São Paulo: Livraria Pioneira, 1991. 426p.

JANK, M.S. ; FARINA, E..M.Q. ; GALAN, V.B. O agribusiness do leite no Brasil. São Paulo: Milkbizz, 1999. 108p.

JANVRY, A. social structure and biesed technical change in Argentine agriculture. In: BISWANGER, H.P. ; RUTTAN, V.W. Induced inovations. The Johns Hopkins University Press, 1978. p.297-326.

JORGENSON, D.W. Teste de teorias alternativas de desenvolvimento em economia dualista. In: ARAÚJO, P.F.C. ; SCHUH, G.E. Desenvolvimento da agricultura: natureza do processo e modelos dualistas. São Paulo: Pioneira, 1975. v.1. cap. 2: p.137-152: modelos dualistas e o desenvolvimento agrícola.

LANGE, O. Estudo e previsão do curso da conjuntura econômica. In: Introdução à econometria. Rio de Janeiro: Fundo de Quintal, 1967. p.23-75.

LUQUE, C.A. ; CHAHAD, J.P.Z. Salário real e a oferta de alimentos básicos no Brasil. Revista de Economia Política, v.10, n.3, p.40-61, jul./set. 1990. 
MATTAR, F. N. Pesquisa de marketing. São Paulo: Atlas, 1996. 270p.

MELO, F.B.H. Padrões de instabilidade entre culturas da agricultura brasileira. Planejamento e Pesquisa Econômica, v.9, n.3, p.819-844, dez.1979.

NATIONAL RESEARCH COUNCIL. Nutrient requirements of dairy cattle. 6.ed.rev. Washington: Ed. Natl. Acad. Sci, 1988. 157p.

NATIONAL RESEARCH COUNCIL. Nutrient requirements of beef cattle. 7.ed.rev. Washington: Ed. Natl. Acad. Sci, 1996. 242p.

OWEN, W.F. A dupla pressão do processo de desenvolvimento econômico sobre a agricultura. In: ARAÚJO, P.C. ; SCHUH, G.E. (Ed.). Desenvolvimento da agricultura: natureza do processo e modelos dualistas. São Paulo: Livraria Pioneira Editora, 1975. v.1, p. 39-65.

PAIVA, R.M. Modernização e dualismo tecnológico na agricultura: uma reformulação. Pesquisa e Planejamento Econômico, v.5, n.1, p.117-162, 1975.

QUANTITATIVE MICRO SOFTWARE. Programa Econometric Views: EVIEWS Version 3.1. 1999.

REZENDE, G.C. Crescimento econômico e oferta de alimentos no Brasil. In: ENCONTRO NACIONAL DE ECONOMIA, 12., Vitória, 1985. Anais. Recife: ANPEC, 1985. p47-69.

RISSETO, V.V. A dinâmica da comercialização do milho no Brasil. Piracicaba: ESALQ. Depto. de Economia e Sociologia Rural, 1997. 42p.

SANTOS, J.P. ; MANTOVANI, E.C. Perdas de grãos na cultura do milho: pré-colheita, colheita, transporte e armazenamento. Sete Lagoas: EMBRAPA. CNPMS, 1997. 40p. (EMBRAPA-CNPMS. Circular Técnico, 24)

SCHUH, G. E. Modernização da agricultura brasileira. In: ARAÚJO, P.C. ; SCHUH, G.E. (Ed.) Desenvolvimento da agricultura: análise de política econômica. São Paulo: Livraria Pioneira Editora, 1977. v.3, p.281- 311.

SCHULTZ, T.W. Transforming tradicional agriculture. New Haven: Yale University Press, 1964. 212p. 
SOBESTIANSKY, J. ; SESTI, L.A.C. Aspectos da produtividade. In: SOBESTIANSKY, J. ; SESTI, L.A.C. ; WENTZ, I. ; SILVEIRA, P.R.S. Suinocultura intensiva: produção, manejo e saúde do rebanho. Brasília: EMBRAPA, 1998. cap. 2, p. 29-43.

VOLL, V.L. Ação do Estado e produção de subsistência numa região do Vale do Jequitinhonha. Piracicaba, 1984. 128p. Dissertação (M.S.) - Escola Superior de Agricultura "Luiz de Queiroz", Universidade de São Paulo.

WENTZ, I. ; Silveira, P.R.S.; SESTI, L.A.C. Aspectos sanitários relacionados com o reprodutor. In: SOBESTIANSKY, J. ; SESTI, L.A.C. ; WENTZ, I. ; SILVEIRA, P.R.S. Suinocultura intensiva: produção, manejo e saúde do rebanho. Brasília: EMBRAPA, 1998. cap.9, p.202. 


\section{APÊNDICES}




\section{APÊNDICE 1 - Questionários da Avicultura}

\section{Avicultura de Corte}

Nome do entrevistado:

Cargo que ocupa na empresa: produtor ( ) técnico ( ) outro( )

Endereço das propriedade:

\section{1-Frangos}

1) Qual é a idade de abate dos frangos?

2) Qual é a quantidade fornecida de ração para cada uma das fases de desenvolvimento do frango e qual o percentual de milho utilizado na ração?

3) Existe perda de ração no armazenamento ou no processo de alimentação dos animais? Quanto, em média, você estimaria essa perda?

\section{2- Matrizes em recria}

1) Qual é a idade que a matriz começa a produzir?

2) Qual é a taxa de mortalidade média nesse período?

3) Qual o consumo de ração diário por fase de desenvolvimento e qual o percentual de milho utilizado na ração?

\section{3- Galos em recria}

1) A partir de qual idade os machos são utilizados como reprodutores?

2) Qual é a taxa de mortalidade média dos galos nesse período?

3) Quantas fêmeas são disponíveis por macho?

4) Qual o consumo de ração diário por fase de desenvolvimento e qual o percentual de milho utilizado na ração? (Se for a mesma quantidade da fêmea não é necessário responder). 


\section{4 - Matrizes em produção}

1) Qual é a quantidade mensal de ovos produzidos por uma matriz ?

2) Qual é o percentual de eclosão desses ovos? Qual é o percentual de aproveitamento das fêmeas?

3) Qual é o consumo de ração diário de uma matriz e o percentual de milho utilizado na ração?

\section{5 - Estoque de galos}

1) Quantas fêmeas são disponíveis por macho?

2) Qual é o consumo de ração diário de um galo e o percentual de milho utilizado na ração? (Se for a mesma quantidade da fêmea não é necessário responder).

\section{2- Avicultura de Postura}

Nome do entrevistado:

Cargo que ocupa na empresa: produtor ( ) técnico ( ) outro( )

Endereço das propriedade:

\section{1 - Comerciais em produção}

1) Qual a quantidade de ração utilizada para 12 ovos (conversão alimentar)?

a. para aves que produzem ovos brancos:

b. para aves que produzem ovos vermelhos:

2) Qual é a participação do milho na composição da ração?

a. ovos brancos:

b. ovos vermelhos:

3) Existe perda de ração no armazenamento ou no processo de alimentação dos animais? Quanto, em média, você estimaria essa perda? 


\section{2 - Comerciais em recria}

1) A partir de qual idade as fêmeas começam a produzir ovos comerciais?

a. ovos brancos:

b. ovos vermelhos:

2) Qual o consumo de ração diário por fase de desenvolvimento e qual o percentual de milho utilizado na ração?

a. ovos brancos:

b. ovos vermelhos:

3) Qual é a taxa de mortalidade nesse período?

a. ovos brancos:

b. ovos vermelhos:

\section{3 -Estoque de matrizes}

1) Uma matriz produz quantos ovos por mês?

a. ovos brancos:

b. ovos vermelhos:

2) Qual é o percentual de eclosão dos ovos? Qual é o percentual de aproveitamento das fêmeas?

a. ovos brancos:

b. ovos vermelhos:

3) Qual é a idade média de vida das matrizes?

a. ovos brancos:

b. ovos vermelhos:

4) Qual o consumo diário de ração das matrizes e qual o percentual de milho utilizado na ração?

a. ovos brancos:

b. ovos vermelhos: 


\section{4 - Matrizes em recria}

1) Qual é a idade que a matriz começa a produzir ovos incubáveis?

a. ovos brancos:

b. ovos vermelhos:

2) Qual o consumo de ração diário por fase de desenvolvimento e qual o percentual de milho utilizado na ração?

a. ovos brancos:

b. ovos vermelhos:

3) Qual é a taxa de mortalidade média das matrizes nesse período?

a. ovos brancos:

b. ovos vermelhos:

\section{5 - Galos em recria}

1) A partir de qual idade os machos são utilizados como reprodutores?

a. ovos brancos:

b. ovos vermelhos:

2) Quantas matrizes são disponíveis por galo?

a. ovos brancos:

b. ovos vermelhos:

3) Qual é a taxa de mortalidade média dos galos nesse período?

a. ovos brancos:

b. ovos vermelhos:

4) Qual o consumo de ração diário por fase de desenvolvimento e qual o percentual de milho utilizado na ração?

a. ovos brancos:

b. ovos vermelhos: 


\section{APÊNDICE 2 - Questionário da Suinocultura}

Nome do entrevistado:

Cargo que ocupa na empresa: produtor ( ) técnico ( ) outro( )

Endereço das propriedade:

1) Qual é a idade media de abate dos suínos?

2) Qual o peso médio de abate dos suínos?

3) Qual é o rendimento da carcaça?

4) Qual é a conversão alimentar média dos animais de abate?

5) Qual o percentual de milho utilizado na ração dos suínos?

6) Qual o percentual de milho utilizado na ração das matrizes e cachaços?

7) Quando o preço do milho está alto você substitui por outro produto? Qual é esse produto e, geralmente, isso ocorre em qual época do ano?

8) Qual o número de leitões terminados /matriz/ ano?

9) Quantas matrizes são utilizadas para um cachaço?

10) Qual é o número de cabeças total do rebanho?

11) Quantos animais são abatidos por ano? 